\title{
Phenazine-Based Covalent Organic Framework Cathode Materials with High Energy and Power Densities
}

\author{
Edon Vitaku, ${ }^{1}$ Cara N. Gannett, ${ }^{2}$ Keith L. Carpenter, ${ }^{2}$ Luxi Shen, ${ }^{2}$ \\ Héctor D. Abruña, ${ }^{*, 2}$ and William R. Dichtel ${ }^{*, 1}$ \\ ${ }^{1}$ Department of Chemistry, Northwestern University, 2145 Sheridan Road, \\ Evanston, Illinois 60208, United States \\ ${ }^{2}$ Department of Chemistry and Chemical Biology, Baker Laboratory, Cornell University, \\ Ithaca, New York 14853-1301, United States
}

\section{Supplementary Information}

\begin{tabular}{|c|}
\hline Correspondence Address \\
\hline Professor William R. Dichtel \\
Department of Chemistry \\
Northwestern University \\
2045 Sheridan Road \\
Evanston, IL 60208 (USA) \\
wdichtel@northwestern.edu \\
Professor Héctor D. Abruña \\
Cornell University \\
Baker Laboratory \\
Department of Chemistry and Chemical Biology \\
hda1@ cornell.edu \\
\hline
\end{tabular}

\section{Table of Contents}

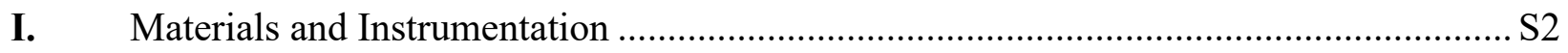

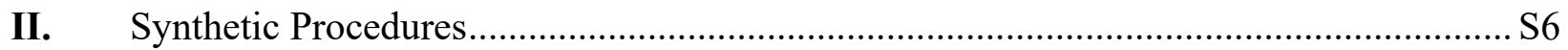

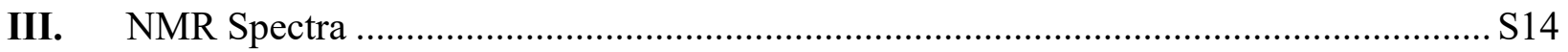

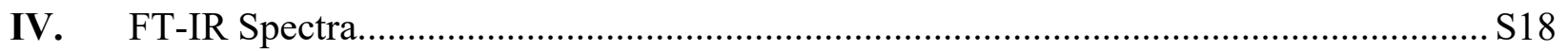

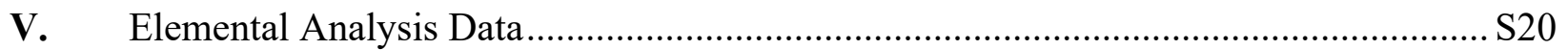

VI. Simulation of X-ray Diffraction Patterns for COF structures.................................... S25

VII. Powder X-ray Diffraction Data............................................................................. S29

VIII. Surface Area and Porosity Measurements ................................................................ S32

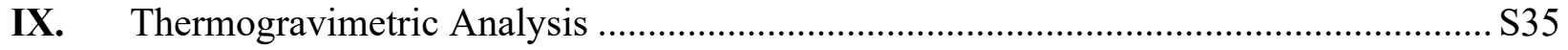

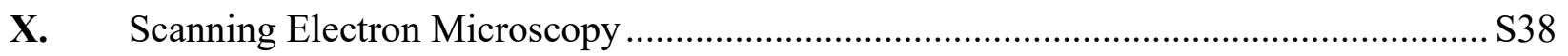

XI. Energy Dispersive X-ray Elemental Mapping ......................................................... S42

XII. Electrochemical Methods and Data .................................................................... S44

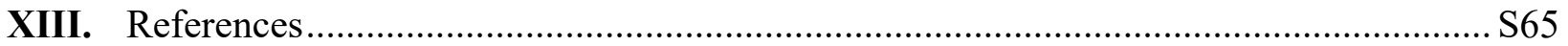




\section{Materials and Instrumentation}

\section{Materials}

All reactions were performed using flame-dried glassware under an atmosphere of nitrogen with dry solvents, unless otherwise stated. Dry tetrahydrofuran (THF), acetonitrile (MeCN), and toluene were obtained by passing previously degassed solvents through activated alumina columns. Tetrabutylammonium hexafluorophosphate $\left(\mathrm{TBAPF}_{6}\right)$ was purified by recrystallization from ethyl acetate three times and dried under reduced pressure at $60^{\circ} \mathrm{C}$ for 12 hours. $\mathrm{MeCN}$ for electrochemical measurements was dried over activated $4 \AA$ molecular sieve for $48 \mathrm{hr}$ before use. Super P carbon (Imerys Graphite\& Carbon) and poly(vinylidene fluoride) (PVDF) (Kynar Flex) were dried overnight in a vacuum oven at $60^{\circ} \mathrm{C}$ and stored in a desiccator. All other reagents were purchased from commercial sources and used without further purification, unless otherwise stated. Reactions were monitored by thin layer chromatography (TLC) carried out on EMD 250 $\mu \mathrm{m}$ silica gel 60-F254 plates. Visualization was performed by UV light irradiation and potassium permanganate stain and heat, and flash chromatography was performed on SiliaFlash ${ }^{\circledR}$ (particle size $40-63 \mu \mathrm{m})$.

\section{Instrumentation}

Nuclear Magnetic Resonance. Solution-phase ${ }^{1} \mathrm{H}$ and ${ }^{13} \mathrm{C}$ NMR spectra were acquired on Bruker AvanceIII-500 MHz equipped with a 5mm DHC with Z-Gradient CryoProbe and recorded at 25 ${ }^{\circ} \mathrm{C}$ with a $0 \mathrm{~Hz}$ spin rate. The spectra were calibrated using residual solvent as internal reference $\left(\mathrm{CDCl}_{3}\right.$ : $7.26 \mathrm{ppm}$ for ${ }^{1} \mathrm{H}$ NMR, 77.00 for ${ }^{13} \mathrm{C}$ NMR). The following abbreviations (or combination thereof) were used to explain multiplicities: $\mathrm{s}=$ singlet, $\mathrm{d}=$ doublet, $\mathrm{q}=$ quartet, $\mathrm{p}=$ pentet, $\mathrm{m}=$ multiplet, $b=$ broad. Solid-state ${ }^{13} \mathrm{C} C P / M A S$ NMR spectra were recorded on a Bruker AvanceIII$400 \mathrm{MHz}$ equipped with a $4 \mathrm{~mm} \mathrm{HX}$ probe at a spin rate of $15,000 \mathrm{~Hz}$ and calibrated using Adamantane as an external standard.

Fourier Transform Infrared Spectroscopy. Infrared spectra were recorded on a Nicolet iS10 FT-IR Spectrometer equipped with a ZnSe ATR attachment and are uncorrected. 
High Resolution Mass Spectrometry. High-resolution mass spectra were acquired on Agilent 6210A LC-TOF Mass Spectrometer, with Atmospheric Pressure Photoionization (APPI) as an ionization source. The instrument is equipped with an Agilent Series 1200 HPLC binary pump, and Autosampler, using Mass Hunter software. The samples were run using direct injection.

Elemental Analysis. Elemental analyses were performed by Robertson Microlit Laboratories.

Sonication. Sonication was performed with a Branson 3510 ultrasonic cleaner with a power output of $100 \mathrm{~W}$ and a frequency of $42 \mathrm{kHz}$.

Powdered X-ray Diffraction. Powdered X-ray diffraction (PXRD) patterns were obtained at room temperature on a STOE-STADI MP or a STOE-STADI P powder diffractometer equipped with an asymmetric curved Germanium monochromator $\left(\mathrm{CuK}_{\alpha 1}\right.$ radiation, $\left.\lambda=1.54056 \AA\right)$ and one-dimensional silicon strip detector (MYTHEN2 1K from DECTRIS). The line focused $\mathrm{Cu}$ Xray tube was operated at $40 \mathrm{kV}$ and $40 \mathrm{~mA}$. The as-obtained powder samples were sandwiched between two acetate foils (polymer sample with neither Bragg reflections nor broad peaks above $10^{\circ} 2 \theta$ ) mounted in flat plates with a disc opening diameter of $8 \mathrm{~mm}$, and measured in transmission geometry in a rotating holder. The patterns were recorded in the $2 \theta$ range of $0-32^{\circ}$ for an overall exposure time of $6 \mathrm{~min}$. The instrument was calibrated against a NIST Silicon standard (640d) prior to the measurement.

Gas Adsorption. Gas adsorption isotherms were conducted on a Micromeritics ASAP 2420 Accelerated Surface Area and Porosity Analyzer. Typically, 20-50 mg samples were transferred to dried and tared analysis tubes equipped with filler rods and capped with a Transeal. The samples were heated to $40{ }^{\circ} \mathrm{C}$ at a rate of $1{ }^{\circ} \mathrm{C} / \mathrm{min}$ and evacuated at $40{ }^{\circ} \mathrm{C}$ for $20 \mathrm{~min}$, then heated to $100^{\circ} \mathrm{C}$ at a rate of $1{ }^{\circ} \mathrm{C} / \mathrm{min}$ heat, and evacuated at $100{ }^{\circ} \mathrm{C}$ until the outgas rate was $\leq 0.3 \mu \mathrm{mHg} / \mathrm{min}$ (holding the samples at $100{ }^{\circ} \mathrm{C}$ for $5-8 \mathrm{~h}$ was sufficient), at which point the tube was weighed again to determine the mass of the activated sample. The tube was then transferred to the analysis port of the instrument. UHP-grade (99.999\% purity) $\mathrm{N}_{2}$ was used for all adsorption measurements. $\mathrm{N}_{2}$ isotherms were generated by incremental exposure to nitrogen up to $760 \mathrm{mmHg}(1 \mathrm{~atm})$ in a 
liquid nitrogen $(77 \mathrm{~K})$ bath. Oil-free vacuum pumps and oil-free pressure regulators were used for all measurements. Brunauer-Emmett-Teller (BET) surface areas were calculated from the linear region of the $\mathrm{N}_{2}$ isotherm at $77 \mathrm{~K}$ within the pressure range $P / P_{0}$ of $0.05-0.10$. All BET linear fits had a minimum $\mathrm{R}^{2}$ value of 0.999 .

Thermogravimetric Analysis. Thermogravimetric thermal analyses were performed in a Netzsch STA 449 F3 Jupiter Simultaneous Thermal Analysis (STA) instrument. Each sample (15 - 20 mg) was loaded and placed into a $0.35 \mathrm{~mL}$ Alumina crucible (equipped with an Alumina lid) with a weight of $742.539 \mathrm{mg}$. All samples were measured under UHP-grade Helium gas (flow of 50 $\mathrm{mL} / \mathrm{min}$ ). Buoyancy effect for Helium was corrected by measuring the empty Alumina crucible under the same measurement conditions used for the samples. Temperature was increased at a rate of $10^{\circ} \mathrm{C} / \mathrm{min}$ and gases were transferred to the $\mathrm{GC} / \mathrm{MS}$ instrumentation via a heated $\left(250^{\circ} \mathrm{C}\right)$ transfer line. An Agilent Technologies 7890A GC system equipped with a non-polar capillary column (Agilent J\&B HP-5 packed with (5\%-Phenyl)-methylpolysiloxane) coupled with a 5975 MSD spectrometer was used for the analyses of the gases released from the samples. A gas injection was triggered every minute from the beginning of the heating cycle and $0.25 \mathrm{~mL}$ of gas was sampled from the gases released by the compound and carrier gas (He). Detection limit is typically better than $100 \mathrm{fg}$ but this value can be larger, and it highly depends on the ionization efficiency of the different molecules in the compound. Mass spectra were scanned in the range of 10-500 u. Performance of the thermobalance in the STA was verified by using a certified sample of calcium oxalate monohydrate (European Pharmacopoeia Reference Standard) up to $1000^{\circ} \mathrm{C}$.

Scanning Electron Microscopy. Images were obtained using a Zeiss Gemini 500 scanning electron microscope. A working voltage of $1.0 \mathrm{kV}$ was used for imaging with a $20.0 \mu \mathrm{m}$ aperture. Samples were sputtered with a layer of carbon before imaging.

Energy Dispersive X-Ray Elemental Mapping. Elemental mapping was done using Aztec software with a Zeiss Gemini 500 SEM. An accelerating voltage of $10.0 \mathrm{kV}$ was used to capture the carbon, nitrogen, oxygen, and sulfur K edge. The PEDOT@COF samples were dispersed in 
NMP and drop-cast onto a clean silicon substrate. The NMP was evaporated off using a heat lamp. Samples for elemental mapping were not coated with carbon before imaging. 


\section{Synthetic Procedures}

\section{Synthesis of Monomers.}

2,6-diaminoanthraquinone (DAAQ) [Aldrich ${ }^{\circledR}$ ] and 3,4-ethylenedioxythiphene (EDOT) [Aldrich ${ }^{\circledR}$ ] are commercially available compounds and were used without further purification. Triformylphloroglucinol (TFP) is a previously reported compound, was prepared according to the reported procedure, and the NMR data is consistent with those reported. ${ }^{1}$ 2,7diaminophenazine $\cdot$ benzophenoneimine $(\mathrm{DAPH} \cdot \mathrm{Bnzph}, \mathrm{S} 5)$ was prepared through a three-step protocol (see below) using commercially available starting materials. 2,7-dibromophenazine (S4) was prepared from a two-step procedure adapted from a previous report. ${ }^{2}$

Scheme S1: Synthesis of DAPH·Bnzph (S5).
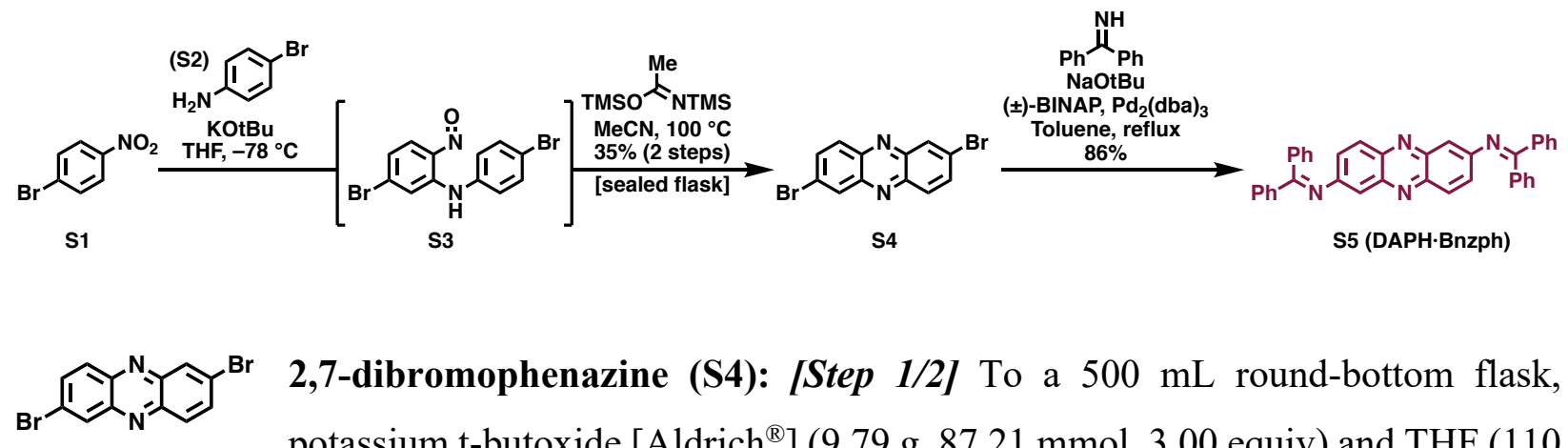

2,7-dibromophenazine (S4): [Step 1/2] To a $500 \mathrm{~mL}$ round-bottom flask, potassium t-butoxide [Aldrich ${ }^{\circledR}$ ] (9.79 g, $87.21 \mathrm{mmol}, 3.00$ equiv) and THF (110 $\mathrm{mL}$ ) were added, the flask was cooled to $-78^{\circ} \mathrm{C}$ (dry ice / acetone), and stirred for c.a. $10 \mathrm{~min} .4-$ bromoaniline [S2, Aldrich ${ }^{\circledR}$ ] (5.00 g, $29.07 \mathrm{mmol}, 1.00$ equiv) dissolved in THF $(30 \mathrm{~mL}) \mathrm{was}$ added dropwise via a syringe (c.a. $3 \mathrm{~min}$ ), followed by 1-bromo-4-nitrobenzene [S1, Aldrich ${ }^{\circledR}$ ] (5.87 g, $29.07 \mathrm{mmol}, 1.00$ equiv) dissolved in THF (30 mL) also added dropwise via a syringe (c.a. $3 \mathrm{~min}$ ). The reaction was stirred at $-78^{\circ} \mathrm{C}$ for $2 \mathrm{hrs}$, and the reaction mixture was poured into a stirring solution of saturated ammonium chloride $(350 \mathrm{~mL})$. The product was extracted with EtOAc $(3 \times 150 \mathrm{~mL})$, and the organics were combined, washed with water $(300 \mathrm{~mL})$ and brine $(300 \mathrm{~mL})$. The organics were collected, dried with anhydrous magnesium sulfate, filtered, and concentrated onto silica gel ( $\sim 10 \mathrm{~g})$. The residue was purified via flash column chromatography using a 0 to $20 \%$ EtOAc in hexanes gradient. All fractions containing $\mathbf{S 3}$ (red band; $\mathrm{R}_{f}=0.55$ in $10 \%$ EtOAc/hexanes) were collected to give the product (5.27 g, $\sim 85 \%$ purity) as a brown solid. 
[Step 2/2] To a $350 \mathrm{~mL}$ high-pressure flask, $\mathbf{S 3}(5.27 \mathrm{~g}, 14.72 \mathrm{mmol}, 1.00$ equiv - assume pure for equiv calculations), N,O-bis(trimethylsilyl)acetamide [Aldrich ${ }^{\circledR}$ ] $(18.0 \mathrm{~mL}, 73.60 \mathrm{mmol}, 5.00$ equiv), and $\mathrm{MeCN}(60 \mathrm{~mL})$ were added, the flask was sealed, and the reaction was stirred at $100{ }^{\circ} \mathrm{C}$ for $16 \mathrm{hrs}$. The flask was then gradually cooled to RT and the precipitate was collected via filtration and further washed with EtOH $(\sim 150 \mathrm{~mL})$ to give crude $\mathbf{S 4}$ (yellow solid, NMR purity of crude $>95 \%)$. The crude product was then purified via recrystallization $(\sim 4.0 \mathrm{~g}$ crude in a mixture of $\sim 1: 1 \mathrm{EtOH}: \mathrm{CHCl}_{3}, \sim 600 \mathrm{~mL}$ ) to afford the product as a light yellow fluffy solid ( $3.40 \mathrm{~g}, 35 \%$ yield over two steps). Note: although solubility of $\mathbf{S} 4$ is poor in $\mathrm{CDCl}_{3}$, a $13 \mathrm{C}$ NMR spectrum could be collected in a CryoProbe-equipped NMR spectrometer.

${ }^{1} \mathbf{H}$ NMR (500 MHz, $\left.\mathbf{C D C l}_{3}\right) \delta 8.43(\mathrm{~d}, \mathrm{~J}=2.1 \mathrm{~Hz}, 2 \mathrm{H}), 8.10(\mathrm{~d}, \mathrm{~J}=9.2 \mathrm{~Hz}, 2 \mathrm{H}), 7.91(\mathrm{dd}, \mathrm{J}=$ 9.2, $2.1 \mathrm{~Hz}, 2 \mathrm{H})$.

${ }^{13}$ C NMR (126 MHz, CDCl $) \delta$ 143.64, 142.33, 134.92, 131.71, 130.87, 125.36.

Characterization data is consistent with those previously reported. ${ }^{2}$

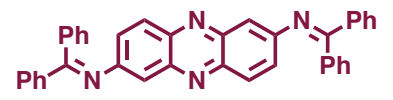

2,7-diaminophenazine $\cdot$ benzophenoneimine (DAPH·Bnzph, S5): To a $500 \mathrm{~mL}$ round-bottom flask, $( \pm)$-BINAP [Aldrich $\left.{ }^{\circledR}\right](1.40 \mathrm{~g}, 2.25 \mathrm{mmol}$, 0.30 equiv), tris(dibenzylideneacetone)dipalladium( 0$)$ [Aldrich ${ }^{\circledR}$ ] $(0.69 \mathrm{~g}, 0.75 \mathrm{mmol}, 0.10$ equiv), and toluene $(135 \mathrm{~mL})$ were added, and the reaction mixture was purged with nitrogen over $30 \mathrm{~min}$ at RT. The reaction mixture was then stirred under reflux for $1 \mathrm{hr}$, cooled to RT, and under a nitrogen atmosphere, solid sodium t-butoxide [Aldrich ${ }^{\circledR}$ ] was added, followed by solid $\mathbf{S 4}$ (2.54 g, $7.50 \mathrm{mmol}, 1.00$ equiv), and benzophenone imine [Aldrich ${ }^{\circledR}$ ] (3.26 g, $18.00 \mathrm{mmol}, 2.40$ equiv) dissolved in toluene $(5 \mathrm{~mL})$. More toluene $(15 \mathrm{~mL})$ was added to wash the walls of the flask, and the reaction mixture was again heated and stirred under reflux for $16 \mathrm{hrs}$. The reaction mixture was cooled to RT and toluene was removed in vacuo. To this residue, EtOH $(\sim 300 \mathrm{~mL})$ was added, the slurry was stirred at $\sim 80{ }^{\circ} \mathrm{C}$ for $30 \mathrm{~min}$, and the solid was collected via hot filtration to give crude DAPH·Bnzph (S5) (yellow solid, NMR purity of crude $>90 \%$ ). The crude product was then purified via recrystallization $\left(\sim 4.5 \mathrm{~g}\right.$ crude in a mixture of $\left.\sim 1: 1 \mathrm{EtOH}: \mathrm{CHCl}_{3}, \sim 850 \mathrm{~mL}\right)$. The crude solid took some time to fully dissolve in the hot solution, but once dissolved, the solution was allowed to slowly cool to RT and then stored in a freezer over $48 \mathrm{hrs}$ to afford the product as a bright yellow solid ( $3.49 \mathrm{~g}, 86 \%$ yield). 
${ }^{1}$ H NMR (500 MHz, CDCl $) \delta 7.91(\mathrm{~d}, \mathrm{~J}=9.1 \mathrm{~Hz}, 2 \mathrm{H}), 7.82(\mathrm{~m}, 4 \mathrm{H}), 7.62-7.41(\mathrm{~m}, 6 \mathrm{H}), 7.35$ $(\mathrm{d}, \mathrm{J}=2.2 \mathrm{~Hz}, 2 \mathrm{H}), 7.29(\mathrm{dd}, \mathrm{J}=9.1,2.3 \mathrm{~Hz}, 2 \mathrm{H}), 7.22(\mathrm{~m}, 10 \mathrm{H})$.

${ }^{13}$ C NMR (126 MHz, CDCl $) \delta 169.36,152.47,143.12,141.31,138.96,135.62,131.25,129.60$, 129.30, 129.03, 128.31, 128.21, 127.97, 116.30 .

HRMS (APPI) ${ }^{+} m / z$ calculated for $\mathrm{C}_{38} \mathrm{H}_{27} \mathrm{~N}_{4}[\mathrm{M}+\mathrm{H}]^{+}:$539.2230; found: 539.2236. 


\section{Synthesis of COFs.}

Covalent organic frameworks were prepared using reaction conditions adapted from our previous reports. ${ }^{3}$ Each COF is thoroughly washed with hot solvents to remove unreacted monomers and soluble oligomers, and finally dried under high vacuum at $120^{\circ} \mathrm{C}$ to remove any remaining solvent.

Scheme S2: Synthesis of DAAQ-TFP COF.

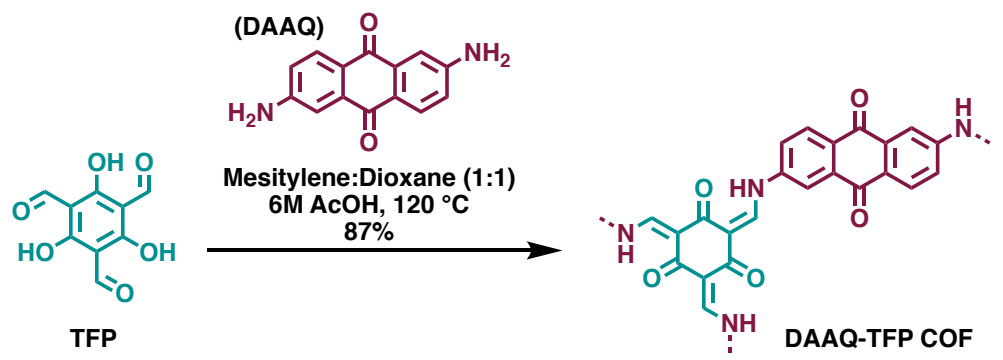

DAAQ-TFP COF: To a $150 \mathrm{~mL}$ high-pressure flask equipped with a vacuum valve, TFP $(0.63 \mathrm{~g}$, $3.0 \mathrm{mmol}, 1.0$ equiv) and 2,6-diaminoanthraquinone (DAAQ) (1.07 g, $4.5 \mathrm{mmol}, 1.5$ equiv) were added, followed by mesitylene:dioxane $(1: 1,30 \mathrm{~mL})$ along the walls of the flask (to push down any remaining solids remaining atop of the flask). The flask was sealed and sonicated at room temperature for $10 \mathrm{~min} .6 \mathrm{M}$ acetic acid $(5 \mathrm{~mL})$ was subsequently added directly to the reaction mixture, which was then degassed through three freeze-pump-thaw cycles (vacuum $<50$ mTorr). The high-pressure flask was ultimately charged with $\mathrm{N}_{2}$ and sealed under a positive $\mathrm{N}_{2}$ pressure ( 1-2 psi). The flask was then placed (no stirring) in a $120{ }^{\circ} \mathrm{C}$ pre-heated oil bath for three days. The flask was removed from the oil bath, allowed to cool, and filtered through a Buchner funnel equipped with a filter paper. Acetone was used to ensure all of the material is filtered from the flask to the Buchner funnel. The solid was collected and stirred in an Erlenmeyer flask in hot DMF (200 $\mathrm{mL}$ at $90^{\circ} \mathrm{C}$ for $30 \mathrm{~min}$ ), and then filtered while hot. This procedure was repeated again in DMF (200 $\mathrm{mL}$ at $90{ }^{\circ} \mathrm{C}$ for $30 \mathrm{~min}$ ), in absolute ethanol $\left(200 \mathrm{~mL}\right.$ at $80{ }^{\circ} \mathrm{C}$ for $30 \mathrm{~min}$ ), and lastly in acetone $\left(200 \mathrm{~mL}\right.$ at $\left.60^{\circ} \mathrm{C}\right)$. The material was then filtered and collected. The collected material was then transferred to a tared vial and dried at $120^{\circ} \mathrm{C}$ under vacuum ( $\sim 20$ mTorr) over 24 hrs to give DAAQ-TFP COF as a light red solid (1.35 g, 87\% yield).

Solid-state CP/MAS ${ }^{13}$ C NMR (101 MHz) $\delta$ 182.19, 177.47, 142.09, 134.25, 128.70, 115.56, $107.95,102.26$.

Elemental Analysis calculated for $\mathrm{C}_{30} \mathrm{H}_{15} \mathrm{~N}_{3} \mathrm{O}_{6}$ : C 70.18\%, H 2.94\%, N 8.18\%; found: C 65.92\%, H $3.48 \%$, N 7.12\%. 
Scheme S3: Synthesis of DAPH-TFP COF.

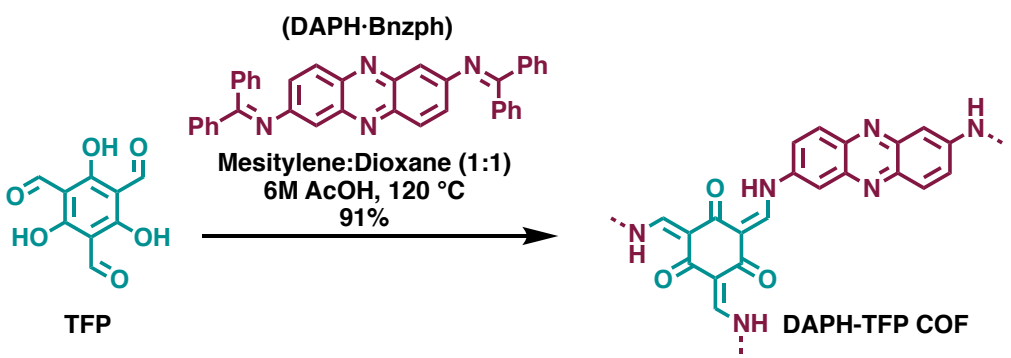

DAPH-TFP COF: To a $250 \mathrm{~mL}$ high-pressure flask equipped with a vacuum valve, TFP $(0.84 \mathrm{~g}$, $4.0 \mathrm{mmol}, 1.0$ equiv) and 2,7-diaminophenazine benzophenoneimine (DAPH·Bnzph) (3.23 g, 6.0 mmol, 1.5 equiv) were added, followed by mesitylene:dioxane $(1: 1,40 \mathrm{~mL})$ along the walls of the flask (to push down any remaining solids remaining atop of the flask). The flask was sealed and sonicated at room temperature for $10 \mathrm{~min} .6 \mathrm{M}$ acetic acid $(6.7 \mathrm{~mL})$ was subsequently added directly to the reaction mixture, which was then degassed through three freeze-pump-thaw cycles (vacuum $<50$ mTorr). The high-pressure flask was ultimately charged with $\mathrm{N}_{2}$ and sealed under a positive $\mathrm{N}_{2}$ pressure ( 1-2 psi). The flask was covered with aluminum foil to prevent any lightinduced benzophenone-enabled undesired reaction, and then placed (no stirring) in a $120{ }^{\circ} \mathrm{C}$ preheated oil bath for three days. The flask was removed from the oil bath, allowed to cool, and filtered through a Buchner funnel equipped with a filter paper. Acetone was used to ensure all of the material is filtered from the flask to the Buchner funnel. The solid was collected, stirred in an Erlenmeyer flask in hot DMF ( $300 \mathrm{~mL}$ at $90^{\circ} \mathrm{C}$ for $30 \mathrm{~min}$ ), and filtered while hot. This procedure was repeated again in DMF $\left(300 \mathrm{~mL}\right.$ at $90{ }^{\circ} \mathrm{C}$ for $\left.30 \mathrm{~min}\right)$, in absolute ethanol $\left(300 \mathrm{~mL}\right.$ at $80^{\circ} \mathrm{C}$ for $30 \mathrm{~min})$, and lastly in acetone $\left(300 \mathrm{~mL}\right.$ at $\left.60^{\circ} \mathrm{C}\right)$. The material was then filtered and collected. The collected material was then transferred to a tared jar and dried at $120{ }^{\circ} \mathrm{C}$ under vacuum $(\sim 20$ mTorr) over 24 hrs to give DAPH-TFP COF as a reddish purple solid (1.72 g, 91\% yield).

Solid-state CP/MAS ${ }^{13}$ C NMR (101 MHz) $\delta$ 183.98, 140.97, 129.48, 123.68, 115.60, 115.56, 107.77, 102.47 .

Elemental Analysis calculated for $\mathrm{C}_{27} \mathrm{H}_{15} \mathrm{~N}_{6} \mathrm{O}_{3}: \mathrm{C} 68.79 \%, \mathrm{H} 3.21 \%, \mathrm{~N} 17.83 \%$; found: $\mathrm{C} 65.61 \%$, H 3.66\%, N 16.44\%. 


\section{Synthesis of PEDOT@COF composites.}

Each COF was activated under high vacuum ( 20 mTorr) at $120^{\circ} \mathrm{C}$ for $48 \mathrm{hrs}$ immediately prior to use. Each composite material (PEDOT@COF) is thoroughly washed with hot solvents to remove remaining reactants and soluble oligomers, and finally dried under high vacuum at $120{ }^{\circ} \mathrm{C}$ to remove any remaining solvent in the pores of the COFs. As is evidenced by elemental analysis, the intercalated PEDOT in the pores of each COF is natively doped with chloride.

Scheme S4: Synthesis of PEDOT@COF composites.
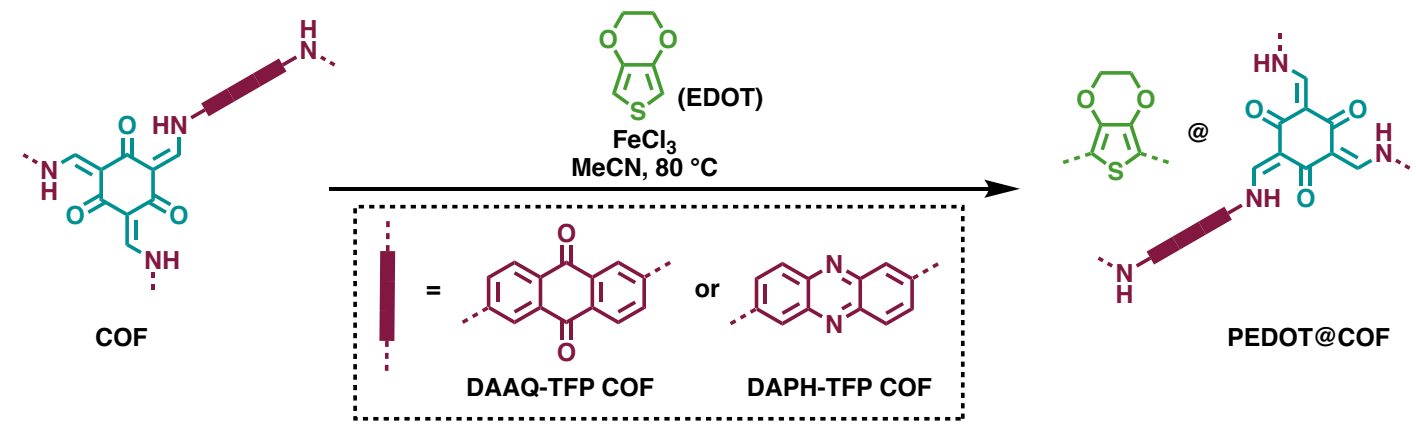

General synthetic procedure of PEDOT@COF. To a $100 \mathrm{~mL}$ round-bottom flask equipped with a reflux condenser, freshly activated COF (DAAQ-TFP COF: $200 \mathrm{mg}, 0.39 \mathrm{mmol}, 0.56$ equiv; DAPH-TFP COF: $200 \mathrm{mg}, 0.42 \mathrm{mmol}, 0.60$ equiv) and acetonitrile (15 mL) were added and the slurry was stirred at RT under nitrogen. Iron(III) chloride (250 mg, $1.54 \mathrm{mmol}, 2.20$ equiv) in acetonitrile $(10 \mathrm{~mL})$ was syringed in and the reaction was warmed to $80{ }^{\circ} \mathrm{C}$ and continued to stir under nitrogen. After $10 \mathrm{~min}, 3,4-$ ethylenedioxythiophene [EDOT] (100 mg, $0.70 \mathrm{mmol}, 1.00$ equiv; 2:1 mass loading of COF : EDOT) in acetonitrile ( $2 \mathrm{~mL})$ was syringed in dropwise over c.a. $1 \mathrm{~min}$ and the reaction was stirred at $80^{\circ} \mathrm{C}$ over $12 \mathrm{hrs}$. The solid was collected in a Buchner funnel equipped with a filter paper, and acetonitrile was used to ensure all of the material is collected from the flask to the Buchner funnel, and washed with hot acetonitrile $(\sim 50 \mathrm{~mL})$. The solid was then stirred in an Erlenmeyer flask in hot $\mathrm{MeOH}\left(100 \mathrm{~mL}\right.$ at $80^{\circ} \mathrm{C}$ for $\left.30 \mathrm{~min}\right)$ and filtered while hot. This procedure was repeated two more times in $\mathrm{MeOH}$ [until the filtrate is colorless] (100 $\mathrm{mL}$ at $80{ }^{\circ} \mathrm{C}$ for $\left.30 \mathrm{~min}\right)$ and one time in acetone $\left(100 \mathrm{~mL}\right.$ at $60{ }^{\circ} \mathrm{C}$ for $\left.30 \mathrm{~min}\right)$. The collected solid was then transferred to a tared vial and dried at $90{ }^{\circ} \mathrm{C}$ under vacuum ( $\left.\sim 20 \mathrm{mTorr}\right)$ over 24 hrs to givePEDOT@COF composite materials. 


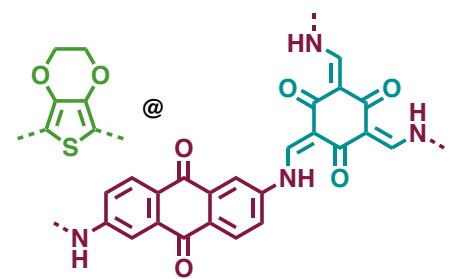

PEDOT@DAAQ-TFP COF: dark brown solid (210 mg).

Solid-state CP/MAS ${ }^{13}$ C NMR (101 MHz) $\delta 183.46,179.67,143.37$, $133.92,128.61,116.59,108.11,102.17,66.07$.

Elemental Analysis calculated for $\mathrm{C}_{24} \mathrm{H}_{13} \mathrm{~N}_{1.8} \mathrm{O}_{5.6} \mathrm{~S}$ : C $64.31 \%, \mathrm{H}$ 2.92\%, N 5.08\%, S 7.15\%; found: C 62.61\%, H 3.30\%, N 5.88\%, S 3.36, Cl 0.67\%.

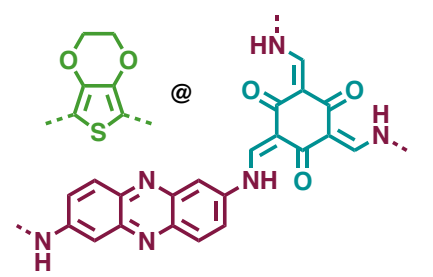

PEDOT@DAPH-TFP COF: black solid (215 mg).

Solid-state CP/MAS ${ }^{13}$ C NMR (101 MHz) $\delta$ 183.92, 140.79, 129.41, $125.59,116.71,107.71,102.91,66.17$.

Elemental Analysis calculated for $\mathrm{C}_{22.2} \mathrm{H}_{13} \mathrm{~N}_{3.6} \mathrm{O}_{3.8} \mathrm{~S}$ : C $63.03 \%, \mathrm{H}$ $3.10 \%$, N 11.92\%, S 7.58\%; found: C 62.76\%, H 3.31\%, N 12.63\%, S 2.42, Cl 1.42\%. 


\section{Synthesis of PEDOT.}

PEDOT (poly(3,4-ethylenedioxythiophene)) was prepared for comparison purposes using the same reaction conditions that were used to polymerize EDOT in the pores of the COFs. As is evidenced by elemental analysis, the bare PEDOT is natively doped with chloride.

Scheme S5: Synthesis of bare PEDOT.

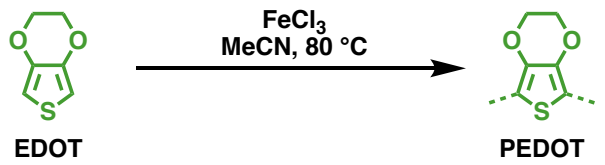

PEDOT: To a $100 \mathrm{~mL}$ round-bottom flask equipped with a reflux condenser, iron(III) chloride (250 mg, $1.54 \mathrm{mmol}, 2.20$ equiv) was added and the flask was purged with nitrogen at RT. Acetonitrile $(25 \mathrm{~mL})$ was syringed in and the red solution was warmed to $80{ }^{\circ} \mathrm{C}$ and continued to stir under nitrogen. After $2 \mathrm{~min}, 3,4$-ethylenedioxythiophene [EDOT] (100 mg, $0.70 \mathrm{mmol}, 1.00$ equiv; 2:1 mass loading of COF : EDOT) in acetonitrile $(2 \mathrm{~mL})$ was syringed in dropwise over c.a. $1 \mathrm{~min}$ and the reaction was stirred at $80^{\circ} \mathrm{C}$ over $12 \mathrm{hrs}$. The solid was collected in a Buchner funnel equipped with a filter paper, and acetonitrile was used to ensure all of the material is collected from the flask to the Buchner funnel, and washed with hot acetonitrile ( $\sim 50 \mathrm{~mL})$. The solid was then stirred in an Erlenmeyer flask in hot $\mathrm{MeOH}\left(50 \mathrm{~mL}\right.$ at $80^{\circ} \mathrm{C}$ for $\left.30 \mathrm{~min}\right)$ and filtered while hot. This procedure was repeated two more times in $\mathrm{MeOH}$ [until the filtrate was colorless] (50 $\mathrm{mL}$ at $80^{\circ} \mathrm{C}$ for $\left.30 \mathrm{~min}\right)$ and one time in acetone $\left(50 \mathrm{~mL}\right.$ at $60^{\circ} \mathrm{C}$ for $\left.30 \mathrm{~min}\right)$. The collected solid was then transferred to a tared jar and dried at $90{ }^{\circ} \mathrm{C}$ under vacuum ( $\sim 20$ mTorr) over 24 hrs to give PEDOT as a black solid (105 $\mathrm{mg})$.

Solid-state CP/MAS ${ }^{13}$ C NMR (101 MHz) $\delta$ 138.85, 118.62, 65.92.

Elemental Analysis calculated for $\mathrm{C}_{6} \mathrm{H}_{4} \mathrm{O}_{2} \mathrm{~S}$ : C $51.42 \%$, H 2.88\%, S 22.87\%; found: C 43.75\%, H $2.44 \%$, S $16.91, \mathrm{Cl} 6.44 \%$. 


\section{NMR Spectra}

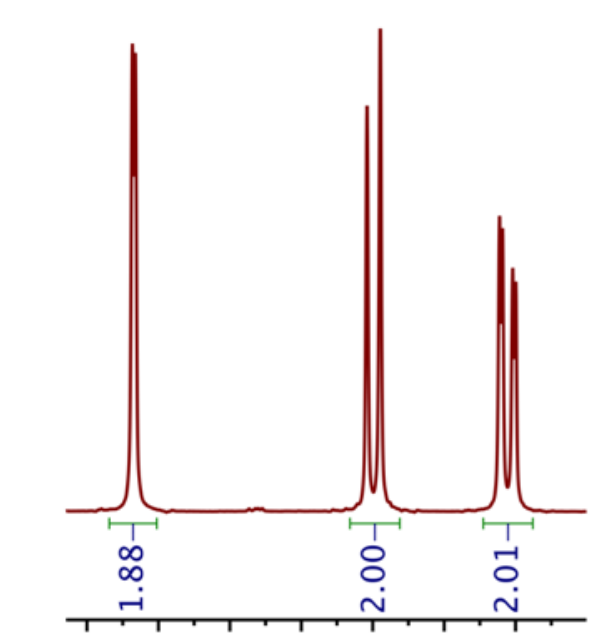

ষ

$\infty \infty \infty N N N$<smiles>Brc1ccc2nc3ccc(Br)cc3nc2c1</smiles>

$\begin{array}{lllllll}8.5 & 8.4 & 8.3 & 8.2 & 8.1 & 8.0 & 7.9\end{array}$ Chemical Shift (ppm)
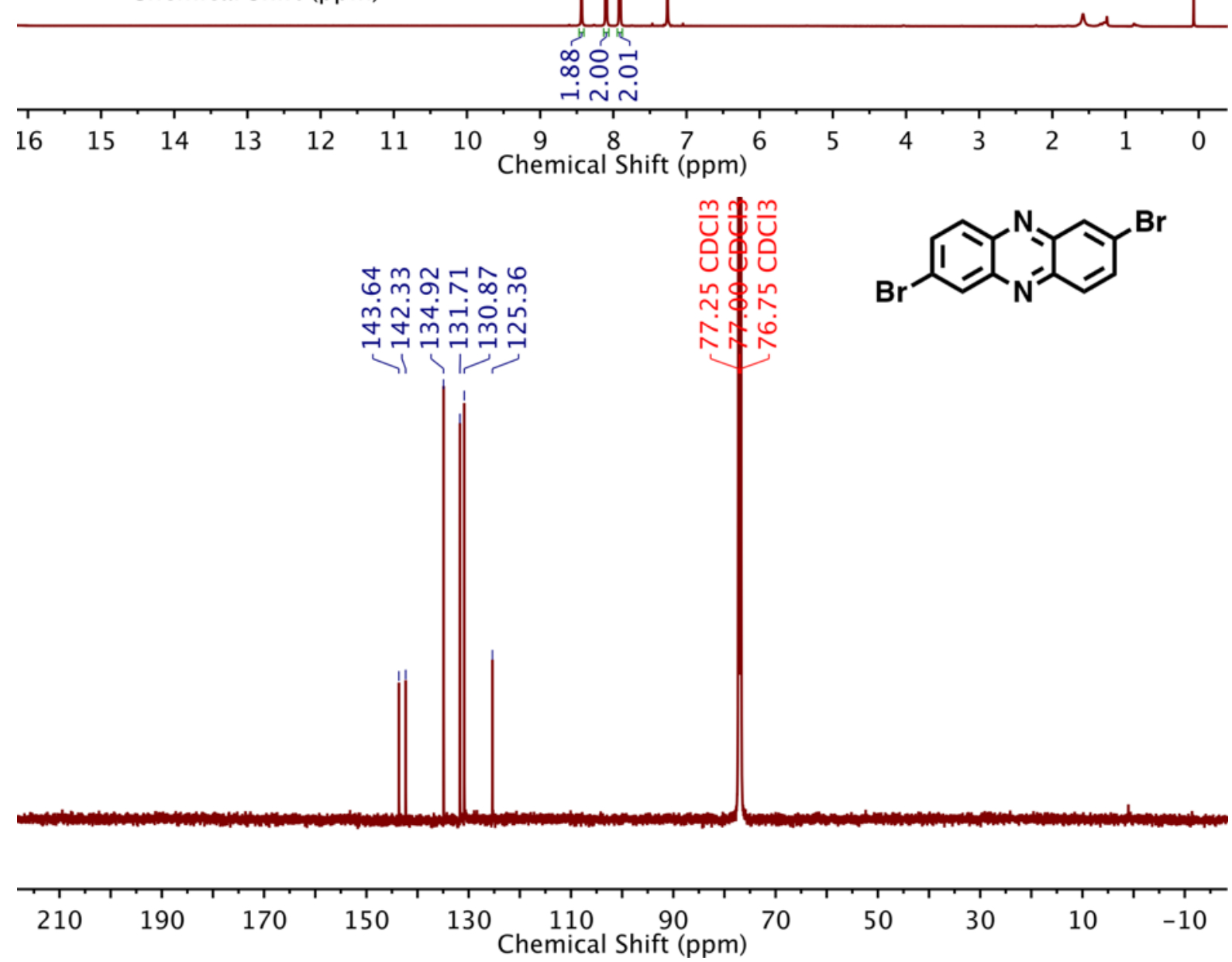

Figure S1: (Top) 1H and (Bottom) 13C NMR of 2,7-dibromophenazine (S4). 

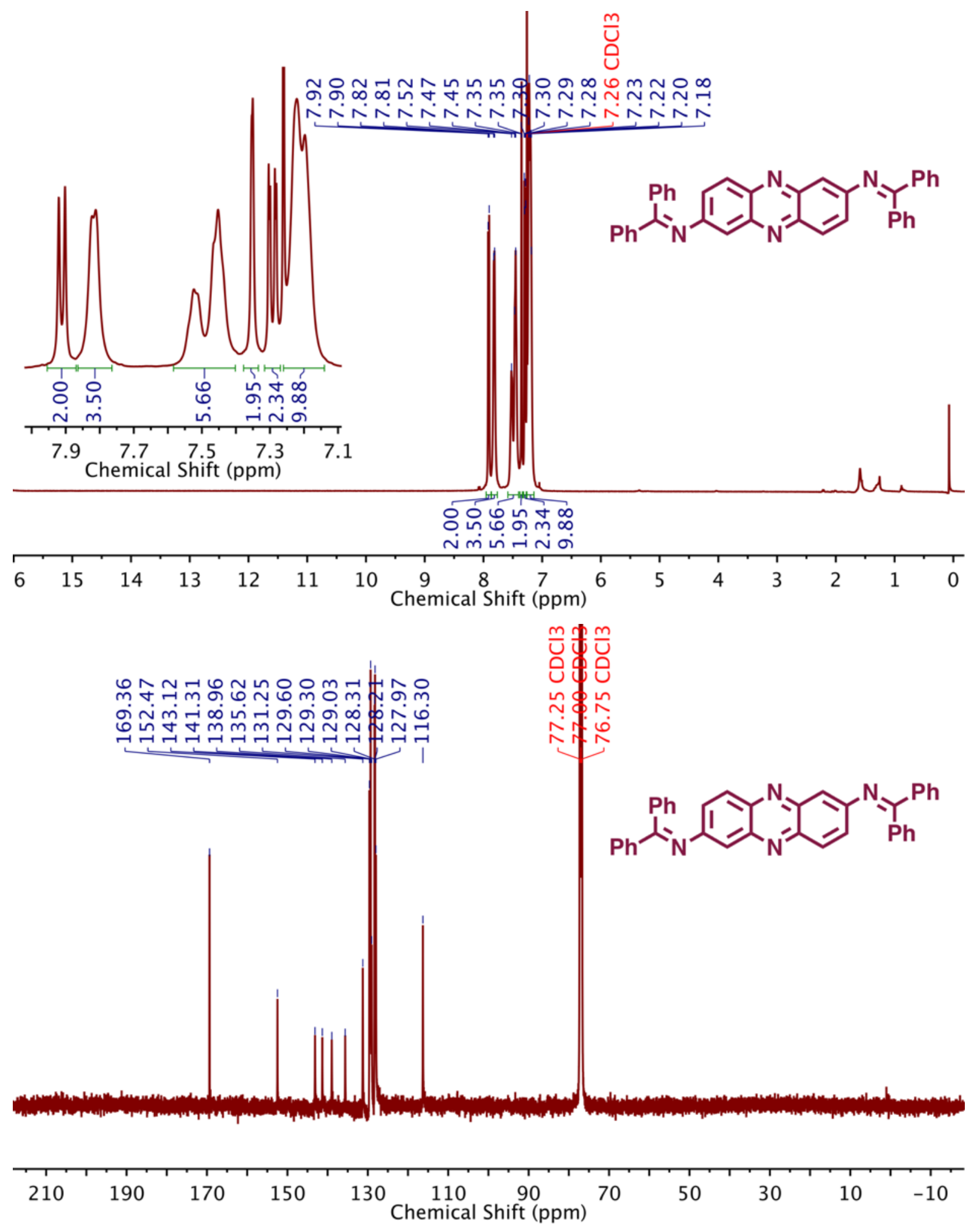

Figure S2. (Top) $1 \mathrm{H}$ and (Bottom) 13C NMR of 2,7-diaminophenazine - benzophenoneimine (DAPH·Bnzph, S5). 

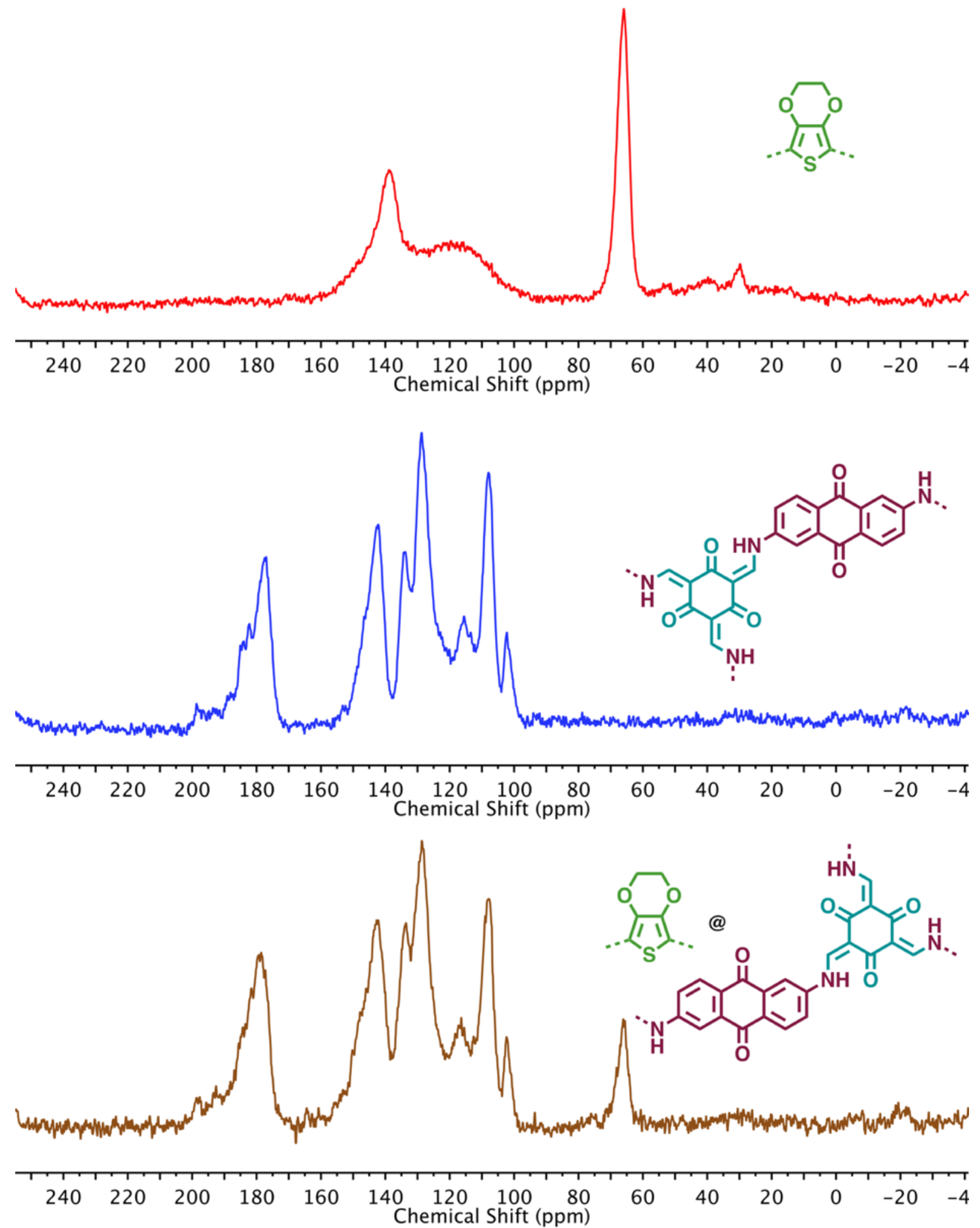

Figure S3. Solid-state CP/MAS 13C NMR of (Top) PEDOT, (Middle) DAAQ-TFP COF, and (Bottom) PEDOT@DAAQ-TFP COF. 

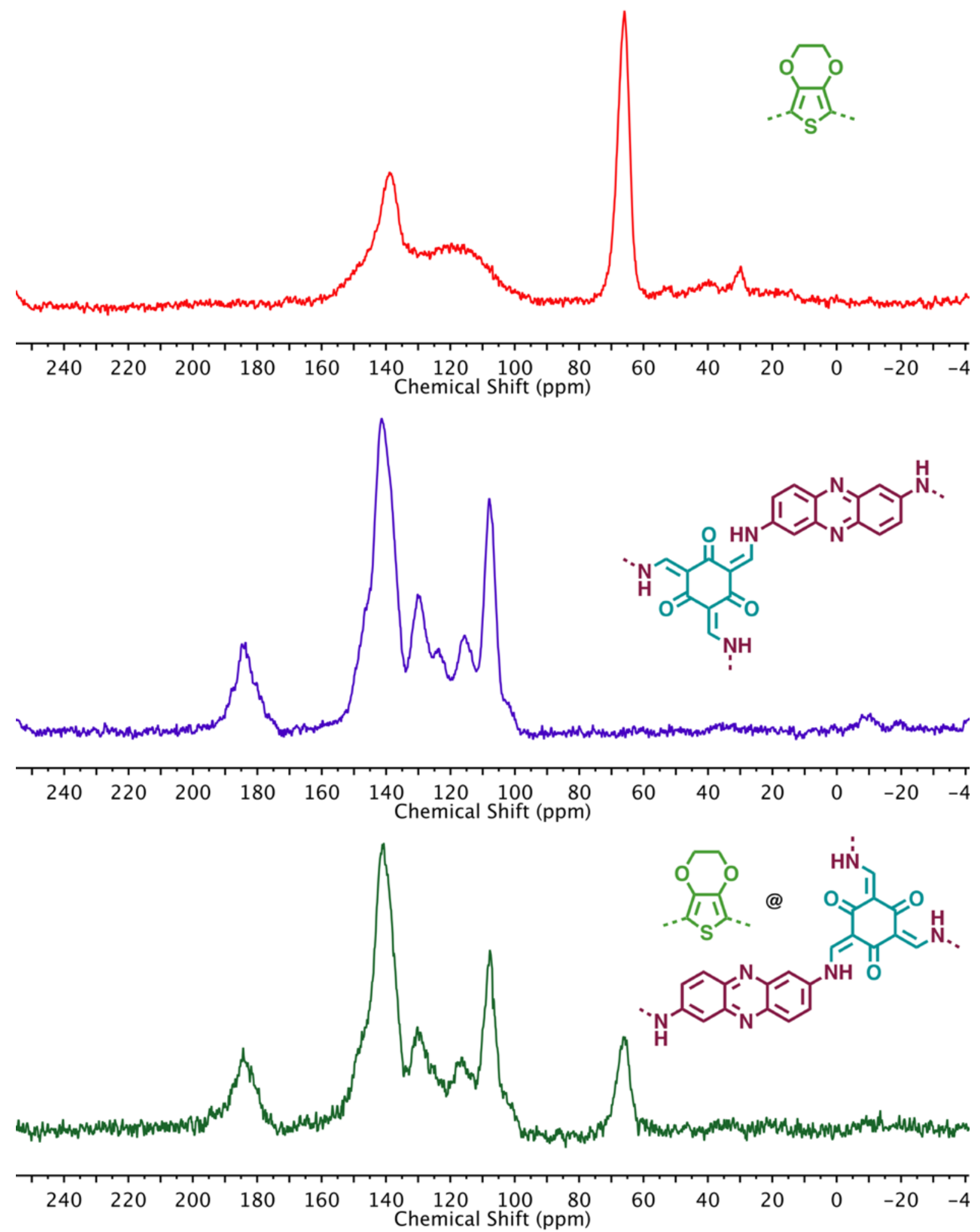

Figure S4. Solid-state CP/MAS 13C NMR of (Top) PEDOT, (Middle) DAPH-TFP COF, and (Bottom)PEDOT@DAPH-TFPCOF. 


\section{FT-IR Spectra}

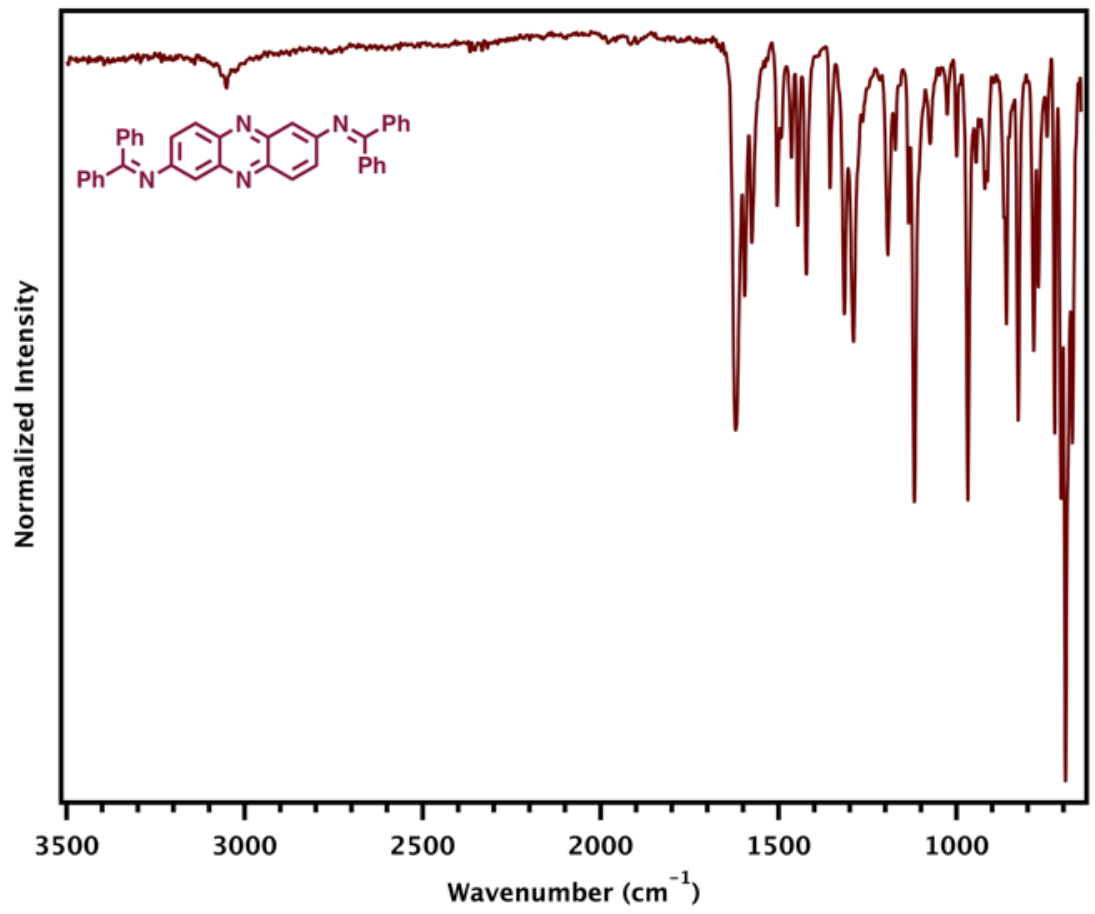

Figure S5. FT-IR spectrum of DAPH·Bnzph. 


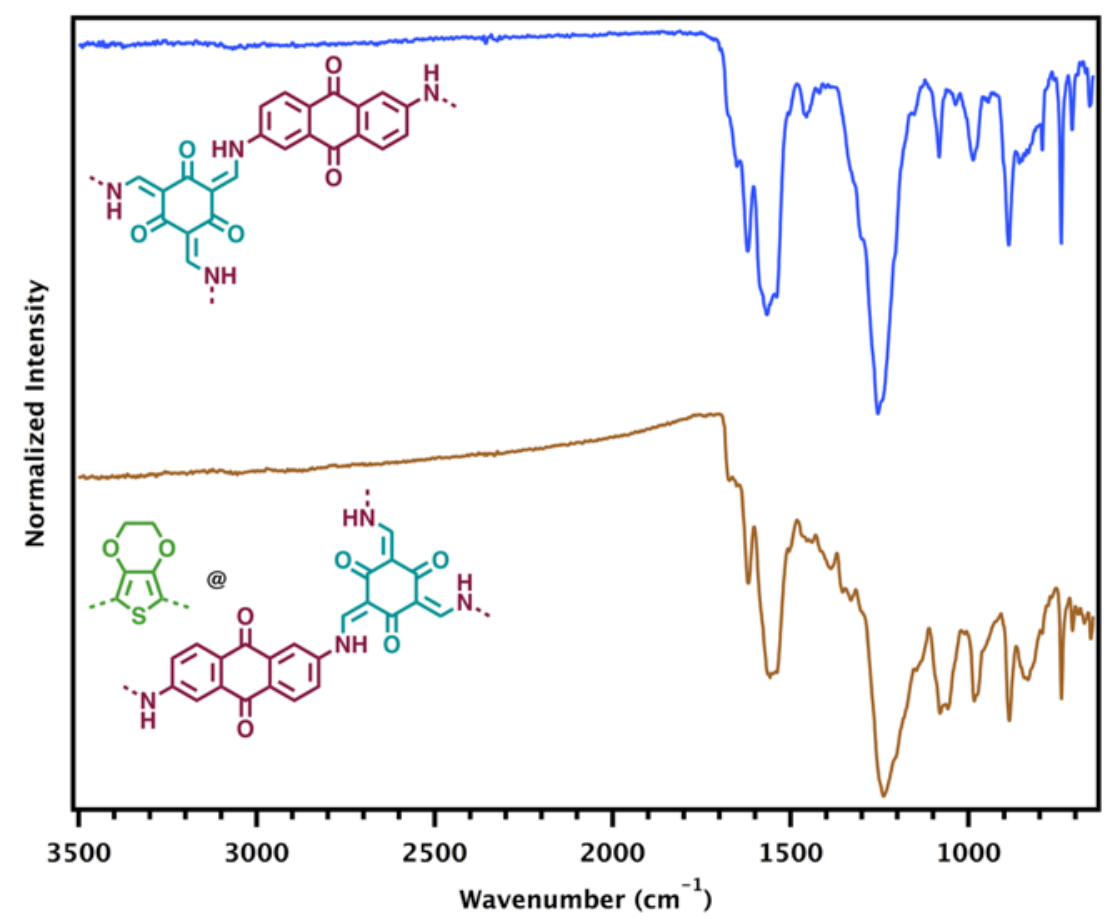

Figure S6. FT-IR spectra of (Top) DAAQ-TFP COF, and (Bottom) PEDOT@DAAQ-TFP COF.

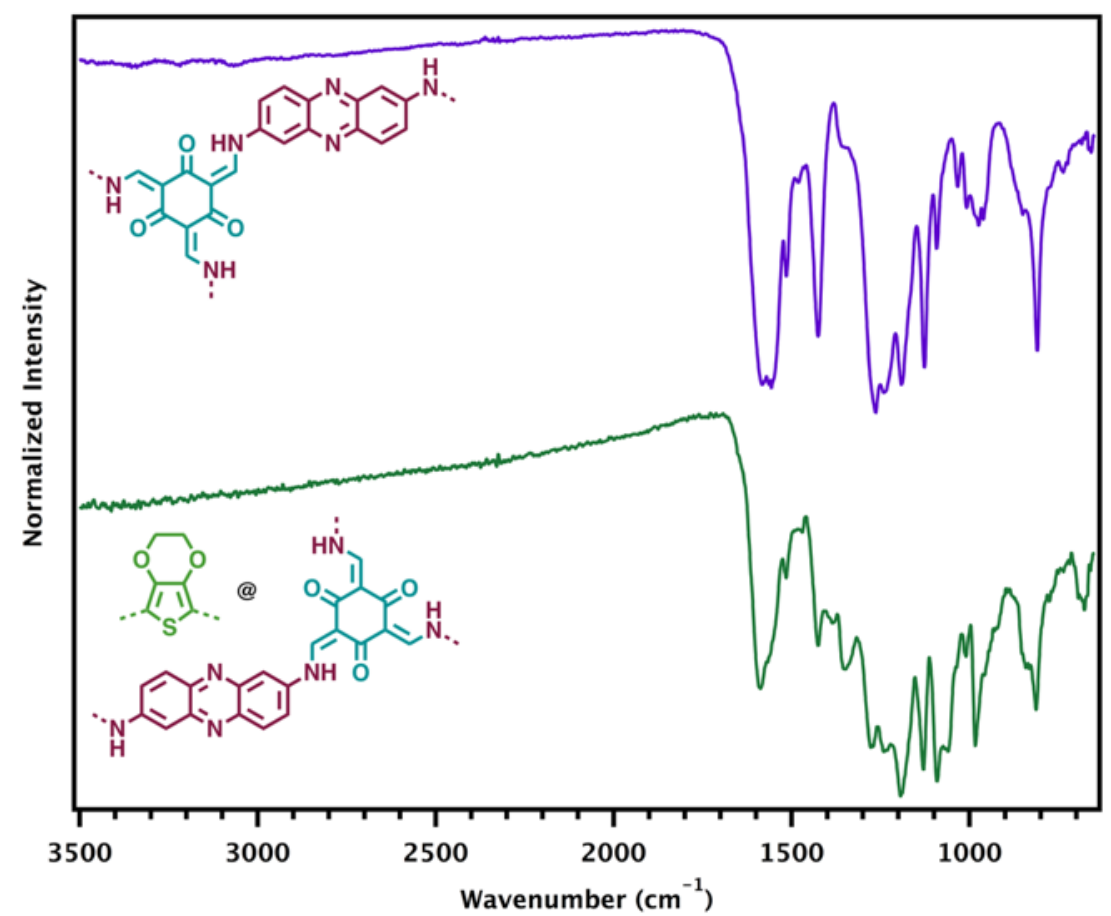

Figure S7. FT-IR spectra of (Top) DAPH-TFP COF, and (Bottom) PEDOT@DAPH-TFP COF. 


\section{Elemental Analysis Data}

The atomic formulas of COFs were calculated based on the experimental equivalent ratio of monomers, while the atomic formulas for PEDOT@COFs were calculated based on the experimental equivalent ratio of COFs to EDOT used (shown above each elemental analysis table). Theoretical percent composition and experimental atomic formulas were calculated based on the following atomic weights: C 12.011; H 1.008; N 14.007; O 15.999; S 32.060, Cl 35.453. Experimental percent composition data was used to calculate the empirical atomic formula where the Nitrogen atom was defined as the lowest denominator for the COF samples, while the Sulfur atom was defined as the lowest denominator for the PEDOT@COF and bare PEDOT samples. For PEDOT@COF samples, the experimental N/S and S/Cl ratios were used to calculate: (1) the obtained COF/PEDOT mass and mole ratios, (2) the molecular weight of each composite material, and (3) the number of moles of anthraquinones (for PEDOT@DAAQ-TFP COF) and phenazines (PEDOT@DAPH-TFP COF) per gram of composite material (see below for tabulated and sample calculations). Theoretical mass ratio of $\mathrm{COF} / \mathrm{PEDOT}$ was defined as the experimental mass ratio of COF to EDOT, which was 2:1 for each PEDOT@COF composite material. As is evidenced by elemental analysis, the intercalated PEDOT in the pores of each COF, as well as the bare PEDOT sample, are natively doped with ionic chlorine species from $\mathrm{FeCl}_{3}$ oxidative polymerization. Elemental analysis shows that insignificant amount (less than $0.10 \%$ ) of iron is present in PEDOT@COF samples.

Table S1. Elemental Analysis of DAAQ-TFP COF

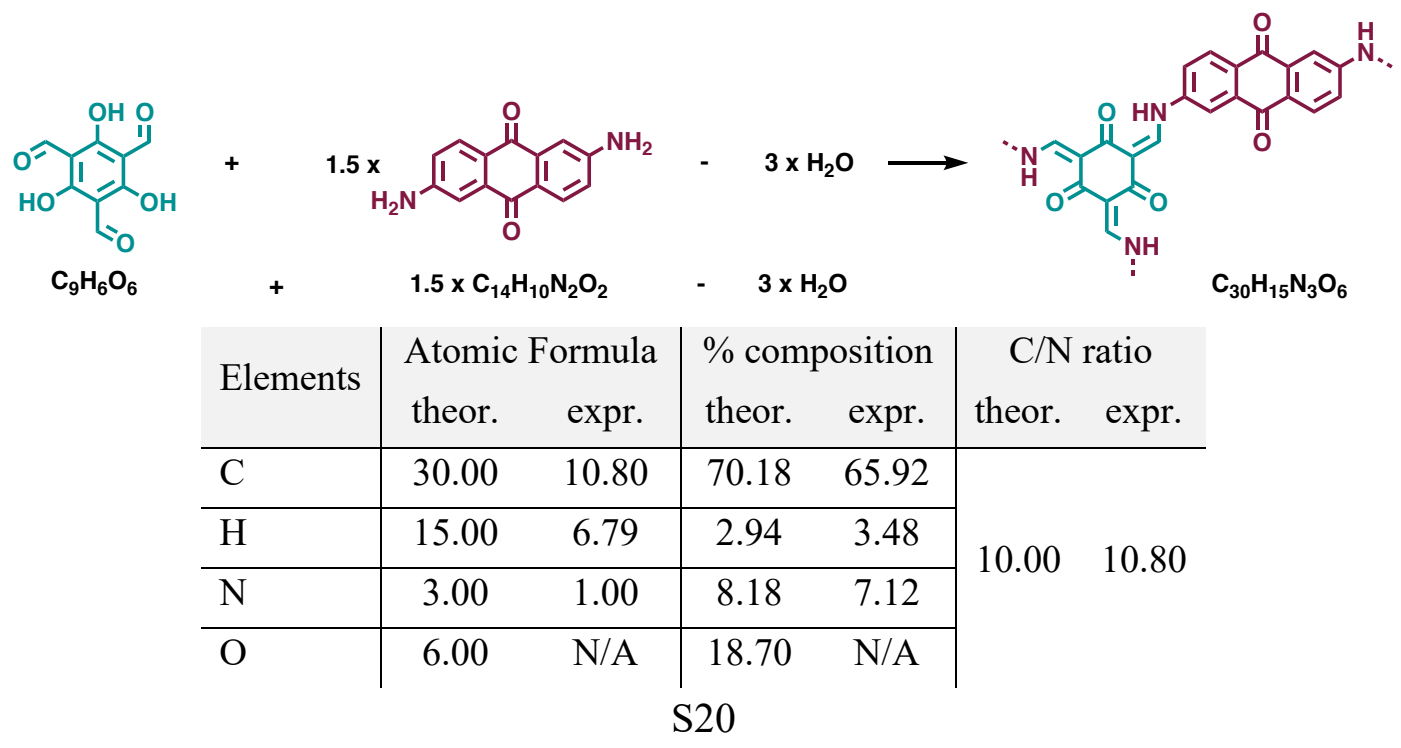


Table S2. Elemental Analysis of DAPH-TFP COF

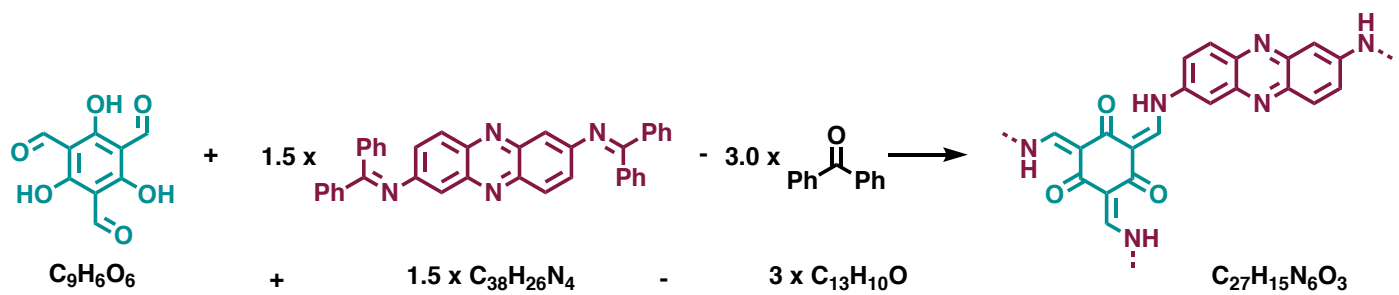

\begin{tabular}{|c|c|c|c|c|c|c|}
\hline \multirow{2}{*}{ Elements } & \multicolumn{2}{|c|}{ Atomic Formula } & \multicolumn{2}{|c|}{$\%$ composition } & \multicolumn{2}{|c|}{$\mathrm{C} / \mathrm{N}$ ratio } \\
\hline & theor. & expr. & theor. & expr. & theor. & expr. \\
\hline $\mathrm{C}$ & 27.00 & 4.65 & 65.79 & 65.61 & \multirow{4}{*}{4.50} & \multirow{4}{*}{4.65} \\
\hline $\mathrm{H}$ & 15.00 & 3.09 & 3.21 & 3.66 & & \\
\hline $\mathrm{N}$ & 6.00 & 1.00 & 17.83 & 16.44 & & \\
\hline $\mathrm{O}$ & 3.00 & $\mathrm{~N} / \mathrm{A}$ & 10.18 & N/A & & \\
\hline
\end{tabular}

Table S3. Elemental Analysis of PEDOT@DAAQ-TFP COF

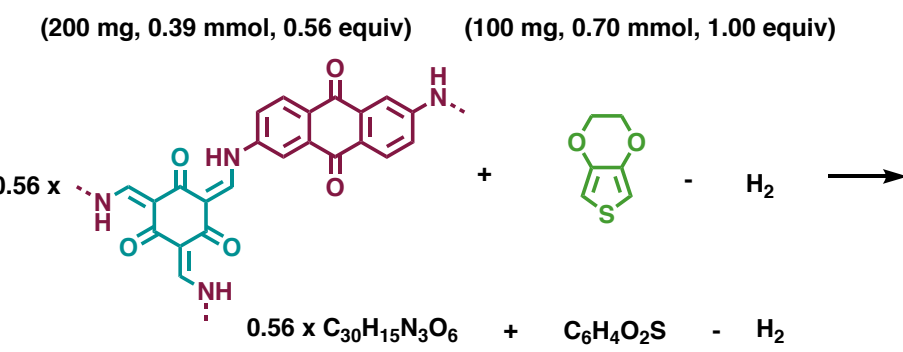

\begin{tabular}{|c|c|c|c|c|c|c|c|c|c|c|}
\hline \multirow{2}{*}{ Elements } & \multicolumn{2}{|c|}{ Atomic } & \multicolumn{2}{|c|}{$\%$ composition } & \multicolumn{2}{|c|}{$\mathrm{C} / \mathrm{N}$ ratio } & \multicolumn{2}{|c|}{$\mathrm{N} / \mathrm{S}$ ratio } & \multicolumn{2}{|c|}{$\mathrm{S} / \mathrm{Cl}$ ratio } \\
\hline & theor. & expr. & theor & expr. & theor. & expr. & theor. & expr. & theor. & expr. \\
\hline $\mathrm{C}$ & 22.80 & 49.74 & 64.03 & 62.61 & \multirow{6}{*}{13.57} & \multirow{6}{*}{12.42} & \multirow{6}{*}{1.68} & \multirow{6}{*}{4.01} & \multirow{6}{*}{ N/A } & \multirow{6}{*}{5.55} \\
\hline $\mathrm{H}$ & 12.40 & 31.24 & 2.92 & 3.30 & & & & & & \\
\hline $\mathrm{N}$ & 1.68 & 4.01 & 5.50 & 5.88 & & & & & & \\
\hline $\mathrm{O}$ & 5.36 & N/A & 20.05 & N/A & & & & & & \\
\hline $\mathrm{S}$ & 1.00 & 1.00 & 7.50 & 3.36 & & & & & & \\
\hline $\mathrm{Cl}$ & 0.00 & 0.18 & 0.00 & 0.67 & & & & & & \\
\hline $\mathrm{Fe}$ & $\mathrm{N} / \mathrm{A}$ & N/A & $\mathrm{N} / \mathrm{A}$ & 0.09 & & & & & & \\
\hline
\end{tabular}

Table S4. Calculated composition of PEDOT@DAAQ-TFP COF

\begin{tabular}{l|c|c|c|c|c} 
& $\begin{array}{c}\text { mass ratio: } \\
\text { COF / } \\
\text { PEDOT }\end{array}$ & $\begin{array}{c}\text { mol ratio: } \\
\text { COF / } \\
\text { PEDOT }\end{array}$ & $\begin{array}{c}\text { mol ratio: } \\
\text { COF / PEDOT / } \\
\text { Cl }\end{array}$ & $\begin{array}{c}\text { mmol } \\
\text { anthraquinones / } \\
\text { gram composite }\end{array}$ & $\begin{array}{c}\text { MW } \\
\text { composite } \\
(\mathrm{g} / \mathrm{mol})\end{array}$ \\
\hline theor. & $2.00: 1$ & $0.56: 1.00$ & $0.56: 1.00: 0.00$ & $2.01 \mathrm{mmol} / \mathrm{g}$ & 448.23 \\
\hline expr. & $4.91: 1$ & $1.34: 1.00$ & $1.34: 1.00: 0.18$ & $2.41 \mathrm{mmol} / \mathrm{g}$ & 834.58
\end{tabular}


Table S5. Elemental Analysis of PEDOT@DAPH-TFP COF

(200 mg, $0.42 \mathrm{mmol}, 0.60$ equiv) $\quad$ (100 mg, $0.70 \mathrm{mmol}, 1.00$ equiv)

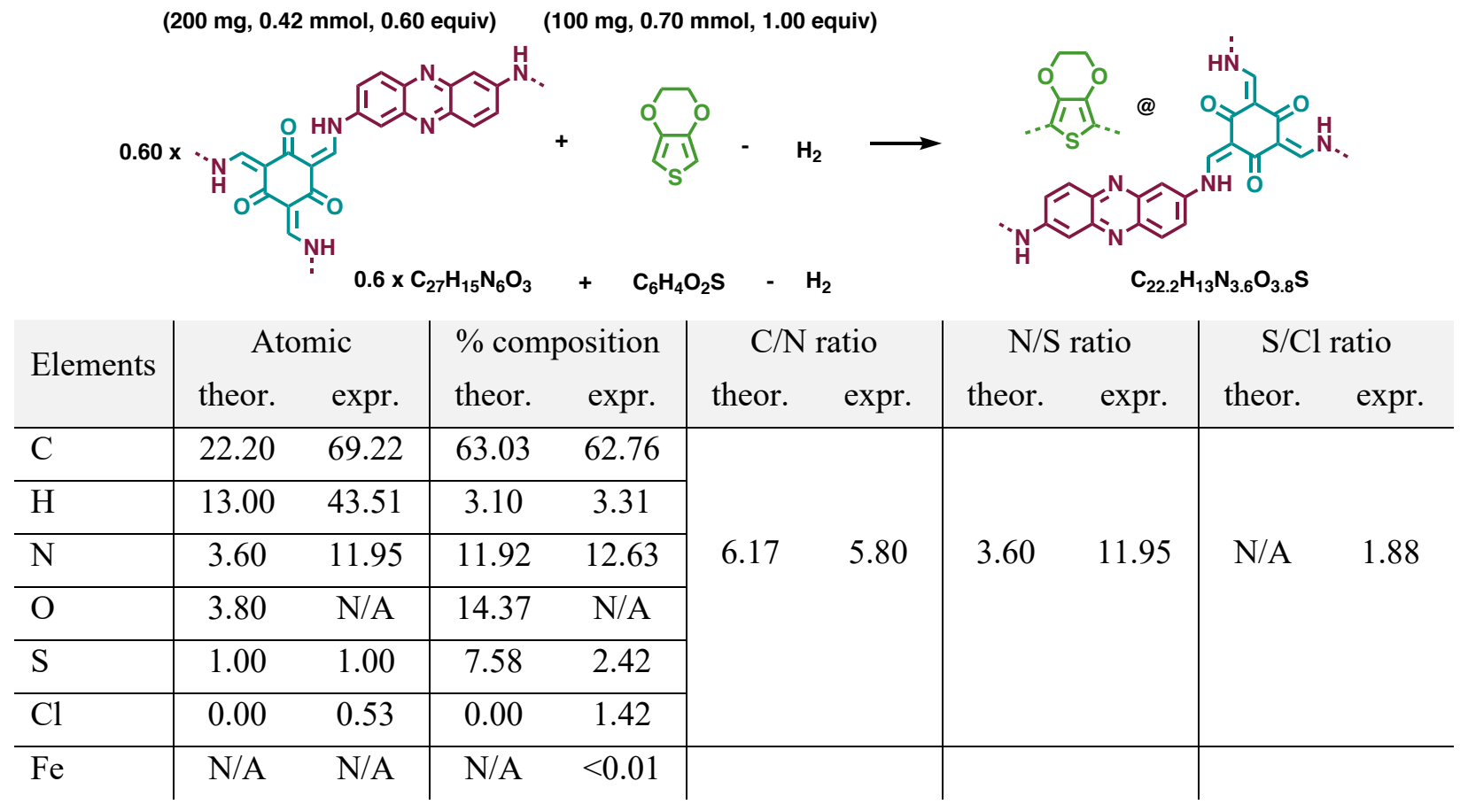

Table S6. Calculated composition of PEDOT@DAPH-TFP COF

\begin{tabular}{l|c|c|c|c|c} 
& $\begin{array}{c}\text { mass ratio: } \\
\text { COF / } \\
\text { PEDOT }\end{array}$ & $\begin{array}{c}\text { mol ratio: } \\
\text { COF } / \\
\text { PEDOT }\end{array}$ & $\begin{array}{c}\text { mol ratio: } \\
\text { COF / PEDOT / } \\
\text { Cl }\end{array}$ & $\begin{array}{c}\text { mmol phenazines / } \\
\text { gram composite }\end{array}$ & $\begin{array}{c}\text { MW } \\
\text { composite } \\
(\mathrm{g} / \mathrm{mol})\end{array}$ \\
\hline theor. & $2.00: 1$ & $0.60: 1.00$ & $0.60: 1.00: 0.00$ & $2.13 \mathrm{mmol} / \mathrm{g}$ & 423.03 \\
\hline expr. & $6.70: 1$ & $1.99: 1.00$ & $1.99: 1.00: 0.53$ & $2.72 \mathrm{mmol} / \mathrm{g}$ & 1097.14
\end{tabular}

Table S7. Elemental Analysis of bare PEDOT

\begin{tabular}{|c|c|c|c|c|c|c|}
\hline & $\mathrm{C}_{6} \mathrm{H}_{6} \mathrm{C}$ & - & & & $\mathrm{O}_{2} \mathrm{~S}$ & \\
\hline \multirow{2}{*}{ Elements } & \multicolumn{2}{|c|}{ Atomic Formula } & \multicolumn{2}{|c|}{$\%$ composition } & \multicolumn{2}{|c|}{$\mathrm{S} / \mathrm{Cl}$ ratio } \\
\hline & theor. & expr. & theor & expr. & theor. & expr. \\
\hline $\mathrm{C}$ & 6.00 & 6.91 & 51.42 & 43.75 & \multirow{5}{*}{ N/A } & \multirow{5}{*}{2.90} \\
\hline $\mathrm{H}$ & 4.00 & 4.59 & 2.88 & 2.33 & & \\
\hline $\mathrm{O}$ & 2.00 & N/A & 22.83 & N/A & & \\
\hline $\mathrm{S}$ & 1.00 & 1.00 & 22.87 & 16.91 & & \\
\hline $\mathrm{Cl}$ & 0.00 & 0.34 & 0.00 & 6.44 & & \\
\hline
\end{tabular}




\section{Sample Calculation for composition of PEDOT@COF samples.}

The following values were used for the below calculations:

\begin{tabular}{|c|c|c|c|c|c|}
\hline & Atomic Formula & MW (g/mol) & $\begin{array}{c}\text { mol N / } \\
\text { mol } \\
\text { compound }\end{array}$ & $\begin{array}{c}\text { mol S / } \\
\text { mol } \\
\text { compound }\end{array}$ & redox moiety / mole \\
\hline DAAQ-TFP COF & $\mathrm{C}_{30} \mathrm{H}_{15} \mathrm{~N}_{3} \mathrm{O}_{6}$ & 513.465 & 3 & N/A & 1.5 anthraquinones \\
\hline DAPH-TFP COF & $\mathrm{C}_{27} \mathrm{H}_{15} \mathrm{~N}_{6} \mathrm{O}_{3}$ & 471.456 & 6 & $\mathrm{~N} / \mathrm{A}$ & 1.5 phenazines \\
\hline PEDOT & $\mathrm{C}_{6} \mathrm{H}_{4} \mathrm{O}_{2} \mathrm{~S}$ & 140.159 & $\mathrm{~N} / \mathrm{A}$ & 1 & 1.0 thiophenes \\
\hline
\end{tabular}

Mole ratios of COF / PEDOT are calculated from the N/S ratios obtained from elemental analysis. Below is a sample calculation for PEDOT@DAAQ-TFP COF composite sample:

$$
\frac{\mathrm{COF}}{\text { PEDOT }} \text { mol ratio }=\frac{4.01 \mathrm{~mol} \mathrm{~N}}{1 \mathrm{~mol} \mathrm{~S}} * \frac{1 \mathrm{~mol} \mathrm{COF}}{3 \mathrm{~mol} \mathrm{~N}} * \frac{1 \mathrm{~mol} \mathrm{~S}}{1 \mathrm{~mol} \mathrm{PEDOT}}=1.34
$$

Mass ratios of $\mathrm{COF} / \mathrm{PEDOT}$ are calculated from the above COF/PEDOT mol ratios. Below is a sample calculation for PEDOT@DAAQ-TFP COF composite sample:

$$
\frac{\mathrm{COF}}{\mathrm{PEDOT}} \text { mass ratio }=\frac{1.34 \mathrm{~mol} \mathrm{COF}}{\mathrm{mol} \mathrm{PEDOT}} * \frac{513.465 \mathrm{~g} \mathrm{COF}}{\mathrm{mol} \mathrm{COF}} * \frac{\mathrm{mol} \mathrm{PEDOT}}{140.159 \mathrm{~g} \text { PEDOT }}=4.91
$$

$\mathrm{Mol}$ ratio of $\mathrm{Cl}$ / $\mathrm{PEDOT}$ are calculated from the $\mathrm{S} / \mathrm{Cl}$ ratios from the elemental analysis. Below is a sample calculation for PEDOT@DAAQ-TFP COF composite sample:

$$
\frac{\mathrm{Cl}}{\text { PEDOT }} \text { mol ratio }=\frac{1 \mathrm{~mol} \mathrm{Cl}}{5.55 \mathrm{~mol} \mathrm{~S}} * \frac{1 \mathrm{~mol} \mathrm{~S}}{1 \mathrm{~mol} \mathrm{PEDOT}}=0.18
$$

Molecular weight of PEDOT@COF composites are calculated based on the COF / PEDOT / Cl mol ratios. Below is a sample calculation for PEDOT@DAAQ-TFP COF composite sample:

$$
\begin{gathered}
\mathrm{MW}=\frac{1.34 \mathrm{~mol} \mathrm{COF}}{\mathrm{mol} \mathrm{PEDOT@COF}} * \frac{513.465 \mathrm{~g}}{\mathrm{~mol} \mathrm{COF}}+\frac{1.00 \mathrm{~mol} \mathrm{PEDOT}}{\mathrm{mol} \mathrm{PEDOT} @ C O F} * \frac{140.159 \mathrm{~g}}{\mathrm{~mol} \mathrm{PEDOT}} \\
+\frac{0.18 \mathrm{~mol} \mathrm{Cl}}{\mathrm{mol} \mathrm{PEDOT} @ \mathrm{COF}} * \frac{35.453 \mathrm{~g}}{\mathrm{~mol} \mathrm{Cl}}=834.58 \mathrm{~g} / \mathrm{mol}
\end{gathered}
$$


Number of mmol redox-active moieties per gram of composite material are calculated based on the moles of redox-active moieties per mole of COF in the composite material. Below is a sample calculation for PEDOT@DAAQ-TFP COF composite sample:

mmol anthraquinones per gram composite material $=$

$$
\begin{aligned}
& =\frac{1.34 \mathrm{~mol} \mathrm{COF}}{\mathrm{mol} \mathrm{PEDOT} @ \mathrm{COF}} * \frac{1.5 \mathrm{~mol} \text { anthraquinones }}{\mathrm{mol} \mathrm{COF}} * \frac{\mathrm{mol} \text { PEDOT@COF }}{834.58 \mathrm{~g} \text { PEDOT@COF }} \\
& * \frac{1000 \mathrm{mmol} \text { anthraquinones }}{\mathrm{mol} \text { anthraquinones }}=2.41 \mathrm{mmol} / \mathrm{g}
\end{aligned}
$$




\section{Simulation of X-ray Diffraction Patterns for COF structures}

The Accelrys ${ }^{4}$ Materials Studio (version 5.0) program suite was used to simulate the powder diffraction of DAAQ-TFP and DAPH-TFP COFs. The initial structures were built from a hexagonal unit cell with a P6 space group. The $a$ cell parameter was approximated from the corresponding experimental PXRD data of obtained COFs. The starting interlayer stacking ( $c$ cell parameter) was chosen to be $3.4 \AA$. The structure was optimized using the Geometry Optimization routine including energy minimization with cell parameters optimization, using the parameters from the Universal Force Field. ${ }^{5}$ The simulated PXRDs were calculated with the Reflex Plus module. The experimental data was subjected to a Pawley refinement where the peak positions and line shape parameters were refined using the Pseudo-Voigt peak shape position ${ }^{6,7}$ until further refinements resulted in no additional changes.

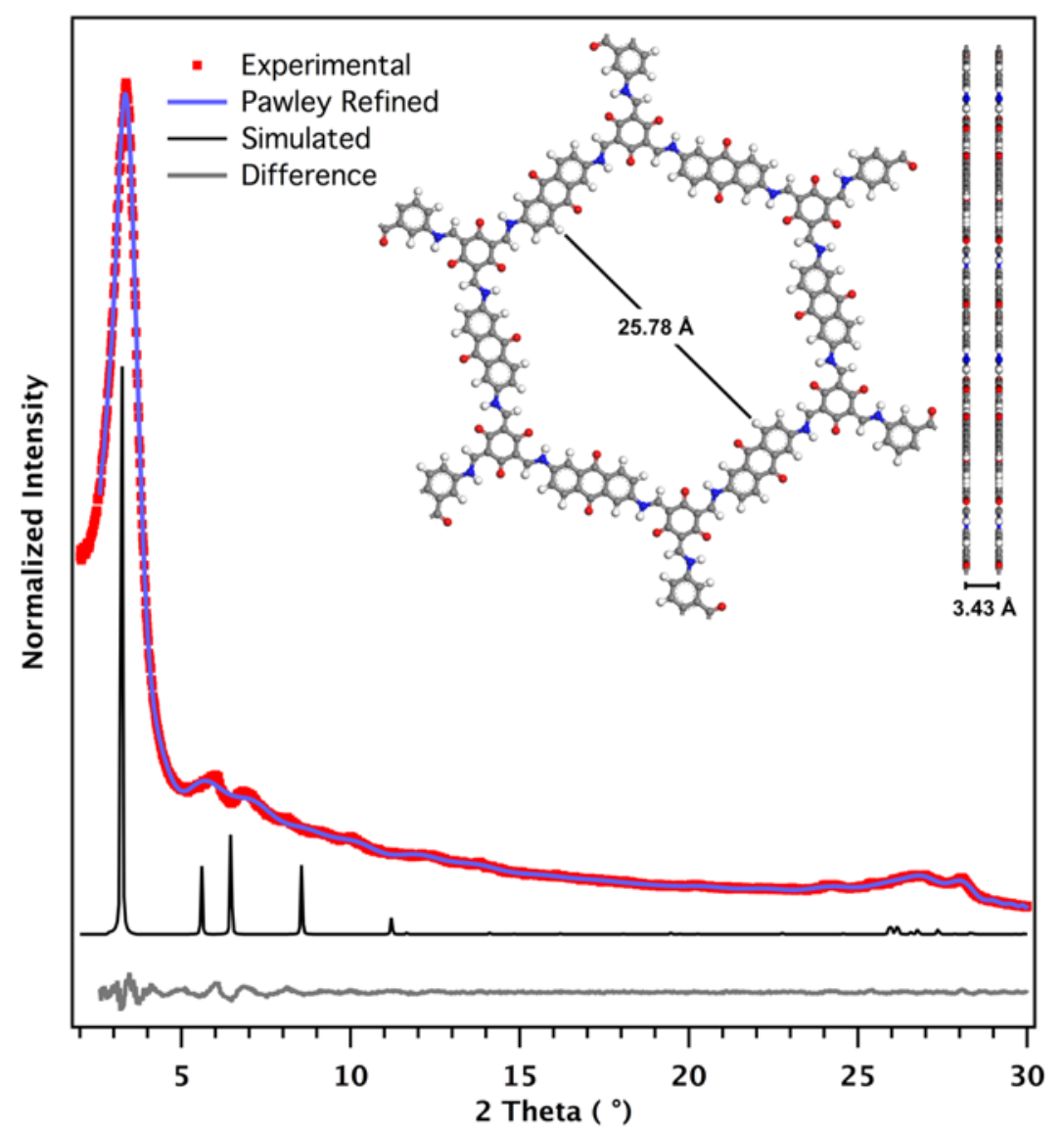

Figure S8. DAAQ-TFP COF PXRD patterns for experimental (red), Pawley-refined (blue), simulated eclipsed (black), and a difference plot (gray; experimental minus refined pattern). 


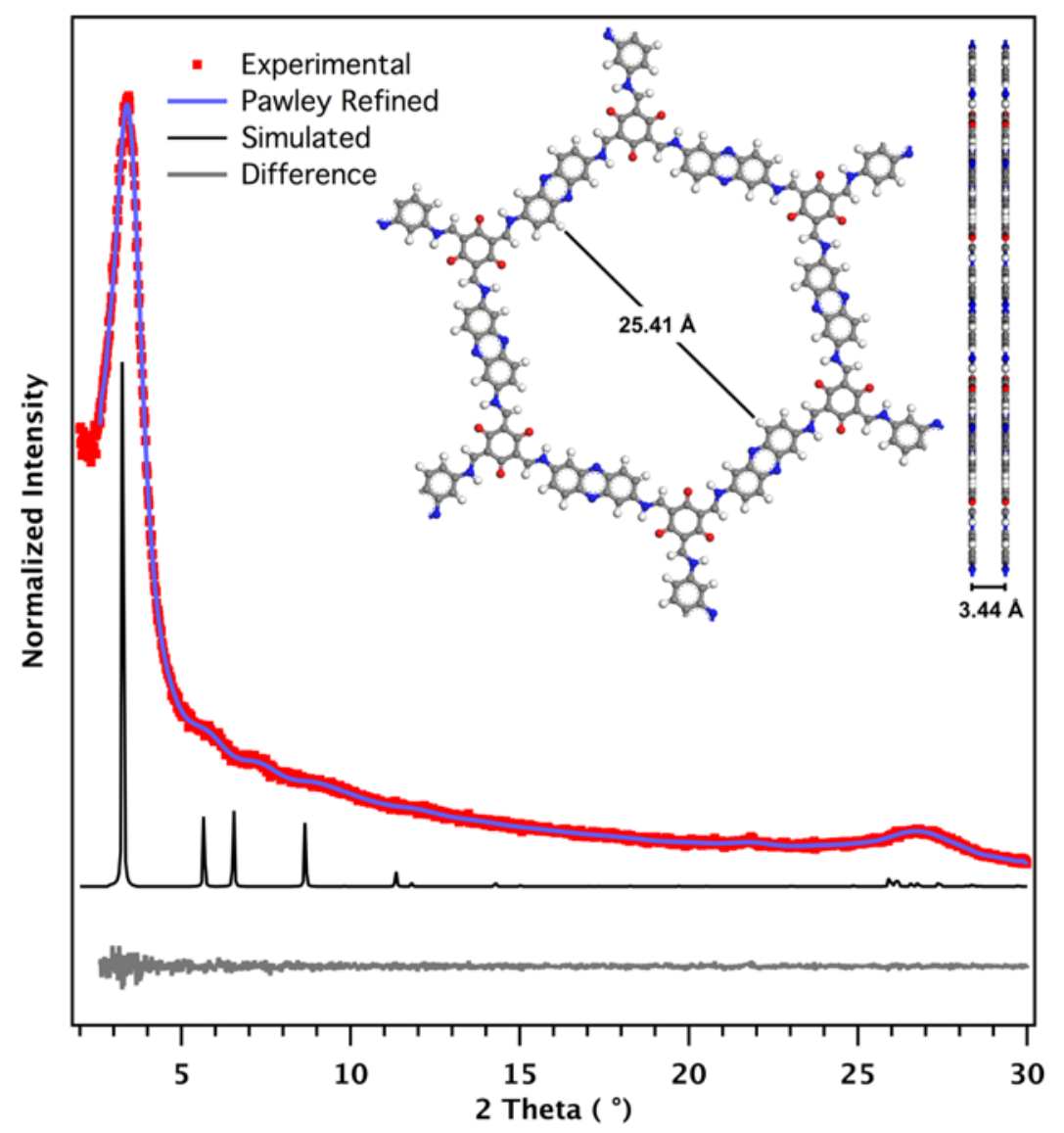

Figure S9. DAPH-TFP COF PXRD patterns for experimental (red), Pawley-refined (blue), simulated eclipsed (black), and a difference plot (gray; experimental minus refined pattern). 
Table S8. Fractional atomic coordinates for unit cell of DAAQ-TFP COF calculated using the Materials Studio modeling program. Symmetry space group $=P 6 / m$ (175); Cell length: $a=b=$ $31.5861 ; c=3.4338$.

\begin{tabular}{l|c|c|c} 
Atom & $\boldsymbol{x}$ & $\boldsymbol{y}$ & $\boldsymbol{z}$ \\
\hline $\mathrm{C} 1$ & 0.68322 & 0.38619 & 0.00000 \\
\hline C2 & 0.62960 & 0.35025 & 0.00000 \\
\hline C3 & 0.59369 & 0.36257 & 0.00000 \\
\hline N4 & 0.60054 & 0.41140 & 0.00000 \\
\hline C5 & 0.56137 & 0.42264 & 0.00000 \\
\hline C6 & 0.51151 & 0.38644 & 0.00000 \\
\hline C7 & 0.44914 & 0.46242 & 0.00000 \\
\hline C8 & 0.48770 & 0.44875 & 0.00000 \\
\hline C9 & 0.53730 & 0.48537 & 0.00000 \\
\hline C10 & 0.47530 & 0.39945 & 0.00000 \\
\hline C11 & 0.57357 & 0.47198 & 0.00000 \\
\hline O12 & 0.59386 & 0.56938 & 0.00000 \\
\hline O13 & 0.69750 & 0.42981 & 0.00000 \\
\hline H14 & 0.44344 & 0.66704 & 0.00000 \\
\hline H15 & 0.50067 & 0.65205 & 0.00000 \\
\hline H16 & 0.56264 & 0.62930 & 0.00000 \\
\hline H17 & 0.38826 & 0.49985 & 0.00000 \\
\hline H18 & 0.63516 & 0.44196 & 0.00000
\end{tabular}


Table S9. Fractional atomic coordinates for unit cell of DAPH-TFP COF calculated using the Materials Studio modeling program. Symmetry space group $=P 6 / m$ (175); Cell length: $a=b=$ $31.2053 ; c=3.4354$.

\begin{tabular}{l|c|c|c} 
Atom & $\boldsymbol{x}$ & $\boldsymbol{y}$ & $\boldsymbol{z}$ \\
\hline $\mathrm{C} 1$ & 0.68360 & 0.38688 & 0.00000 \\
\hline $\mathrm{C} 2$ & 0.62929 & 0.35063 & 0.00000 \\
\hline $\mathrm{C} 3$ & 0.59307 & 0.36327 & 0.00000 \\
\hline $\mathrm{N} 4$ & 0.60019 & 0.41278 & 0.00000 \\
\hline C5 & 0.56067 & 0.42432 & 0.00000 \\
\hline C6 & 0.50997 & 0.38766 & 0.00000 \\
\hline N7 & 0.45098 & 0.46395 & 0.00000 \\
\hline C8 & 0.48636 & 0.45069 & 0.00000 \\
\hline C9 & 0.53662 & 0.48764 & 0.00000 \\
\hline C10 & 0.47329 & 0.40093 & 0.00000 \\
\hline C11 & 0.57329 & 0.47443 & 0.00000 \\
\hline O12 & 0.69820 & 0.43105 & 0.00000 \\
\hline H13 & 0.44457 & 0.66660 & 0.00000 \\
\hline H14 & 0.50245 & 0.65132 & 0.00000 \\
\hline H15 & 0.56533 & 0.62763 & 0.00000 \\
\hline H16 & 0.38820 & 0.49669 & 0.00000 \\
\hline H17 & 0.63527 & 0.44365 & 0.00000
\end{tabular}




\section{Powder X-ray Diffraction Data}

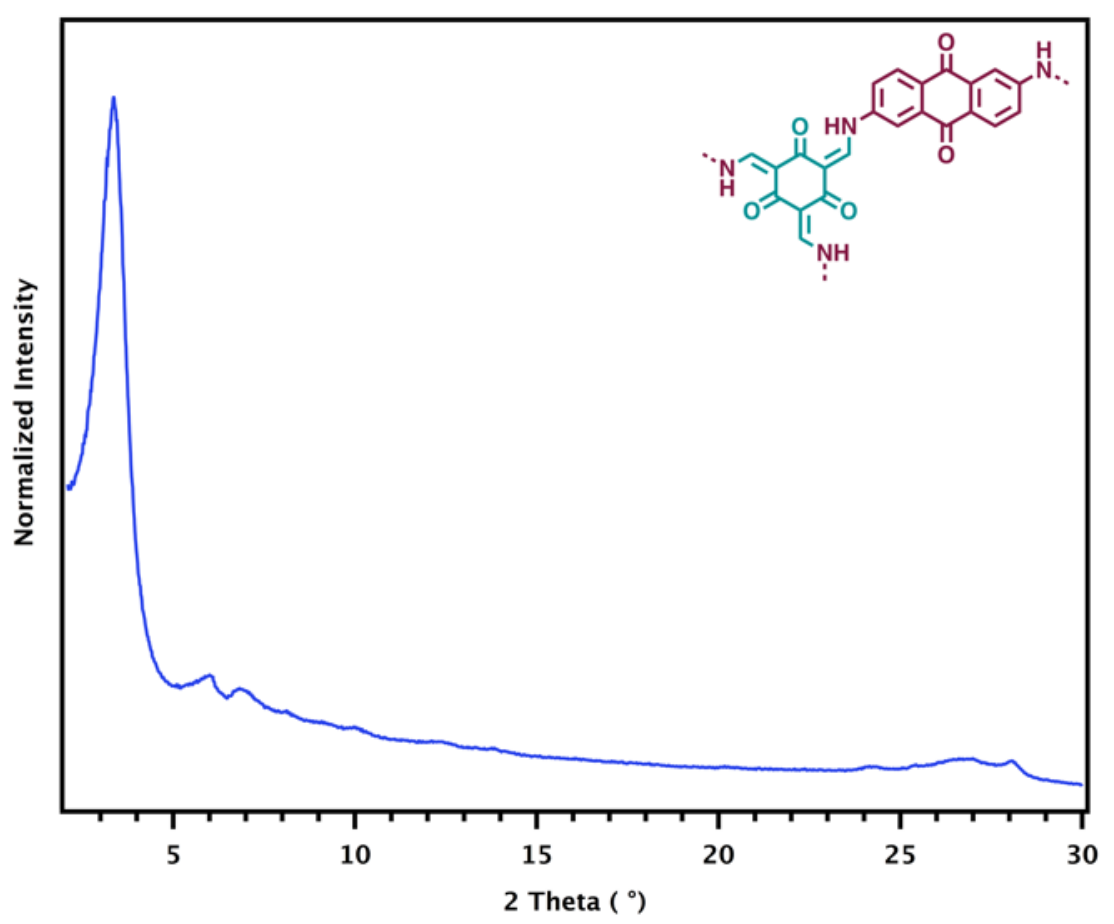

Figure S10. PXRD pattern for DAAQ-TFP COF.

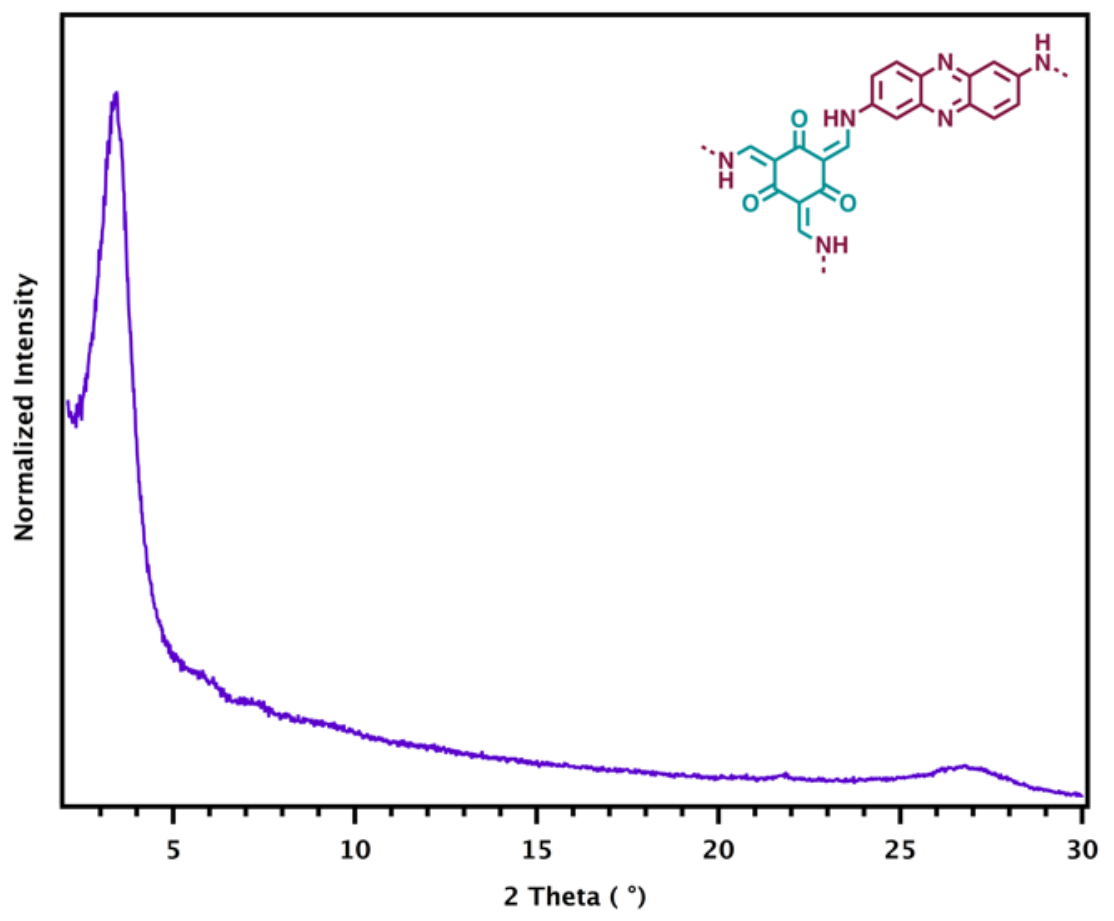

Figure S11. PXRD pattern for DAPH-TFP COF. 


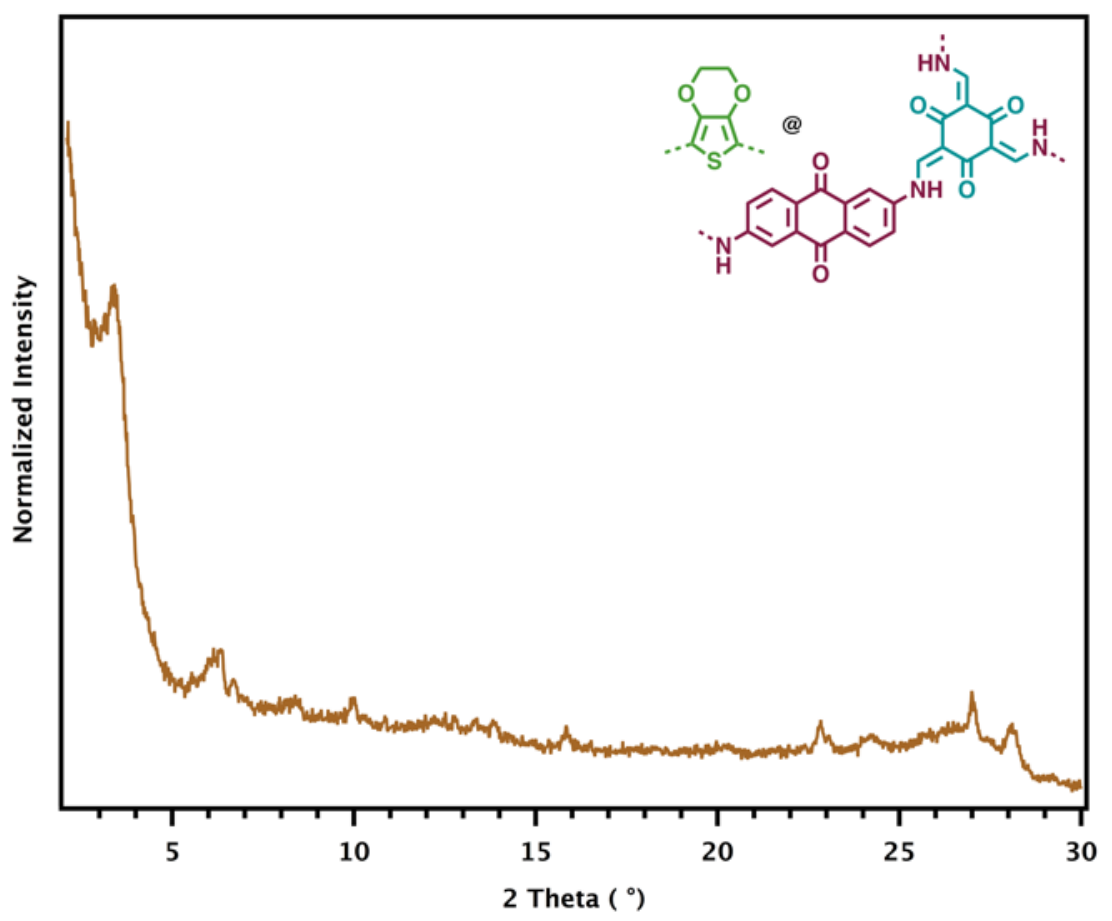

Figure S12. PXRD pattern for PEDOT@DAAQ-TFP COF.

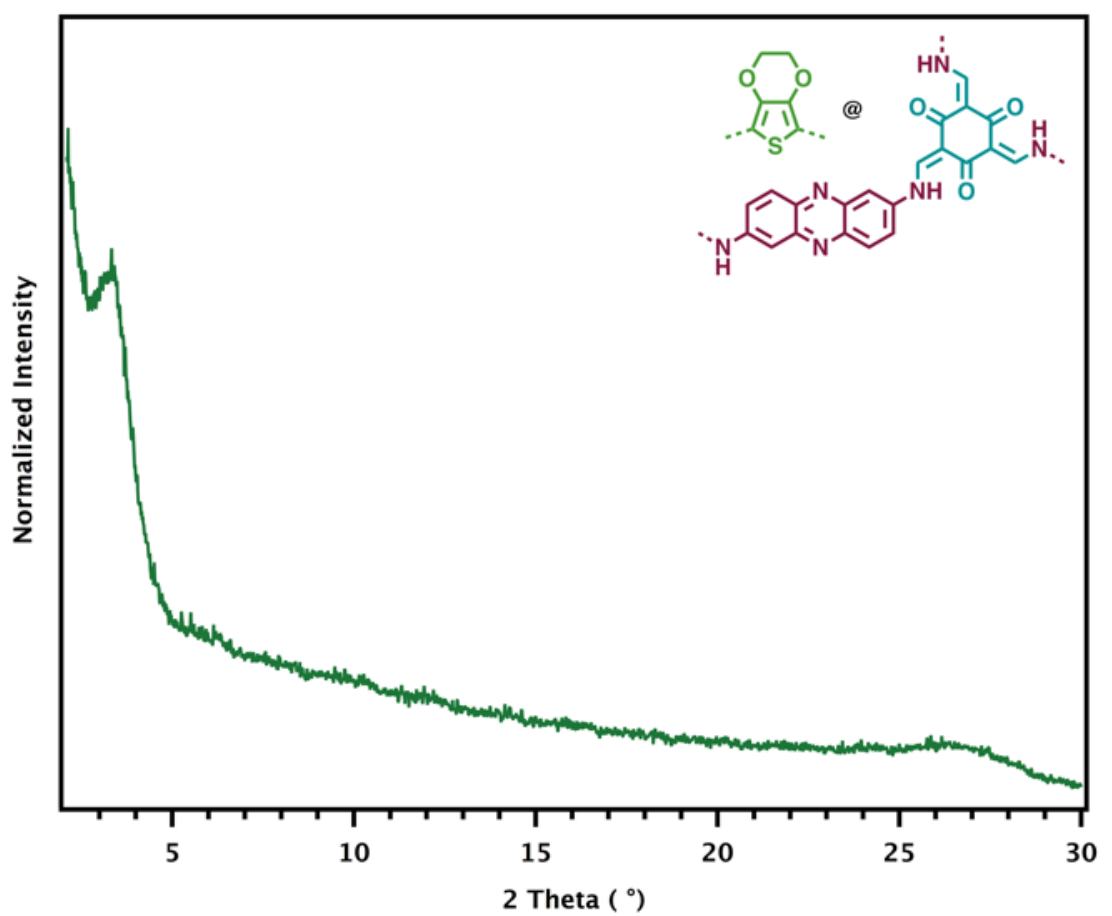

Figure S13. PXRD pattern for PEDOT@DAPH-TFP COF. 


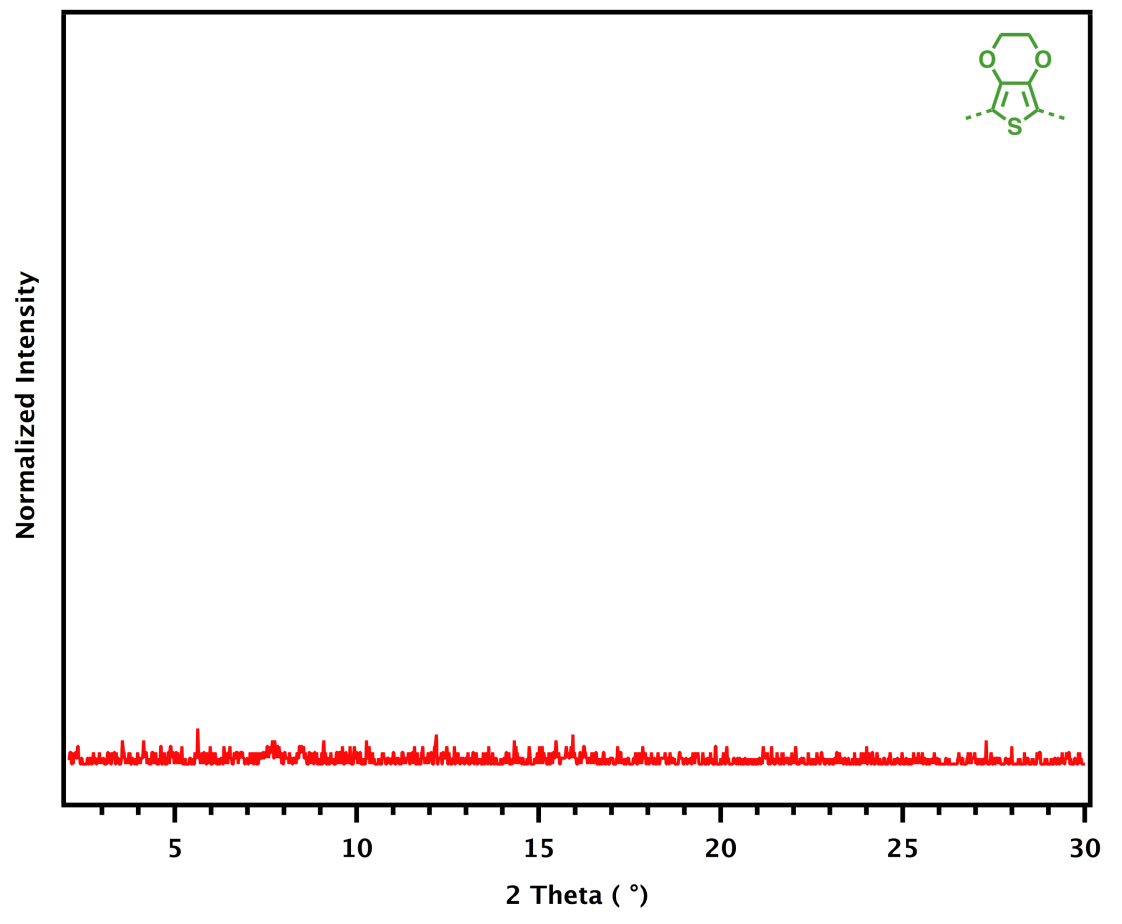

Figure S14. PXRD pattern for bare PEDOT. 


\section{VIII.Surface Area and Porosity Measurements}
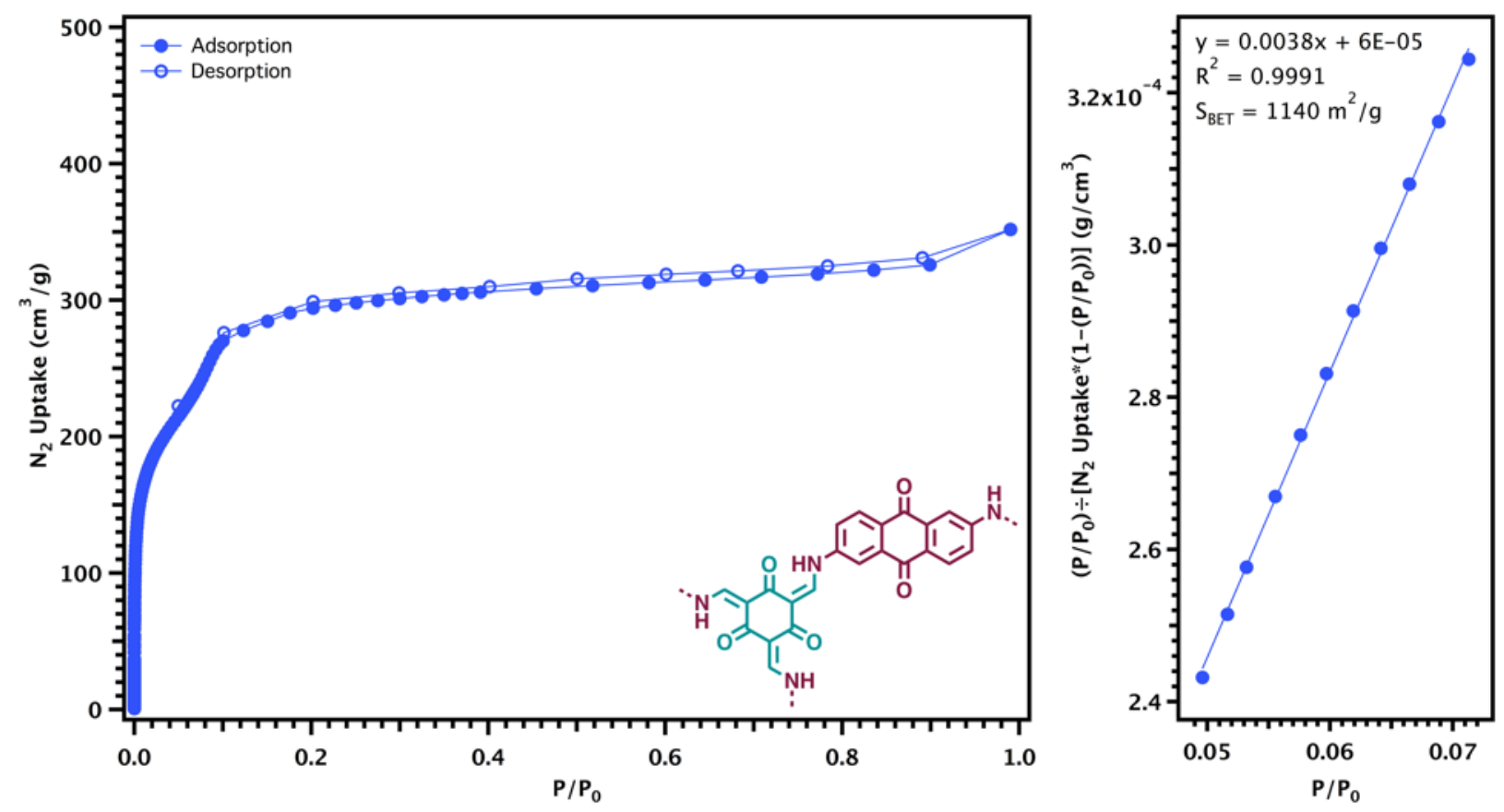

Figure S15. (Left) Adsorption Isotherm and (Right) BET surface area plot for DAAQ-TFP COF.
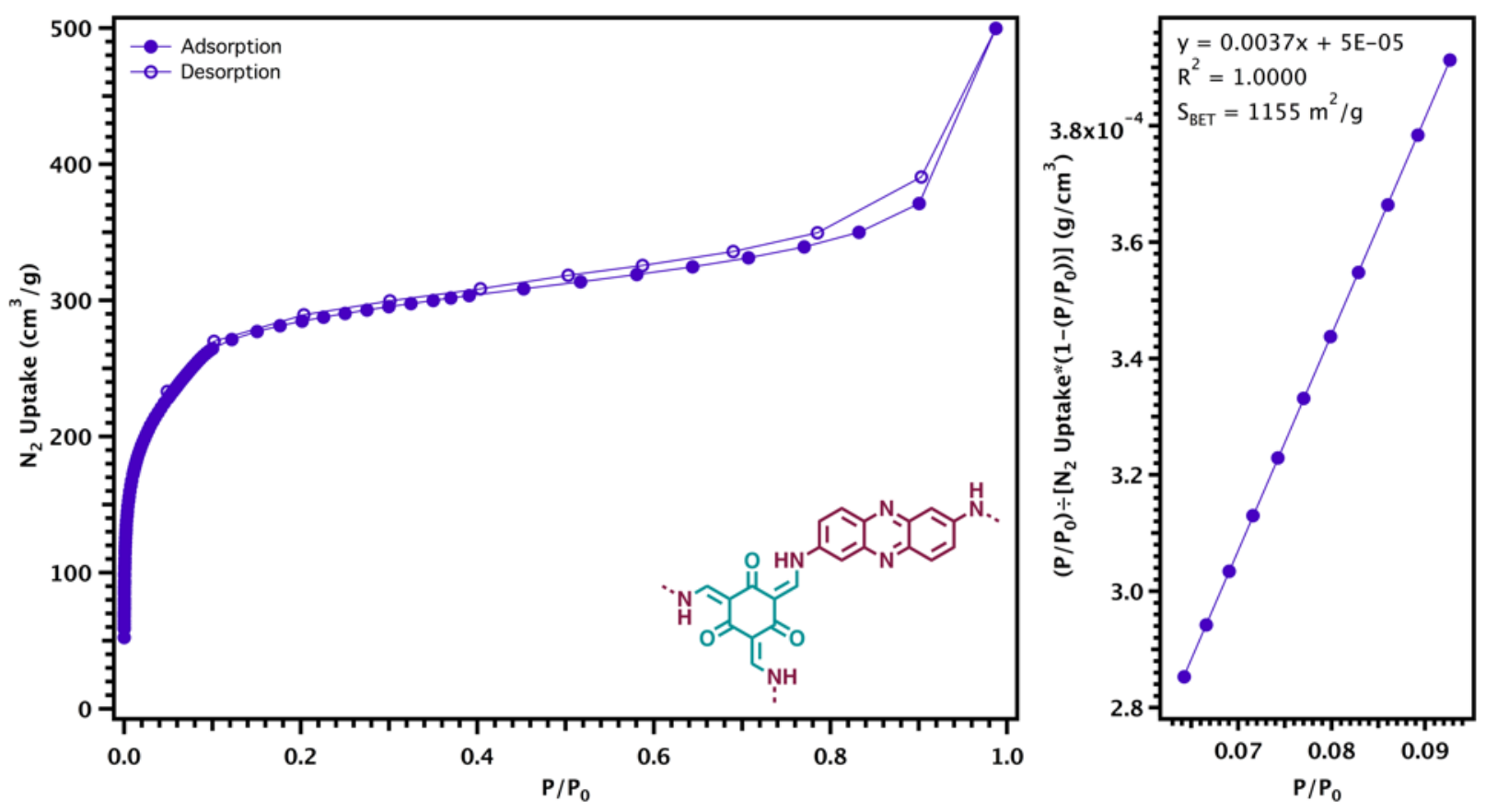

Figure S16. (Left) Adsorption Isotherm and (Right) BET surface area plot for DAPH-TFP COF. 

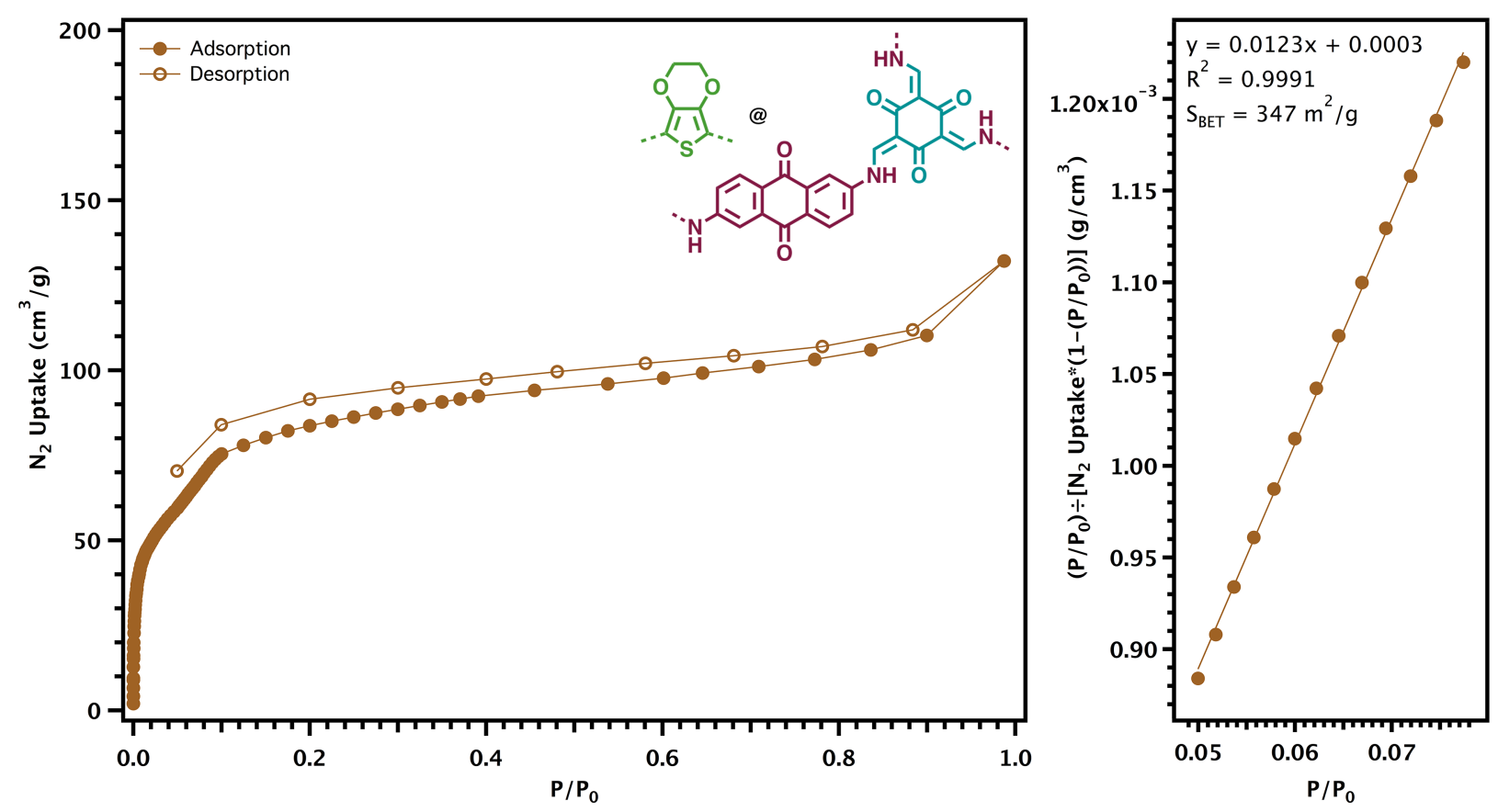

Figure S17. (Left) Adsorption Isotherm and (Right) BET surface area plot for PEDOT@DAAQTFP COF.
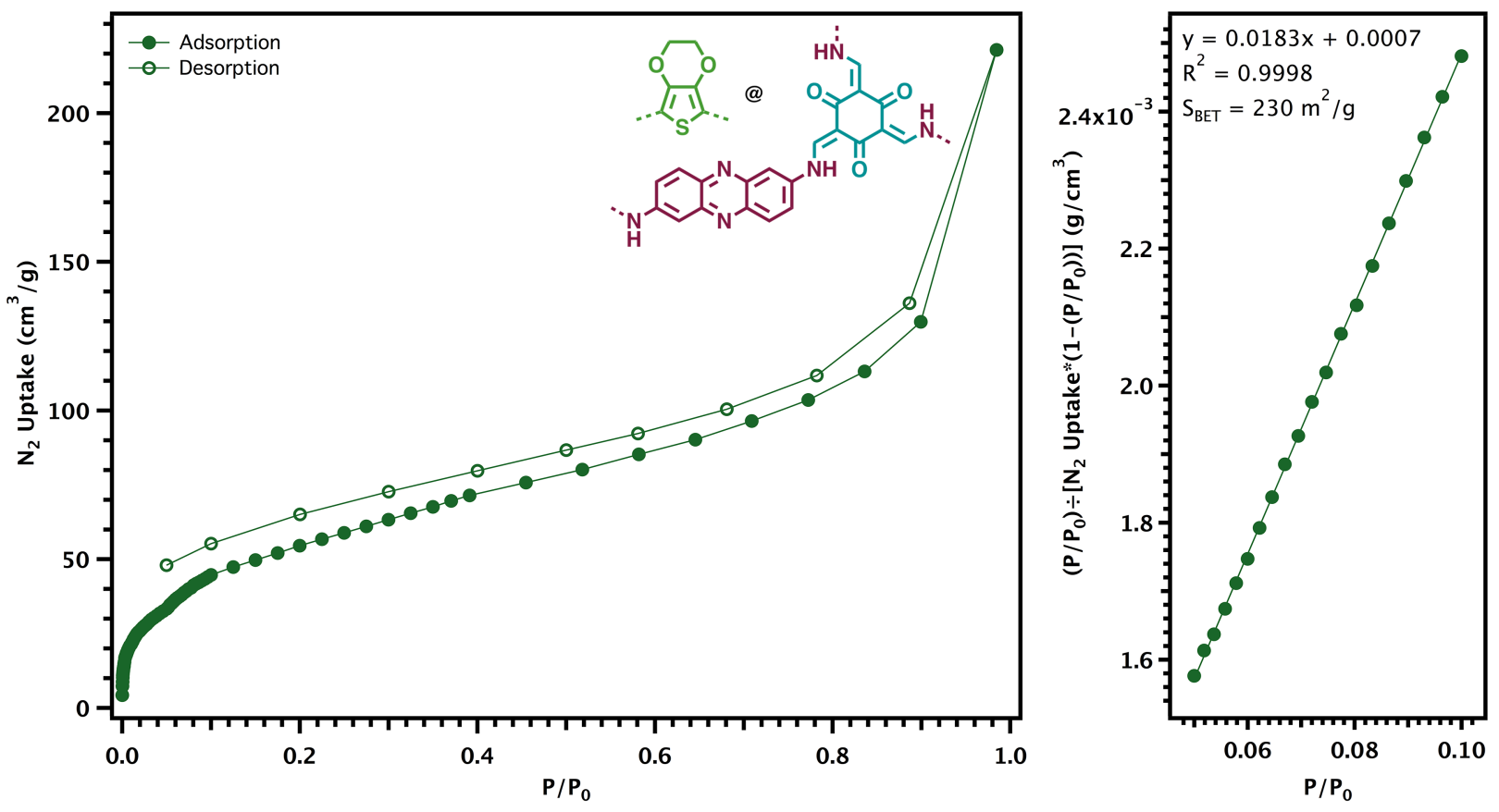

Figure S18. (Left) Adsorption Isotherm and (Right) BET surface area plot for PEDOT@DAPHTFP COF. 


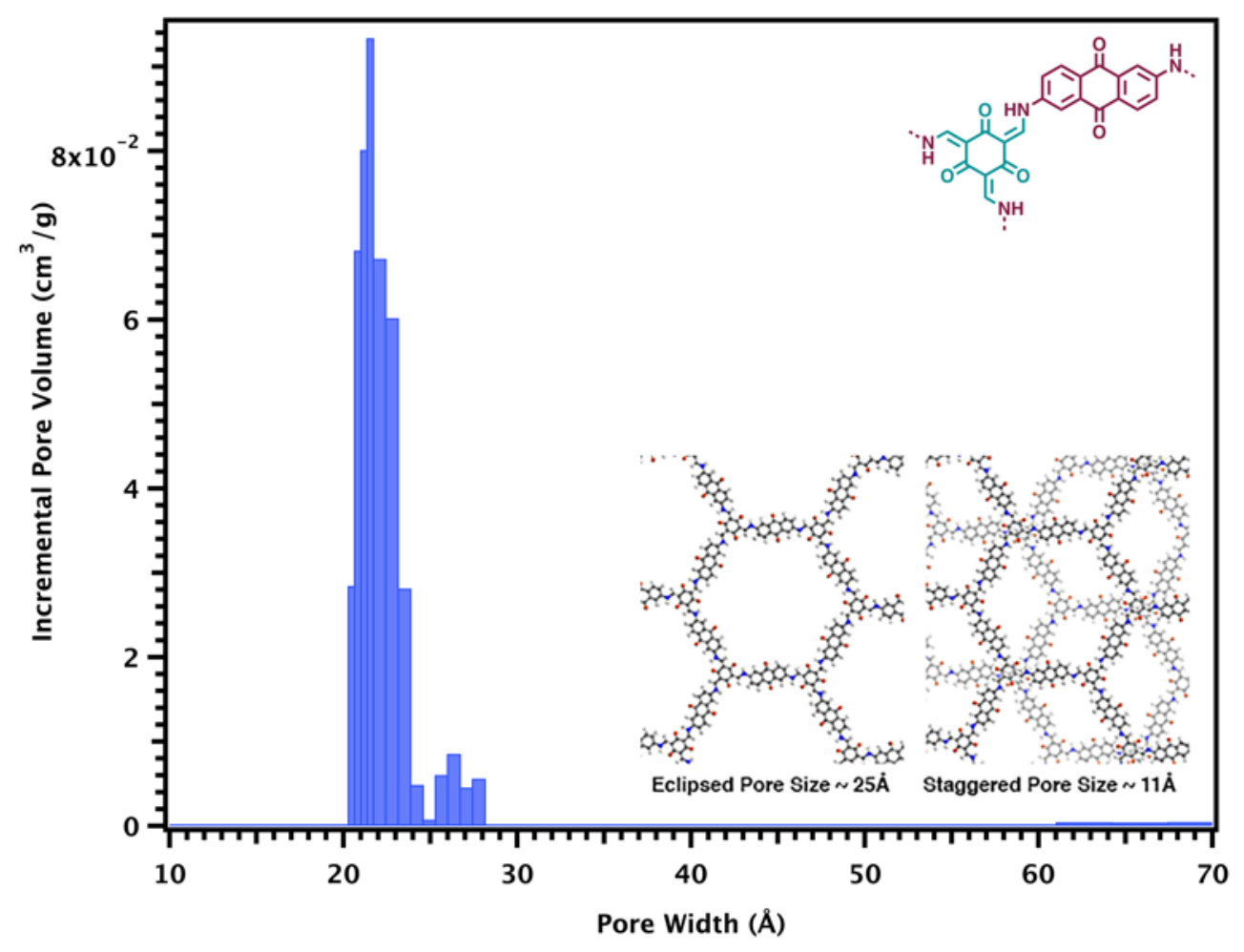

Figure S19. Pore size distribution of DAAQ-TFP COF (also confirms an eclipsed structure).

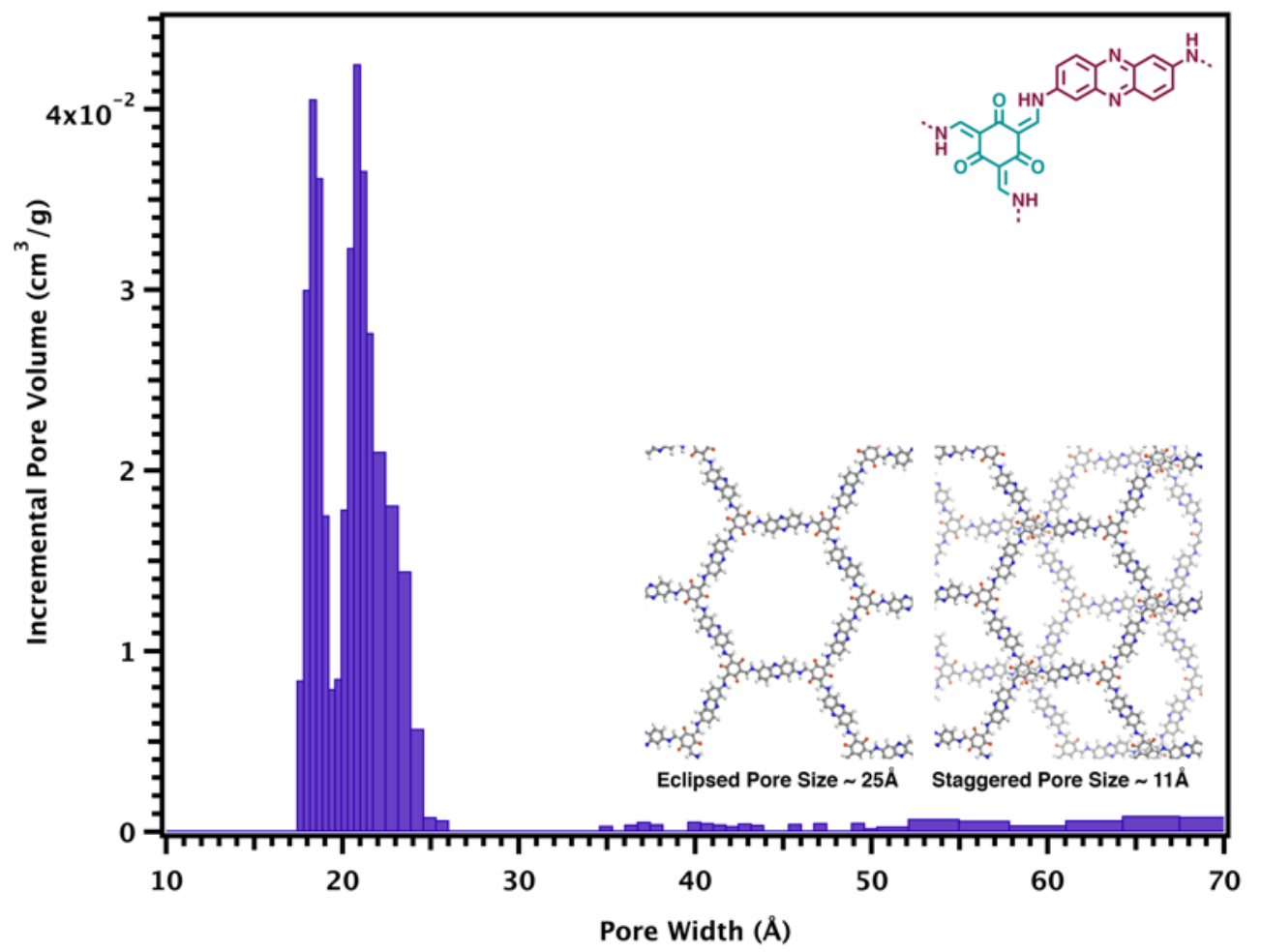

Figure S20. Pore size distribution of DAPH-TFP COF (also confirms an eclipsed structure). 


\section{Thermogravimetric Analysis}

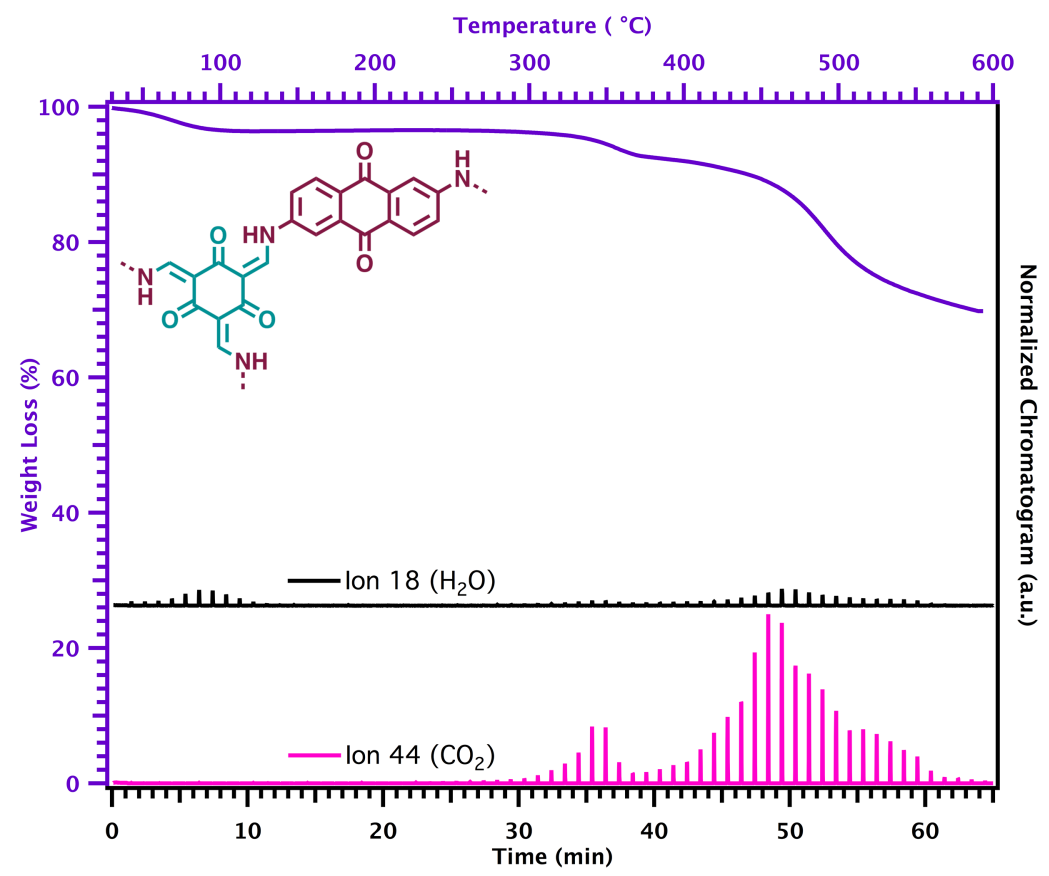

Figure S21. TGA-GCMS of DAAQ-TFP COF with extracted Ion-18 and Ion-44 from the chromatogram.

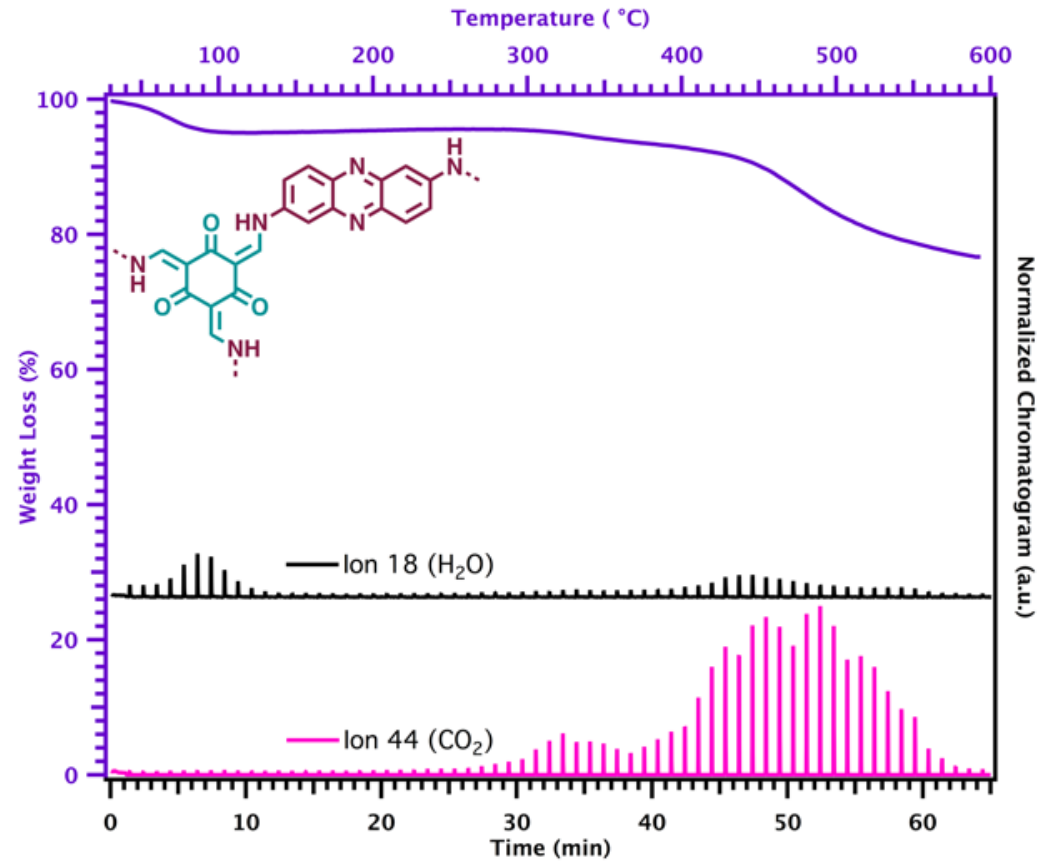

Figure S22. TGA-GCMS of DAPH-TFP COF with extracted Ion-18 and Ion-44 from the chromatogram. 


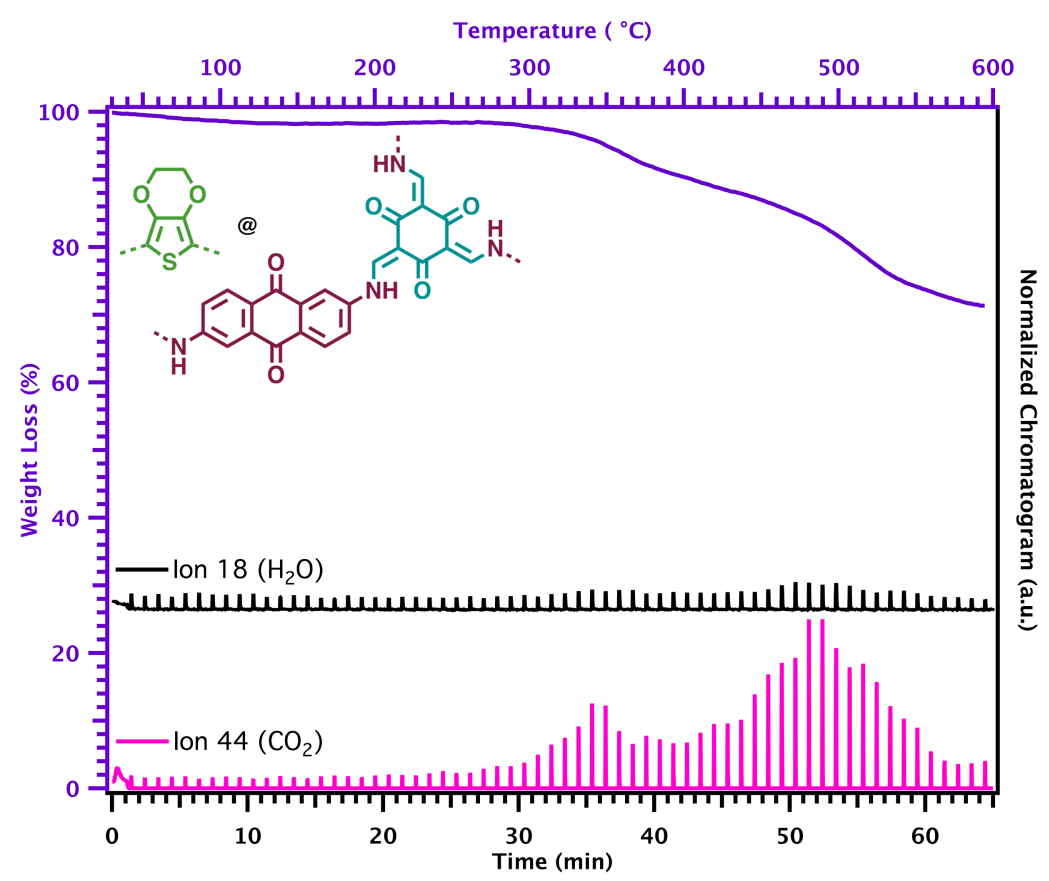

Figure S23. TGA-GCMS of PEDOT@DAAQ-TFP COF with extracted Ion-18 and Ion-44 from the chromatogram.

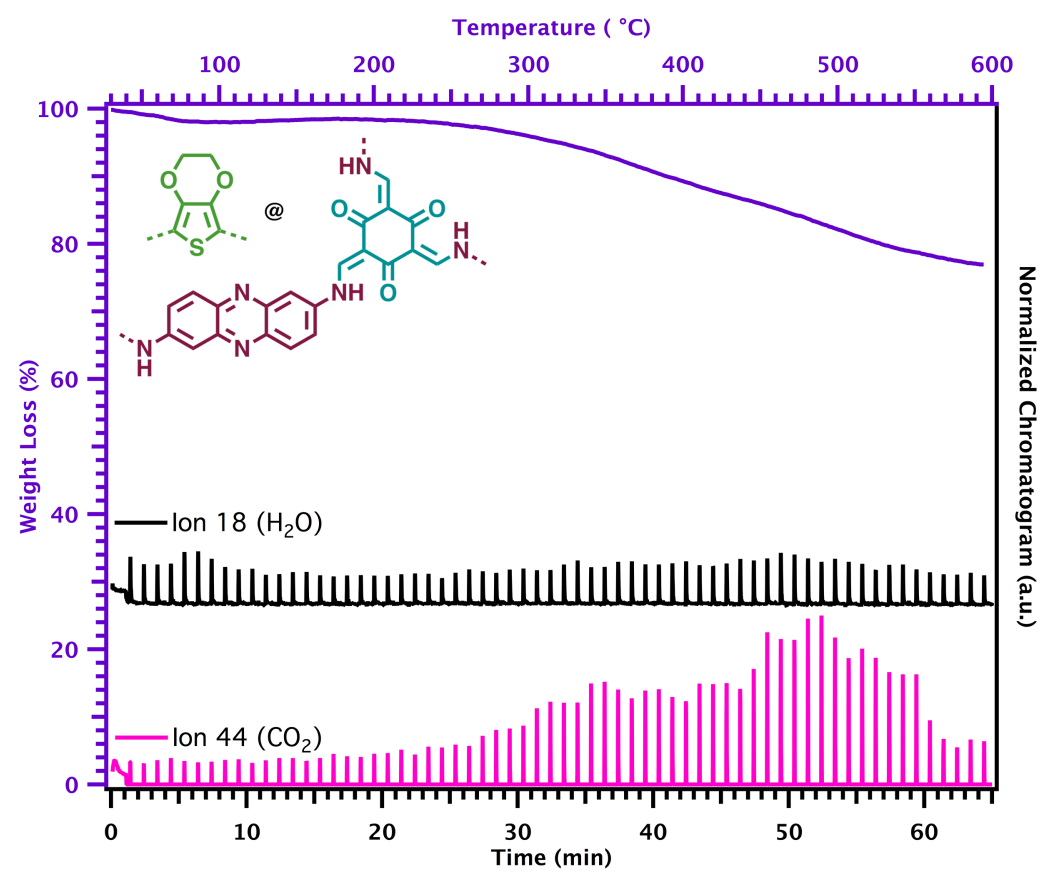

Figure S24. TGA-GCMS of PEDOT@DAPH-TFP COF with extracted Ion-18 and Ion-44 from the chromatogram. 


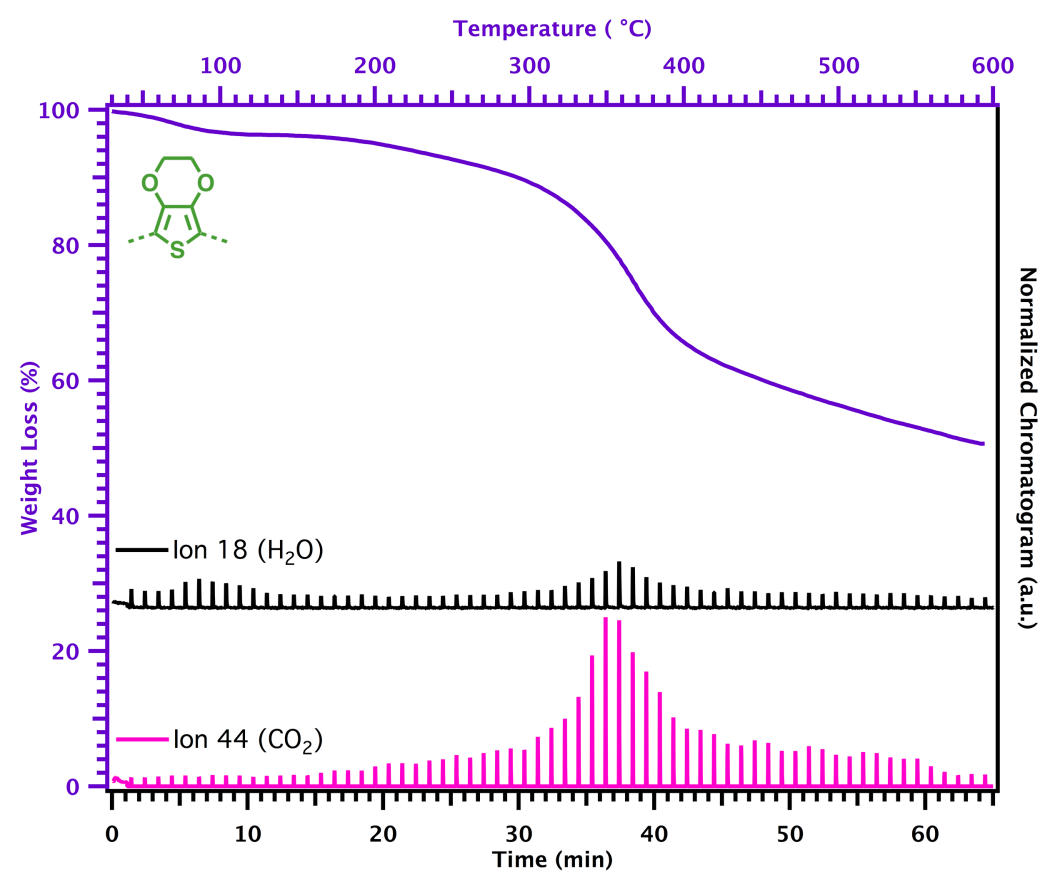

Figure S25. TGA-GCMS of bare PEDOT with extracted Ion-18 and Ion-44 from the chromatogram. 


\section{Scanning Electron Microscopy}

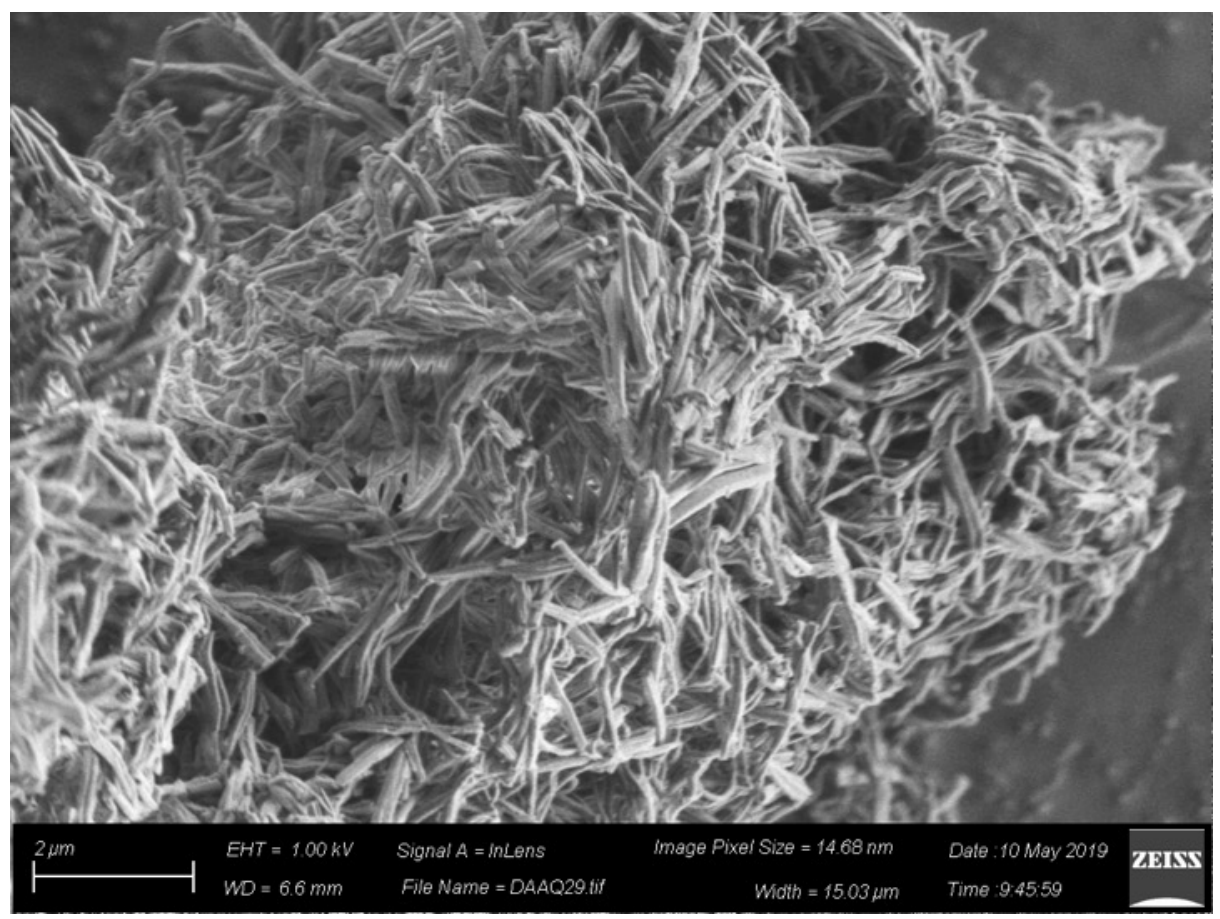

Figure S26. SEM image of DAAQ-TFP COF.

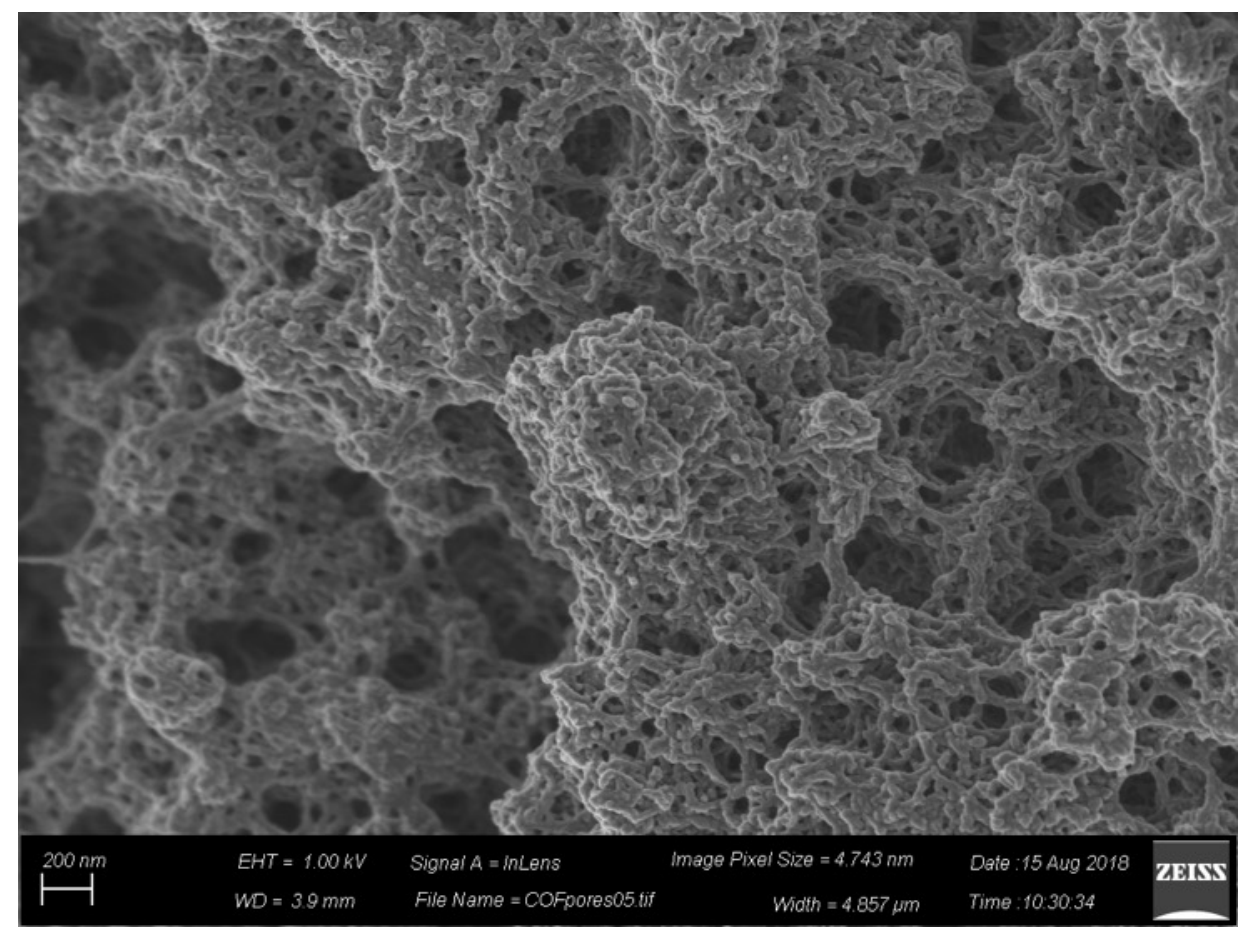

Figure S27. SEM image of DAPH-TFP COF. 


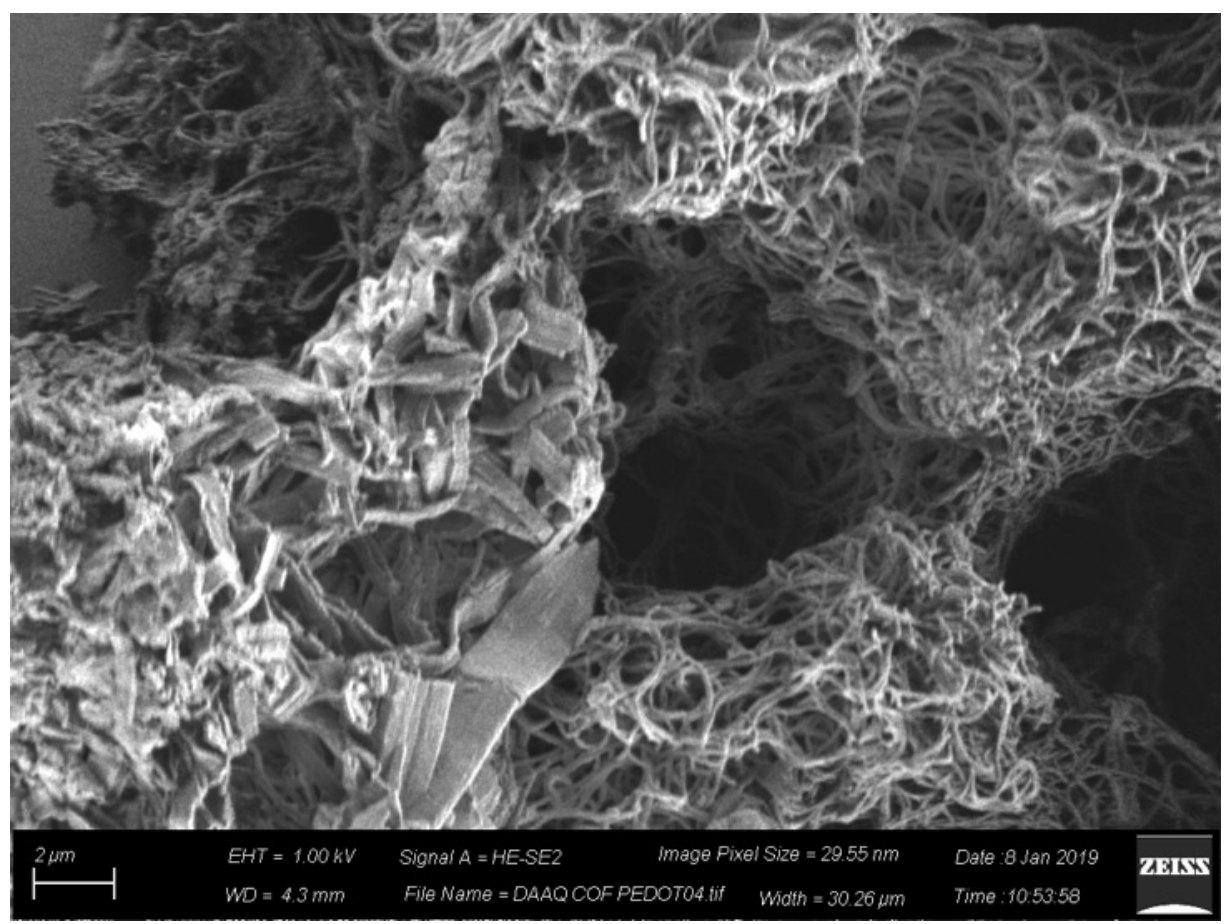

Figure S28. SEM image of PEDOT@DAAQ-TFP COF.

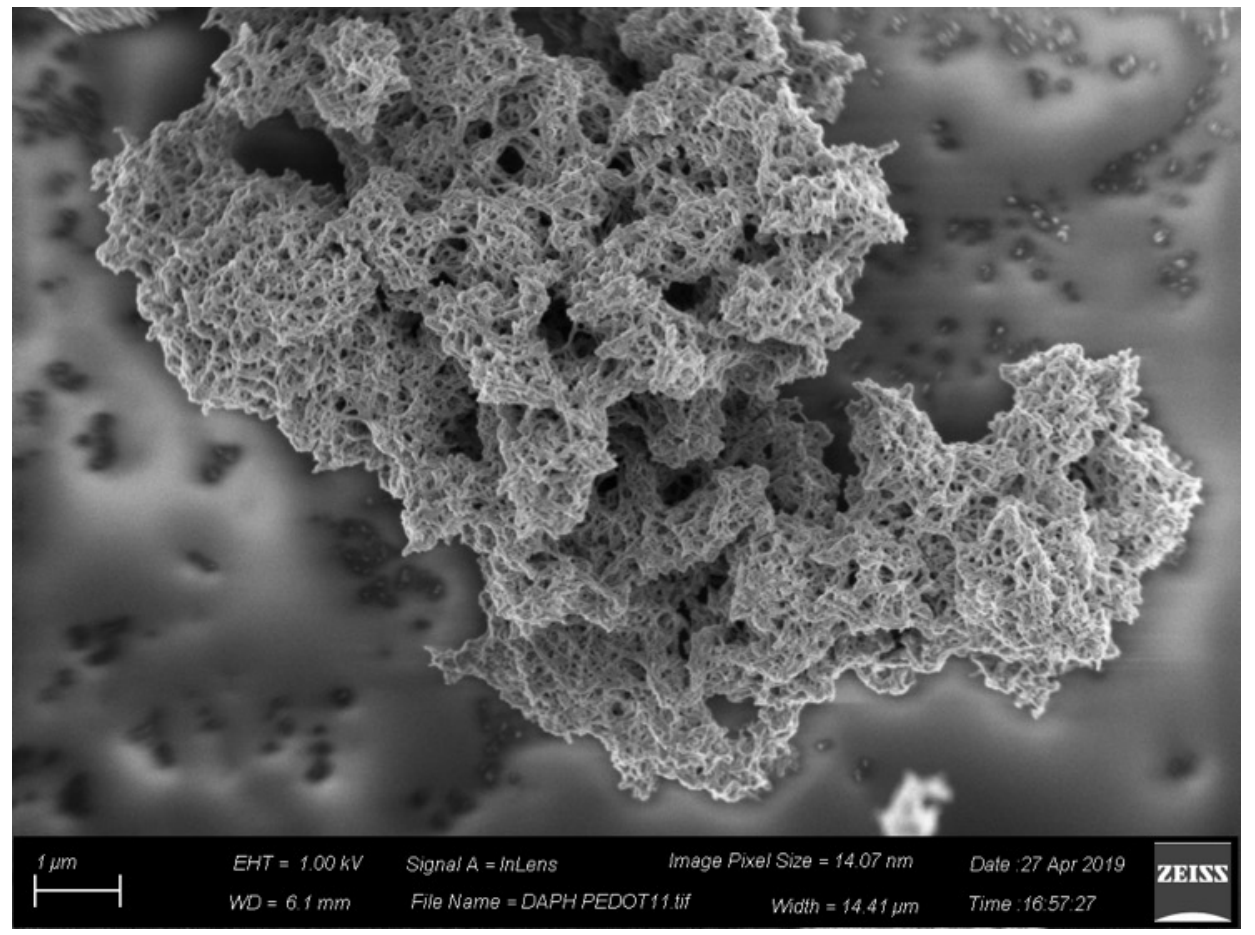

Figure S29. SEM image of PEDOT@DAPH-TFP COF. 


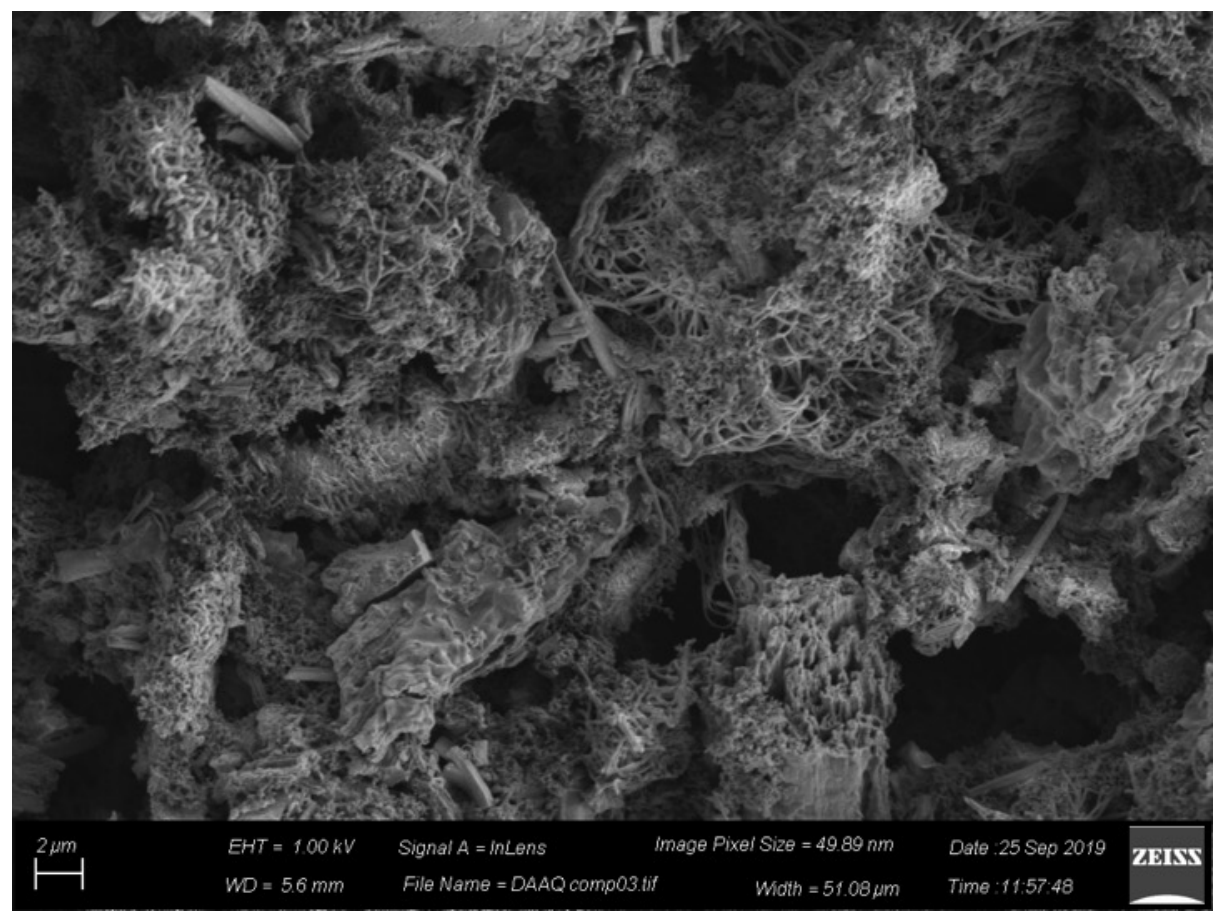

Figure S30. SEM image of DAAQ-TFP COF incorporated into a cathode composite (with Super P carbon, CMK-3 carbon, and PVDF binder), dried on a carbon paper current collector.

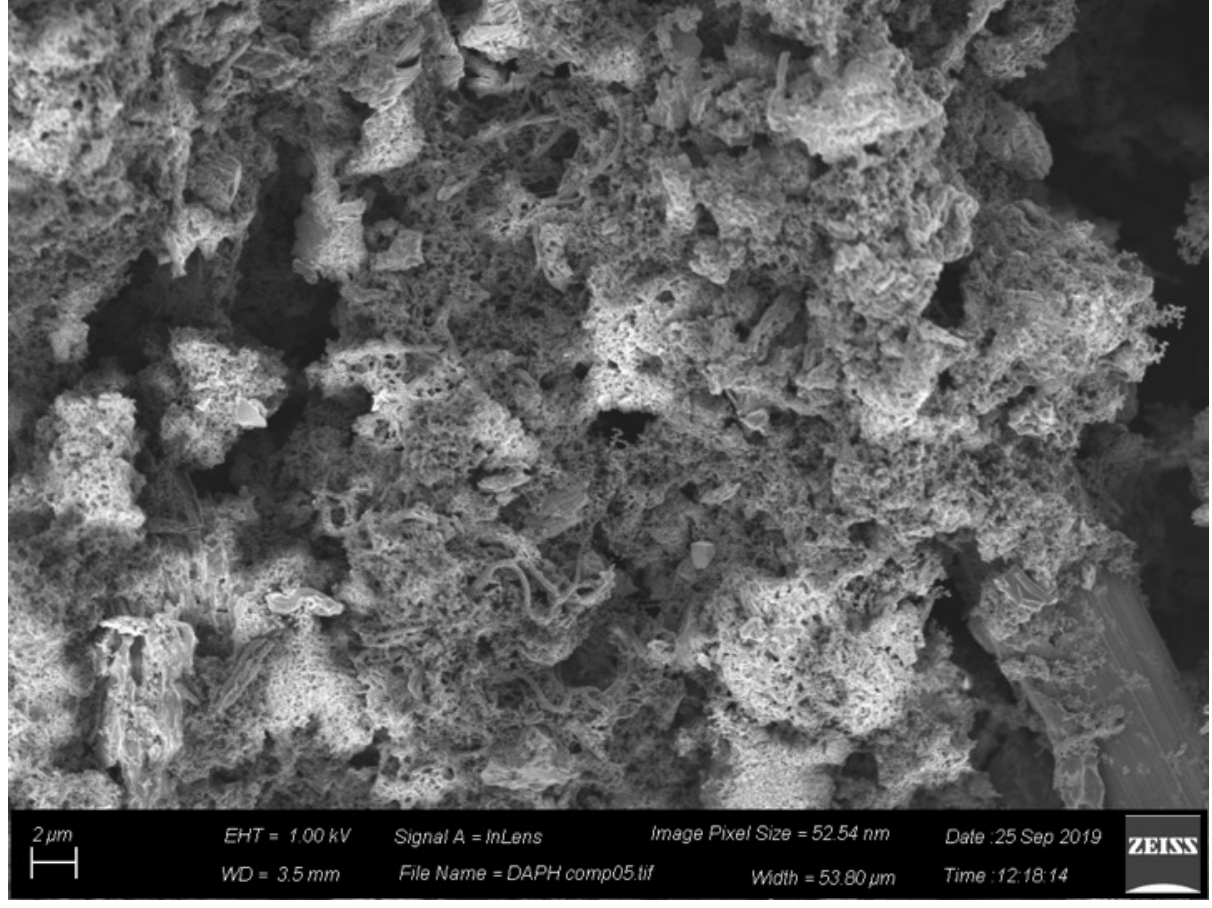

Figure S31. SEM image of DAPH-TFP COF incorporated into a cathode composite on a carbon paper current collector. 


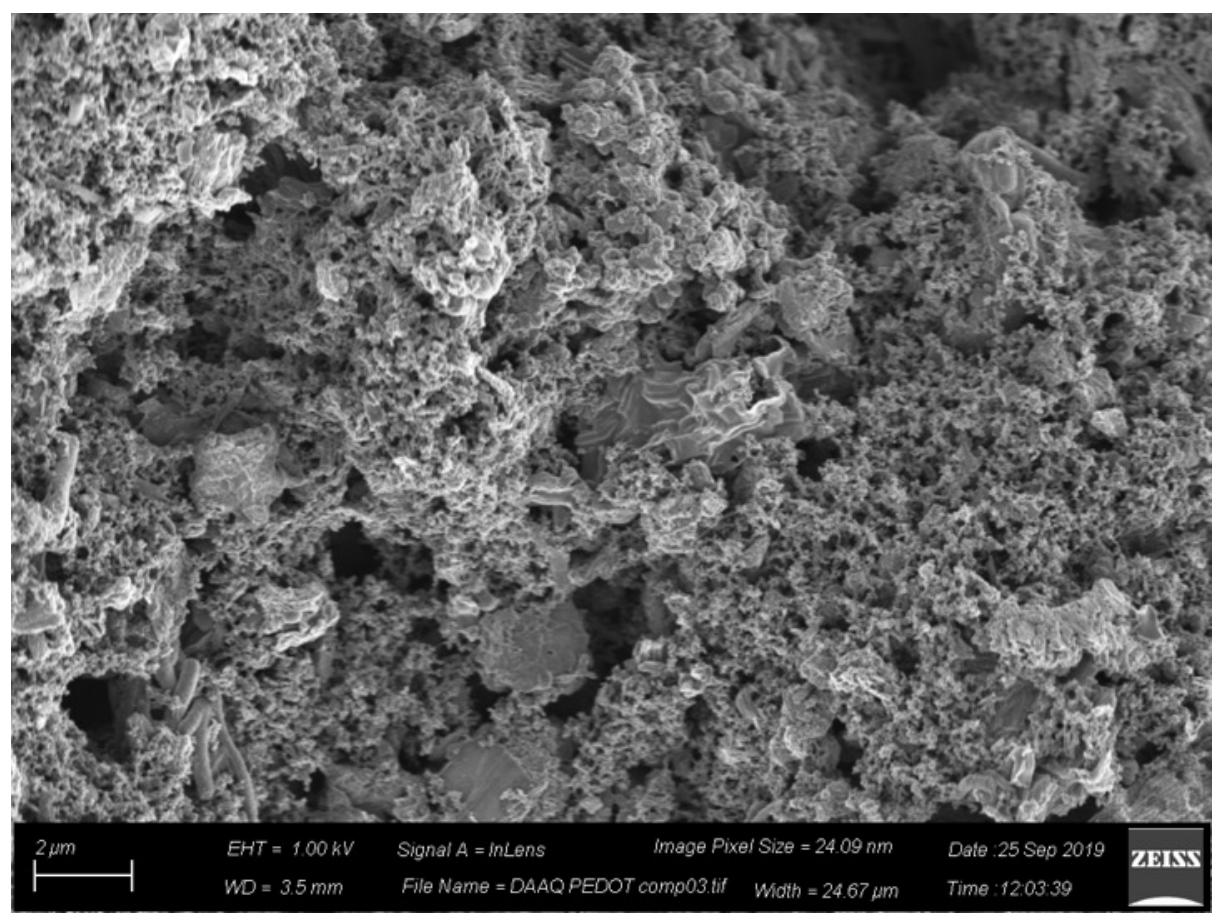

Figure S32. SEM image of PEDOT@DAAQ-TFP COF incorporated into a cathode composite on a carbon paper current collector.

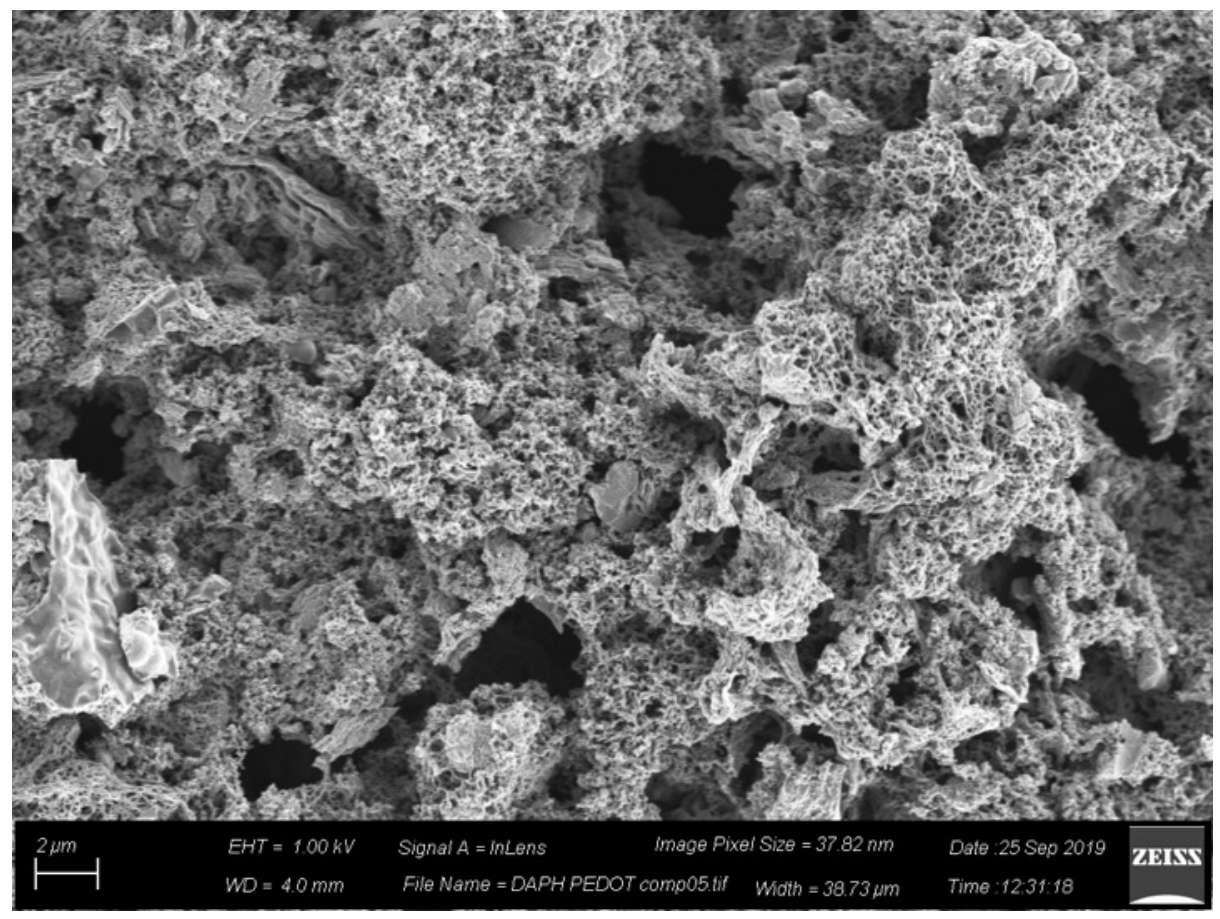

Figure S33. SEM image of PEDOT@DAPH-TFP COF incorporated into a cathode composite on a carbon paper current collector. 


\section{Energy Dispersive X-ray Elemental Mapping}

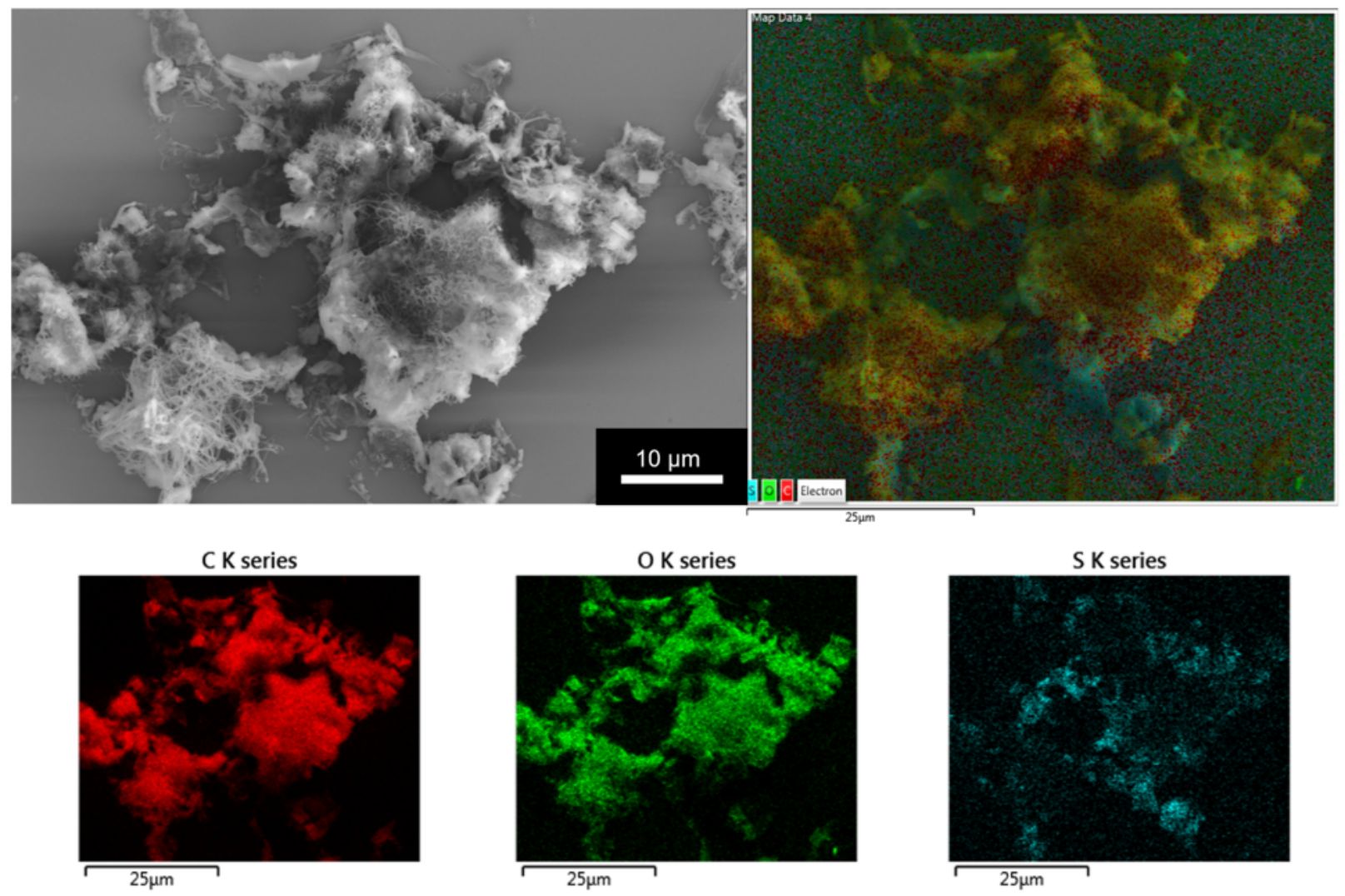

Figure S34. Elemental mapping of carbon, oxygen, and sulfur in PEDOT@DAAQ-TFP COF sample. Sulfur map represents the distribution of PEDOT throughout the COF sample. 

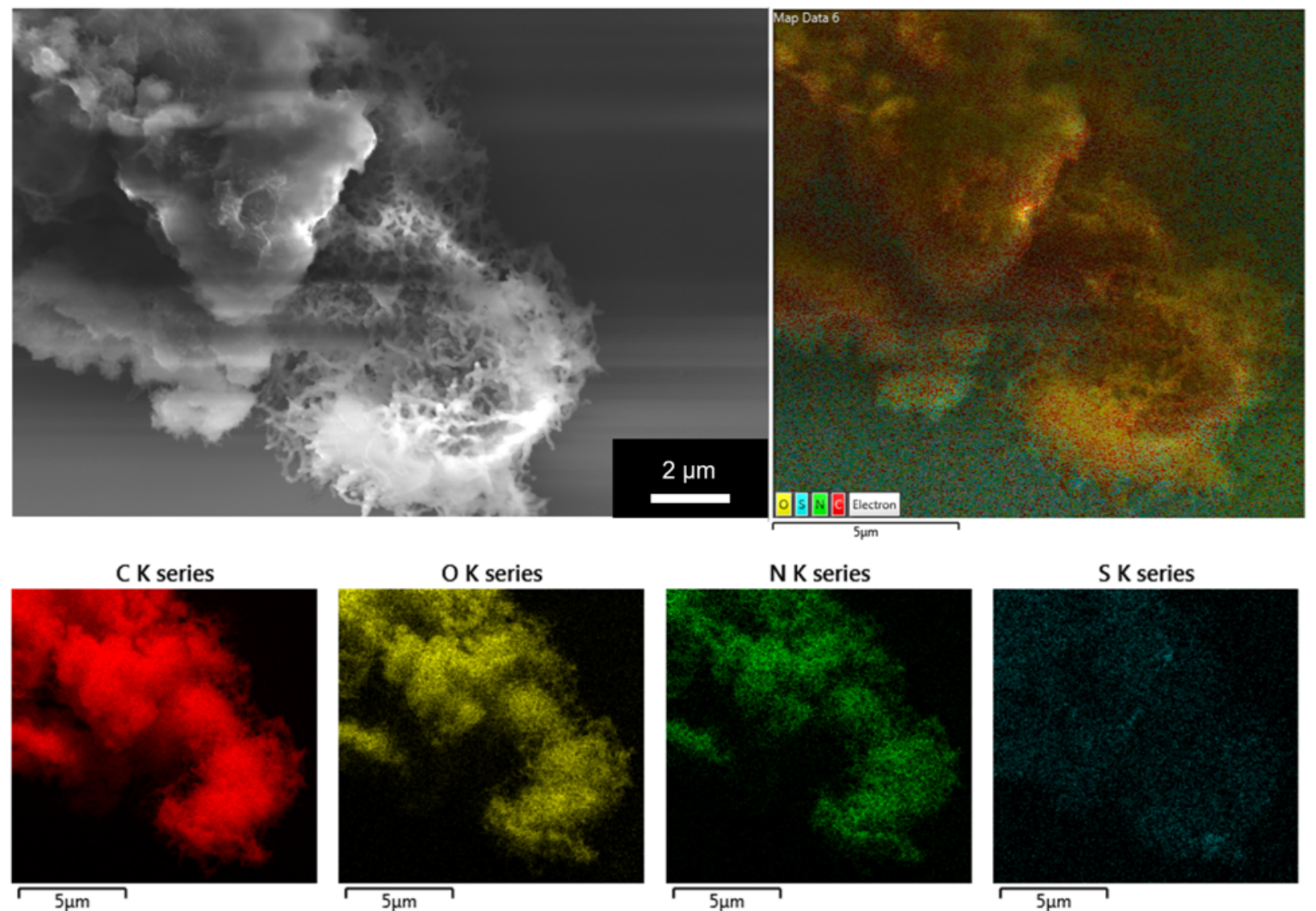

Figure S35. Elemental mapping of carbon, oxygen, nitrogen, and sulfur in PEDOT@DAPH-TFP COF sample. Sulfur map represents the distribution of PEDOT throughout the COF sample. 


\section{Electrochemical Methods and Data}

\section{Device Testing}

Coin Cell Assembly. The cathode composites were fabricated from a slurry of $60 \mathrm{wt} \%$ active material, $15 \mathrm{wt} \%$ Super P carbon (Imerys Graphite \& Carbon), 15 wt\% CMK-3 mesoporous carbon (ACS materials), and $10 \mathrm{wt} \%$ poly(vinylidene fluoride) (PVDF) (Kynar Flex) as the binder in NMP (anhydrous 99.5\%, Sigma-Aldrich). Super P and PVDF were dried overnight in a vacuum oven at $60{ }^{\circ} \mathrm{C}$ and stored in a desiccator before use. A doctor blade with one layer of scotch tape was used to spread the slurry onto a carbon paper current collector (Fuel Cell Store). The coated electrode was dried for $2 \mathrm{~h}$ at $60^{\circ} \mathrm{C}$ followed by overnight at $110^{\circ} \mathrm{C}$ in a vacuum oven. The average active material loading was $0.80 \mathrm{mg} / \mathrm{cm}^{2}$. Average thickness of the electrode was approximately $100 \mu \mathrm{m}$. Due to some of the composite slurry soaking into the carbon paper current collector, a measurement of the thickness of just the composite, without the thickness of the carbon paper, was not possible.

CR 2032 coin cells were assembled in an argon filled glove box with water levels below $0.50 \mathrm{ppm}$. Lithium metal (Alfa Aesar, $0.75 \mathrm{~mm}, 99.9 \%$, punched to $9 / 16$ inch disks) served as the anode. A dried glass microfiber filter (GF/A, Whatman) was used as the separator between the two electrodes. The electrolyte solution was 1:1 by volume of EC (ethylene carbonate) ( $99+\%$, Aldrich) to DEC (diethyl carbonate) (99+\%, Aldrich) with $1 \mathrm{M} \mathrm{LiPF}_{6}(98+\%$, Aldrich). To each coin cell, $80 \mu \mathrm{L}$ of the electrolyte solution was added. A Neware battery tester was used to perform galvanostatic charge-discharge experiments on the coin cells over the voltage range of $1.4 \mathrm{~V}$ to 3.6 $\mathrm{V}$ vs. $\mathrm{Li} / \mathrm{Li}^{+}$at $25^{\circ} \mathrm{C}$. For cycling measurements, a constant charge-discharge current rate of $1 \mathrm{C}$ was used. To evaluate rate performance, the cells were charged at $0.5 \mathrm{C}$ and discharged at the indicated C-rate. Performance of each material was determined as an average capacity obtained from at least three coin cells for each test.

Capacity Calculation. The theoretical capacities of DAAQ-TFP COF and DAPH-TFP COF were calculated using Eq. (1):

$$
C_{\text {theor }}=\frac{n F}{3600\left(\frac{M_{W}}{1000}\right)}
$$


where $n$ is the number of electrons that each repeat unit can be reduced by ( 2 electrons), $F$ is Faraday's constant ( $96485 \mathrm{C} \mathrm{mol}^{-1}$ ), and $M_{\mathrm{w}}$ is the molar mass of repeating unit in the COF. The theoretical capacity of DAAQ-TFP COF is $157 \mathrm{mAh} / \mathrm{g}$ and the theoretical capacity of DAPH-TFP COF is $171 \mathrm{mAh} / \mathrm{g}$. The specific capacity of the materials was calculated by Eq. (2):

$$
C_{s p}=\frac{i_{a p p l} \cdot t}{m_{C O F}}
$$

Where $i_{a p p l}$ is the applied current, $t$ is the time the current was sustained before reaching the voltage limit, and $m_{C O F}$ is the mass of the DAAQ-TFP COF or DAPH-TFP COF present in the cell.

C-rates used for testing of cells correspond with a current density sufficient to charge/discharge the theoretical capacity of the material in a designated time, such that $1 \mathrm{C}$ corresponds to discharging the battery its theoretical capacity in 1 hour. Thus, $1 \mathrm{C}$ corresponded to a discharge current of $157 \mathrm{~mA} / \mathrm{g}$ and $171 \mathrm{~mA} / \mathrm{g}$ for DAAQ-TFP COF and DAPH-TFP COF, respectively. At an average mass loading of $0.8 \mathrm{mg} / \mathrm{cm}^{2}$, these gravimetric current densities correspond to areal current densities of $0.126 \mathrm{~mA} / \mathrm{cm}^{2}$ and $0.137 \mathrm{~mA} / \mathrm{cm}^{2}$ for DAAQ-TFP COF and DAPH-TFP COF, respectively.

Diffusion Coefficient Analysis. CV was performed on the assembled coin cells of each of the COF materials to obtain diffusion coefficients of the $\mathrm{Li}^{+}$ions through the solid-state electrode material. The cell was scanned at rates from $0.5 \mathrm{mV} / \mathrm{s}$ to $20 \mathrm{mV} / \mathrm{s}$. Using the Randles-Sevcik equation (Eq. 3$)^{8}$ the diffusion coefficient was obtained from the slope of a plot of peak current vs. square root of scan rate:

$$
i_{p}=0.4463 n F A C\left(\frac{n F v D}{R T}\right)^{1 / 2}
$$

Where $n$ is the number of electrons transferred ( 2 electrons), $A$ is the electrode surface area in $\mathrm{cm}^{2}$, $C$ is the concentration of the $\mathrm{Li}^{+}$in $\mathrm{mol} / \mathrm{cm}^{3}, v$ is the scan rate in $\mathrm{V} / \mathrm{s}, i_{\mathrm{p}}$ is the peak current in Amperes, $D$ is the diffusion coefficient in $\mathrm{cm}^{2} / \mathrm{s}$, and $\mathrm{F}, \mathrm{R}$, and $\mathrm{T}$ have their usual meanings.

Energy Density Calculation. The energy density and power density of the COF materials were calculated based on Eq. (4) and Eq. (5):

$$
\begin{aligned}
& \text { Energy density }=C_{s p} \times V \\
& \text { Power Density }=C_{s p} \times V \times(C \text { rate })
\end{aligned}
$$


where $\mathrm{C}_{s p}$ is the specific capacity (Eq. 2), V is the average discharge potential versus a lithium metal anode, and C-rate is the C-rate at which the $\mathrm{C}_{\mathrm{sp}}$ was obtained. Energy density was calculated at $0.5 \mathrm{C}$ and power density was calculated at $20 \mathrm{C}$.

Electrochemical Impedance Spectroscopy. A BioLogic SP-150 potentiostat was used to carry out potentiostatic electrochemical impedance spectroscopy (PEIS) on assembled coin cells. Impedance measurements were obtained at the standard potential after the cell had been rested for at least 12 hours. The cell was first scanned at rate of $1 \mathrm{mV} / \mathrm{s}$ over a range of $1.4 \mathrm{~V}$ to $3.6 \mathrm{~V}$ vs. $\mathrm{Li} / \mathrm{Li}^{+}$, then scanned to its standard potential determined by the average potential of the anodic and cathodic peak of the first cycle. The cell was held at this potential for one hour before PEIS was performed to ensure steady state in the system. The measurements were taken over a frequency range of $0.001-1000000 \mathrm{~Hz}$ with an $\mathrm{AC}$ amplitude of $5.0 \mathrm{mV}$.

The cell response was plotted as a Nyquist plot. The EC Lab Z-fit software was used to fit the semicircle region at high and middle frequencies of the Nyquist plots using the following circuit:

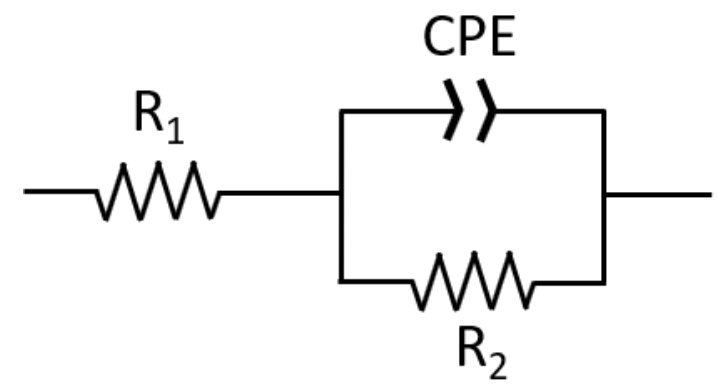

$\mathrm{R}_{1}$ corresponds to the solution resistance, $\mathrm{R}_{2}$ represents in charge transfer resistance, and CPE is the constant phase element accounting for the capacitance associated with the double layer formed between the electrode and the electrolyte. The obtained fit values are shown in Table S10.

The conductivity of the battery composites was calculated from the obtained PEIS data. Conductivity, $\sigma$, can be related to the charge transfer resistance by the following equation:

$$
\sigma=\frac{t}{R_{c t} \cdot A}
$$

Where $\mathrm{t}$ is the thickness of the electrode, measured by contact profilometry, and $\mathrm{A}$ is the area of the electrode $\left(1.267 \mathrm{~cm}^{2}\right)$. The conductivity is a measure of the conductivity of the entire composite (COF, super P, CMK-3, and PVDF). 
Galvanostatic Intermittent Titration Technique A Neware battery test station was used to perform galvanostatic intermittent titration technique (GITT) testing on assembled coin cells. Each cell was discharged and charged three times at $0.5 \mathrm{C}$. The cell was then subjected to eight minute current pulses of $0.5 \mathrm{C}$ followed by one hour of rest. This process was repeated until the equilibrium voltage reached $1.4 \mathrm{~V}$ during the discharge process and $3.6 \mathrm{~V}$ during the charge process. The diffusion coefficient of $\mathrm{Li}^{+}$was calculated using the following equation:

$$
D=\frac{4}{\pi \tau}\left(\frac{n_{m} V_{m}}{S}\right)^{2}\left(\frac{\Delta E_{s}}{\Delta E_{t}}\right)^{2}
$$

Where $\tau$ is the duration of the current pulse ( $480 \mathrm{~s}), \mathrm{n}_{\mathrm{m}}$ is the number of moles of COF, $\mathrm{V}_{\mathrm{m}}$ is the molar volume of the active material, $\mathrm{S}$ is the interfacial area $\left(0.713 \mathrm{~cm}^{2}\right), \Delta \mathrm{E}_{\mathrm{s}}$ is the steady-state voltage change determined from the difference in potential at the end of subsequent rest periods, and $\Delta \mathrm{E}_{\mathrm{t}}$ is the change in potential during the current pulse, eliminating the $\mathrm{iR}$ drop.

Post-mortem Analysis of DAPH-TFP COF To test the stability of DAPH-TFP COF during device testing, coin cells were disassembled and the cathode composite was removed for postmortem analysis. The cells were first cycled at $1 \mathrm{C}$ for the denoted number of cycles. After the cathode was removed, it was washed with dimethyl carbonate to wash away excess electrolyte and then blown dry. The composite was then analyzed using SEM, XRD, and XPS. XRD patterns were obtained at room temperature on a Rigaku Ultima IV powder diffractometer $\left(\mathrm{CuK}_{\alpha 1}\right.$ radiation, $\lambda$ $=1.54056 \AA$ ). The $\mathrm{Cu}$ X-ray tube was operated at $40 \mathrm{kV}$ and $44 \mathrm{~mA}$. The patterns were recorded in the $2 \theta$ range of $2-32^{\circ}$ and scanned at 2 degrees per a minute. Five scans were used to improve signal to noise for the composite sample. XPS analysis was done using a Surface Science Instruments SSX-100 ESCA Spectrometer using monochromatic Al Ka X-rays (1486.6 eV). Photoelectrons were collected from an analysis spot with a $800 \mu \mathrm{m}$ diameter at a $55^{\circ}$ emission angle with a source to analyzer angle of $54.7^{\circ}$. The operating pressure was $1 \times 10^{-9}$ Torr. The electron kinetic energy was determined with a hemispherical analyzer with a pass energy of 150 $\mathrm{eV}$ for the survey scan and $50 \mathrm{eV}$ with the high-resolution scans. SEM analysis was conducted as described in the Materials and Instrumentation section. 
Table S10. Fit values from PEIS at the standard potential of each COF material.

\begin{tabular}{l|c|c|c|c}
$\mathbf{C O F}$ & $\mathbf{R}_{\mathbf{1}}[\mathbf{\Omega}]$ & $\mathbf{C P E}\left[\mathbf{F} \bullet \mathbf{s}^{\mathbf{a}^{\wedge}-1}\right]$ & $\mathbf{a}$ & $\mathbf{R}_{\mathbf{2}}[\mathbf{\Omega}]$ \\
\hline DAAQ-TFP & 3.491 & $6.794 \times 10^{-6}$ & 0.868 & 188.3 \\
\hline DAPH-TFP & 3.567 & $5.185 \times 10^{-6}$ & 0.885 & 163.7 \\
\hline PEDOT@DAAQ-TFP & 3.129 & $10.88 \times 10^{-6}$ & 0.839 & 94.82 \\
\hline PEDOT@DAPH-TFP & 3.231 & $7.277 \times 10^{-6}$ & 0.869 & 130.5
\end{tabular}

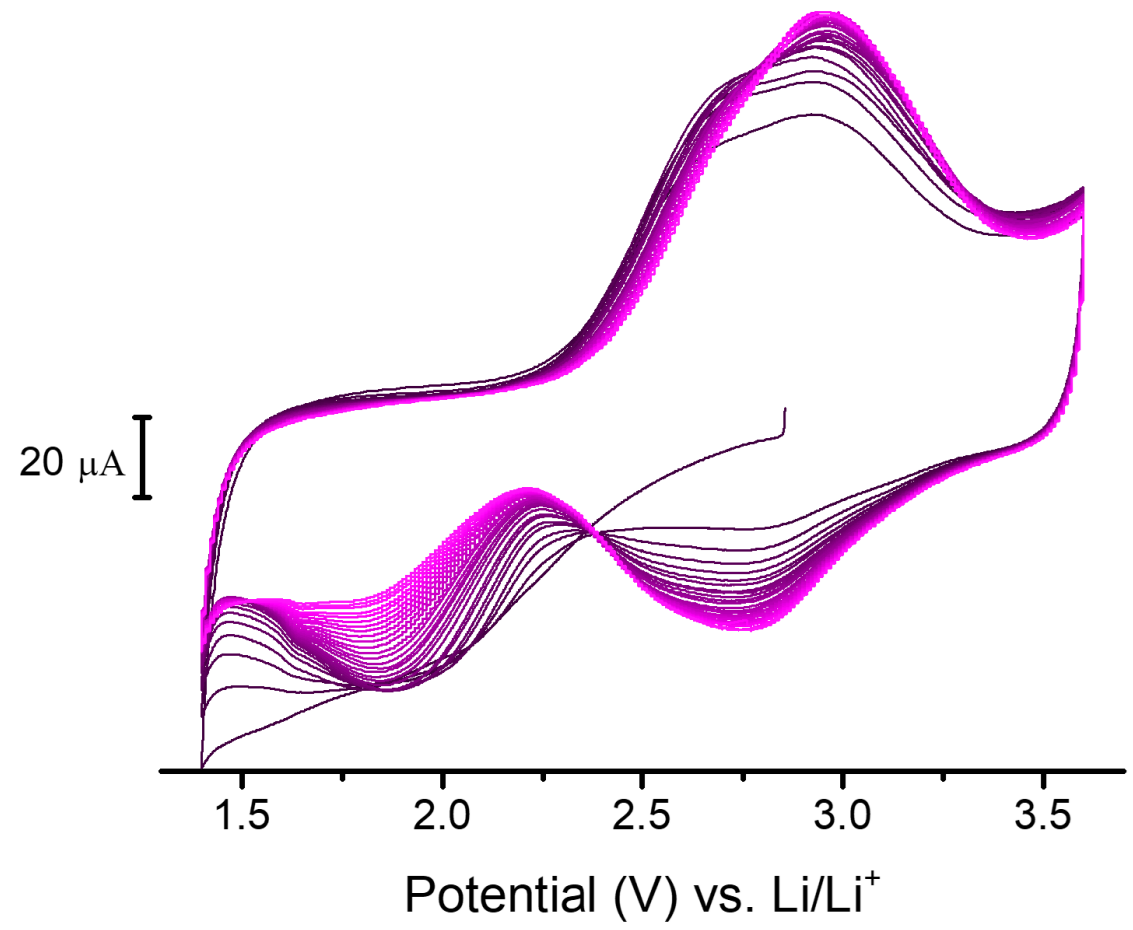

Figure S36. CV profiles of 20 cycles on PEDOT@DAPH-TFP COF at $2 \mathrm{mV} / \mathrm{s}$ as an assembled coin cell. Color goes from dark to light purple with subsequent cycles. The same trend was observed in DAPH-TFP coin cells, but not in the DAAQ-TFP-based materials. This observation is likely due to some form of activation process occurring during the initial cycling of the DAPHTFP COF material. The initial cycles of the COF material likely require some additional activation energy associated with the movement of ions through the structure. The DAPH-TFP COF during these initial cycles undergoes a conversion process as indicated by the isopotential points in the $\mathrm{CV}$ traces (at $2.4 \mathrm{~V}$ during reduction and $2.8 \mathrm{~V}$ during oxidation). After this conversion, the insertion of ions requires a smaller overpotential, as observed by the shift of the reduction peak to a higher potential. 


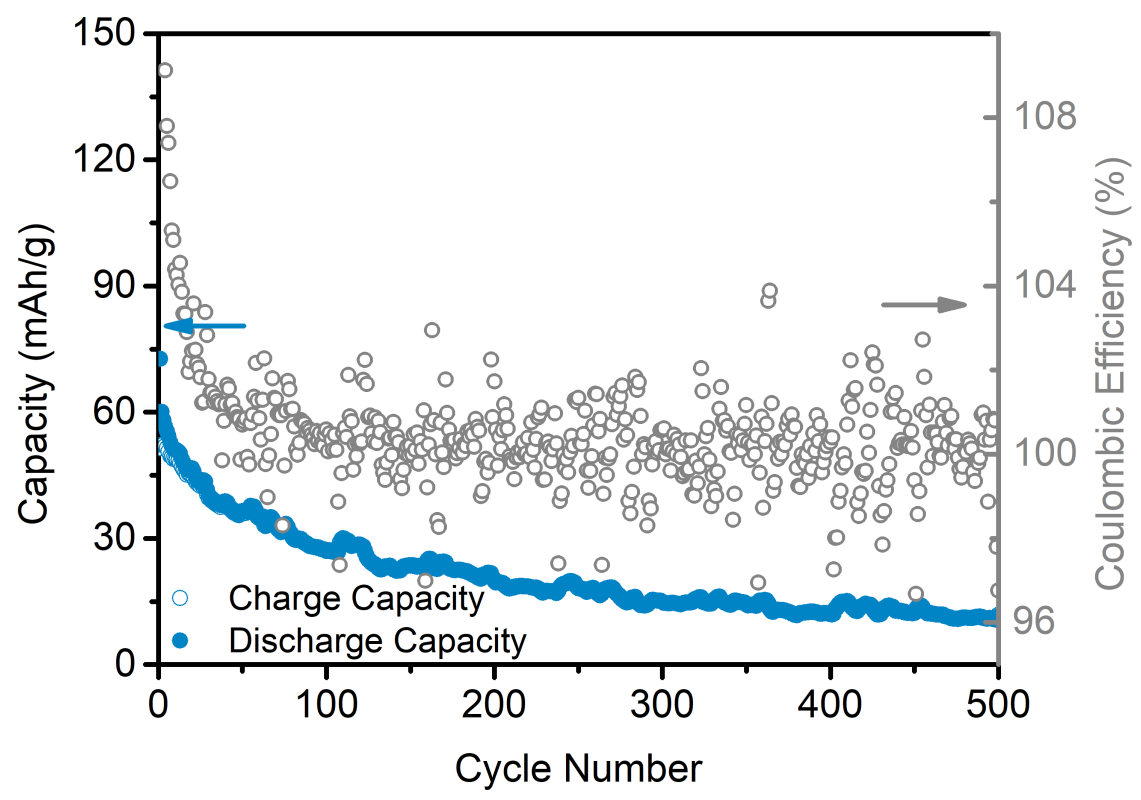

Figure S37. Representative DAAQ-TFP COF coin cell showing coulombic efficiency with cycling at a charge/discharge rate of $1 \mathrm{C}$.

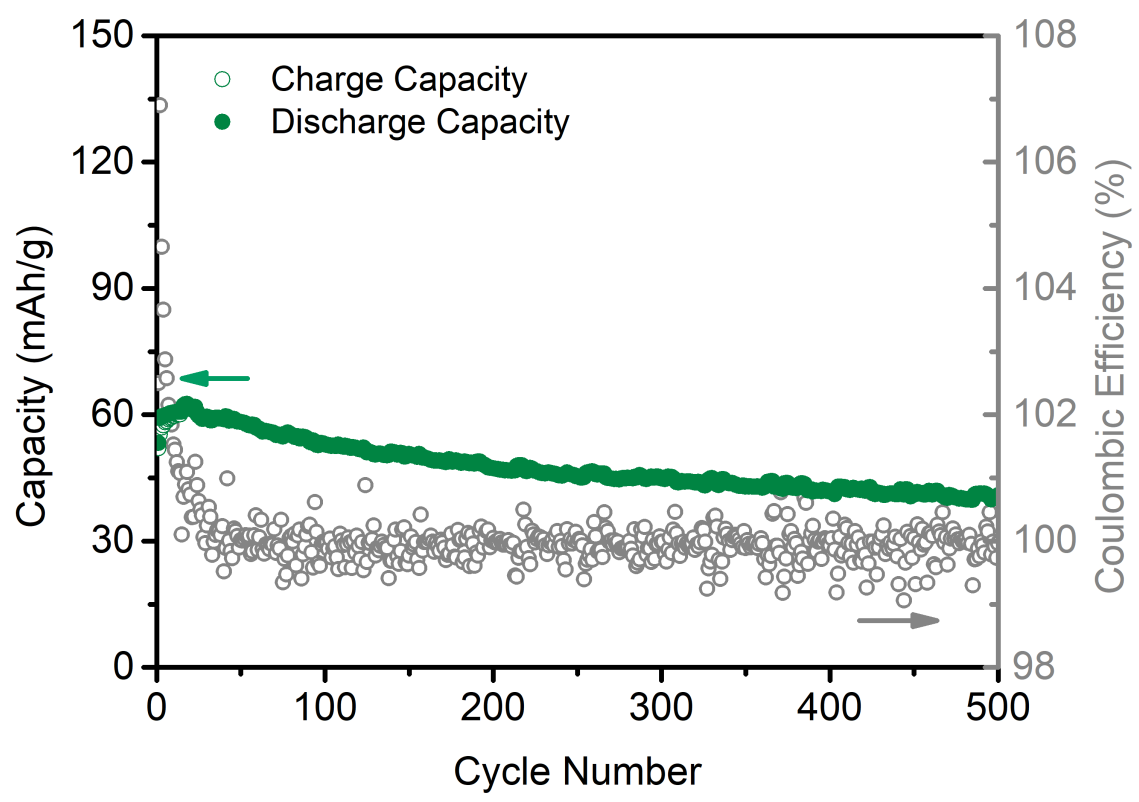

Figure S38. Representative DAPH-TFP COF coin cell showing coulombic efficiency with cycling at a charge/discharge rate of $1 \mathrm{C}$. 


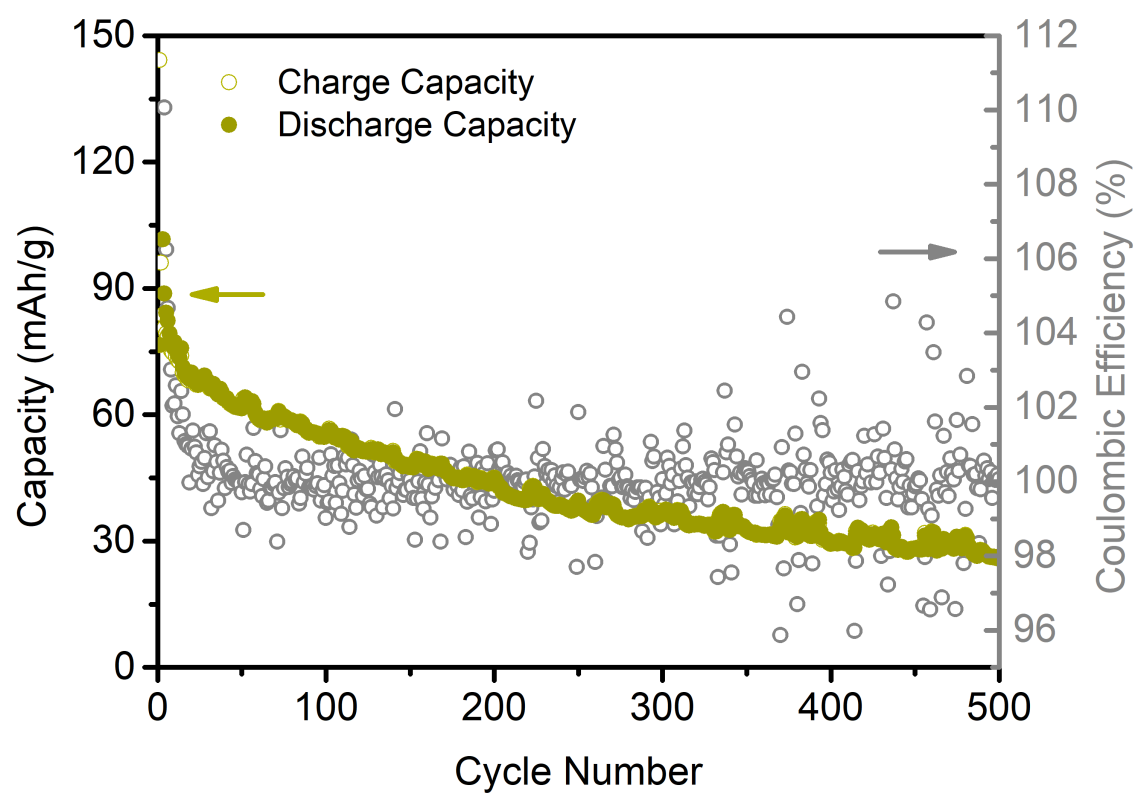

Figure S39. Representative PEDOT@DAAQ-TFP COF coin cell showing coulombic efficiency with cycling at a charge/discharge rate of $1 \mathrm{C}$.

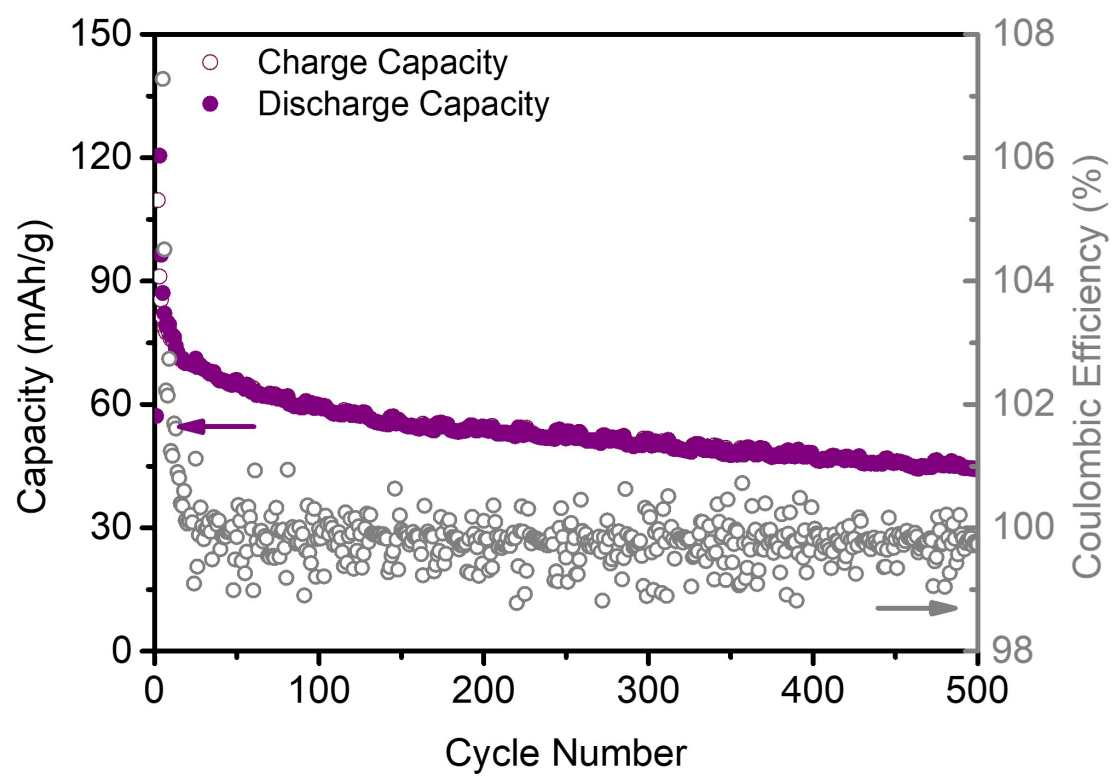

Figure S40. Representative PEDOT@DAPH-TFP COF coin cell showing coulombic efficiency with cycling at a charge/discharge rate of $1 \mathrm{C}$. 


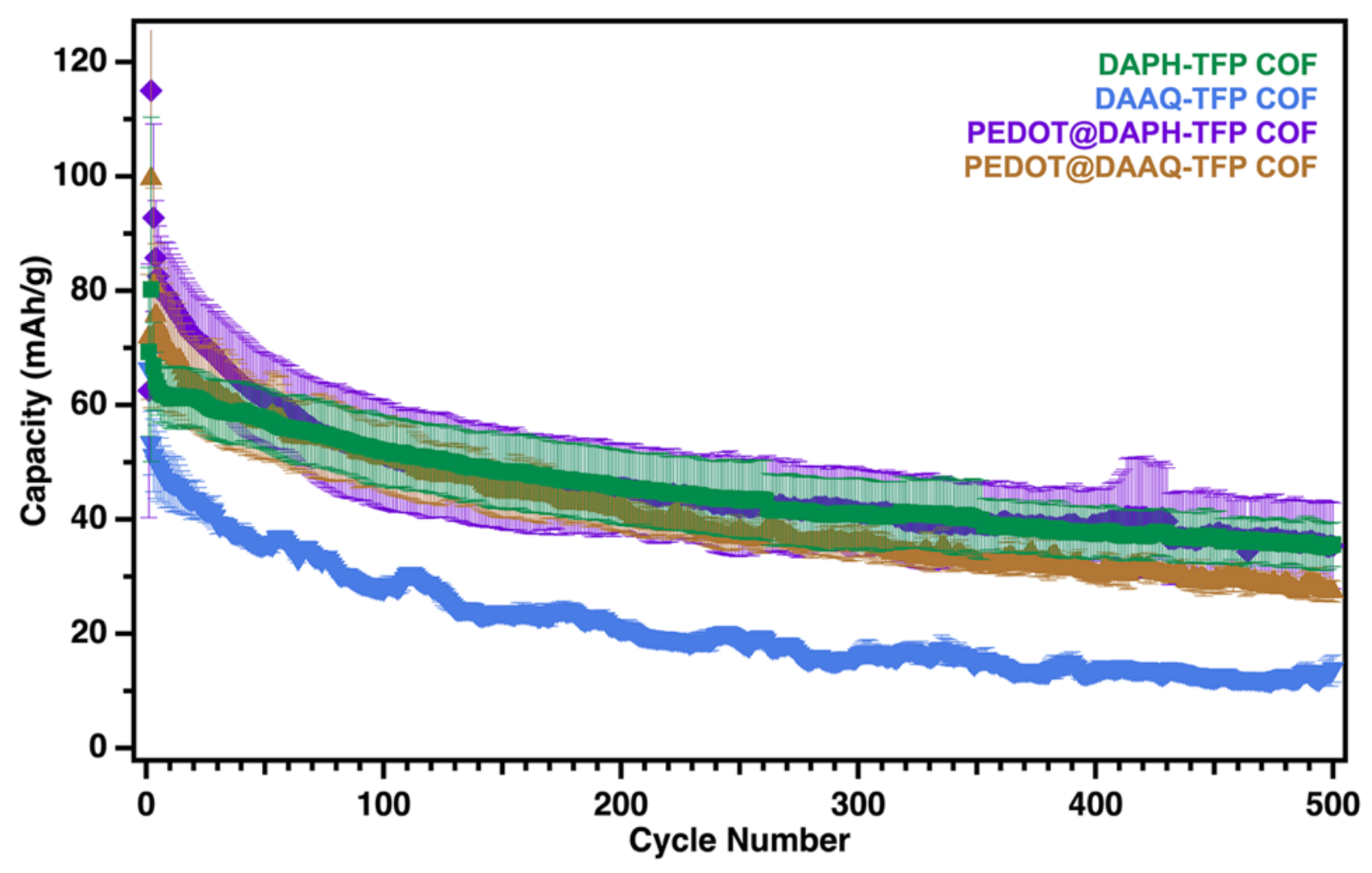

Figure S41. Discharge capacity (same as Figure 3C) at $1 \mathrm{C}$ of all four materials over 500 cycles, with the associated standard deviation from three different cells. 

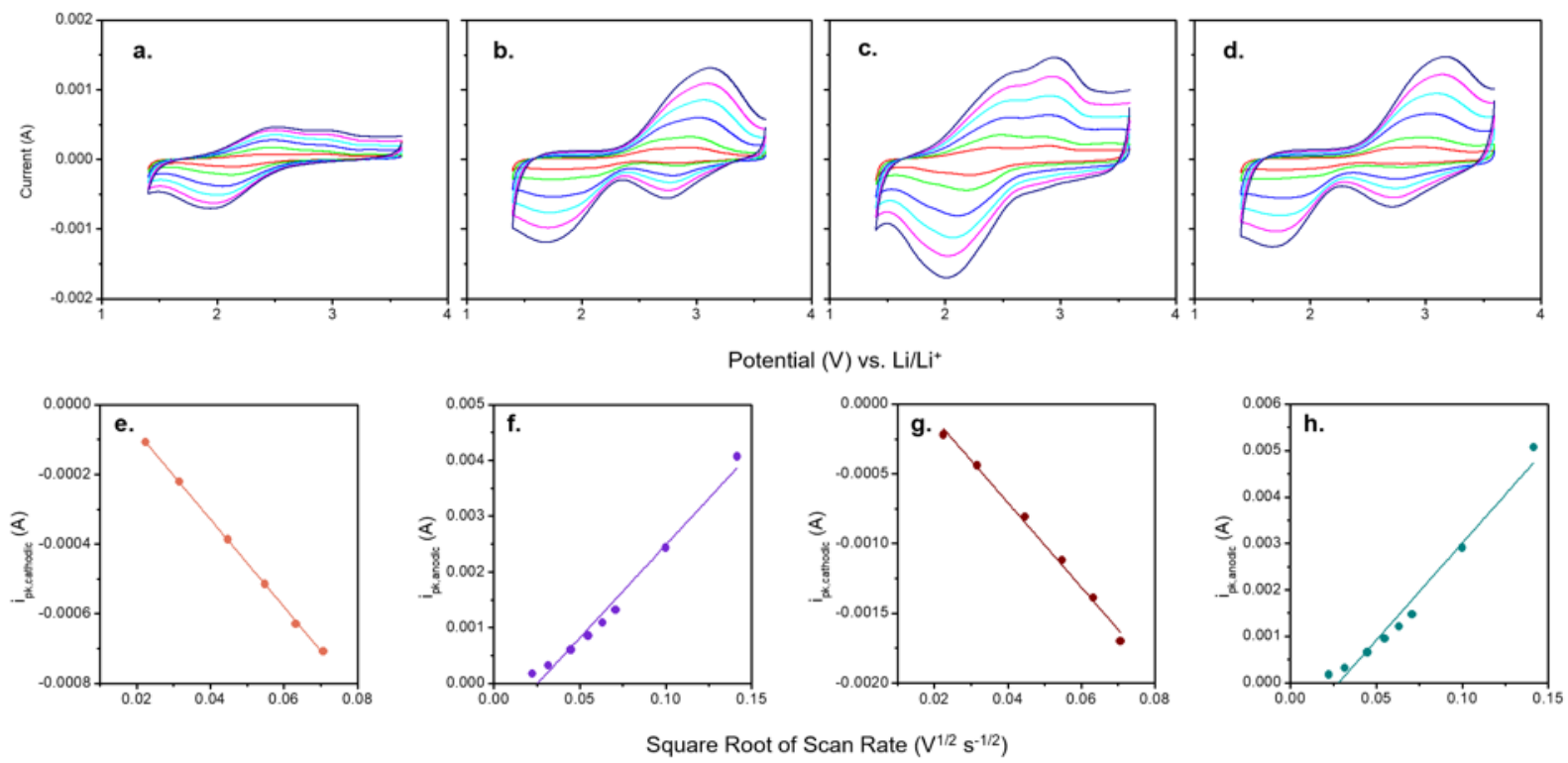

Figure S42. (a, b, c, d) CV profiles at $0.5,1,2,3,4$, and $5 \mathrm{mV} / \mathrm{s}$ and corresponding linear fits of the peak current vs. square root of scan rate $(e, f, g, h)$ of four COF materials: (a, e) DAAQ-TFP COF, (b, f) DAPH-TFP COF, (c, g) PEDOT@DAAQ-TFP COF, and (d, h) PEDOT@DAPH-TFP COF. The obtained slopes from the fits was used to calculate the diffusion coefficient of $\mathrm{Li}^{+}$ion in each of the COF materials according to the Eq. 3. For the DAAQ-TFP COF materials, the reduction peak was used for analysis, due to the overlap of two oxidation peaks which grow at different rates with cycling. For the DAPH-TFP COF materials, the oxidation peak was used for analysis to minimize inaccuracies associated with attempting to quantify peaks associated with the conversion type reaction occurring with cycling.

Table S11. Linear fits and $\mathrm{R}^{2}$ values obtained from the Randles-Sevcik plots.

\begin{tabular}{l|c|c|c}
$\mathbf{C O F}$ & Slope $\left(\mathbf{A} \cdot \mathbf{s}^{\mathbf{1 / 2}} \cdot \mathbf{V}^{\mathbf{- 1 / 2}}\right)$ & $\mathbf{y}$-int $\mathbf{( A )}$ & $\mathbf{R}^{\mathbf{2}}$ \\
\hline DAAQ-TFP & -0.0126 & 0.0002 & 0.999 \\
\hline DAPH-TFP & 0.0333 & 0.0008 & 0.982 \\
\hline PEDOT@DAAQ-TFP & -0.0303 & 0.0005 & 0.994 \\
\hline PEDOT@DAPH-TFP & 0.0418 & 0.0012 & 0.973
\end{tabular}



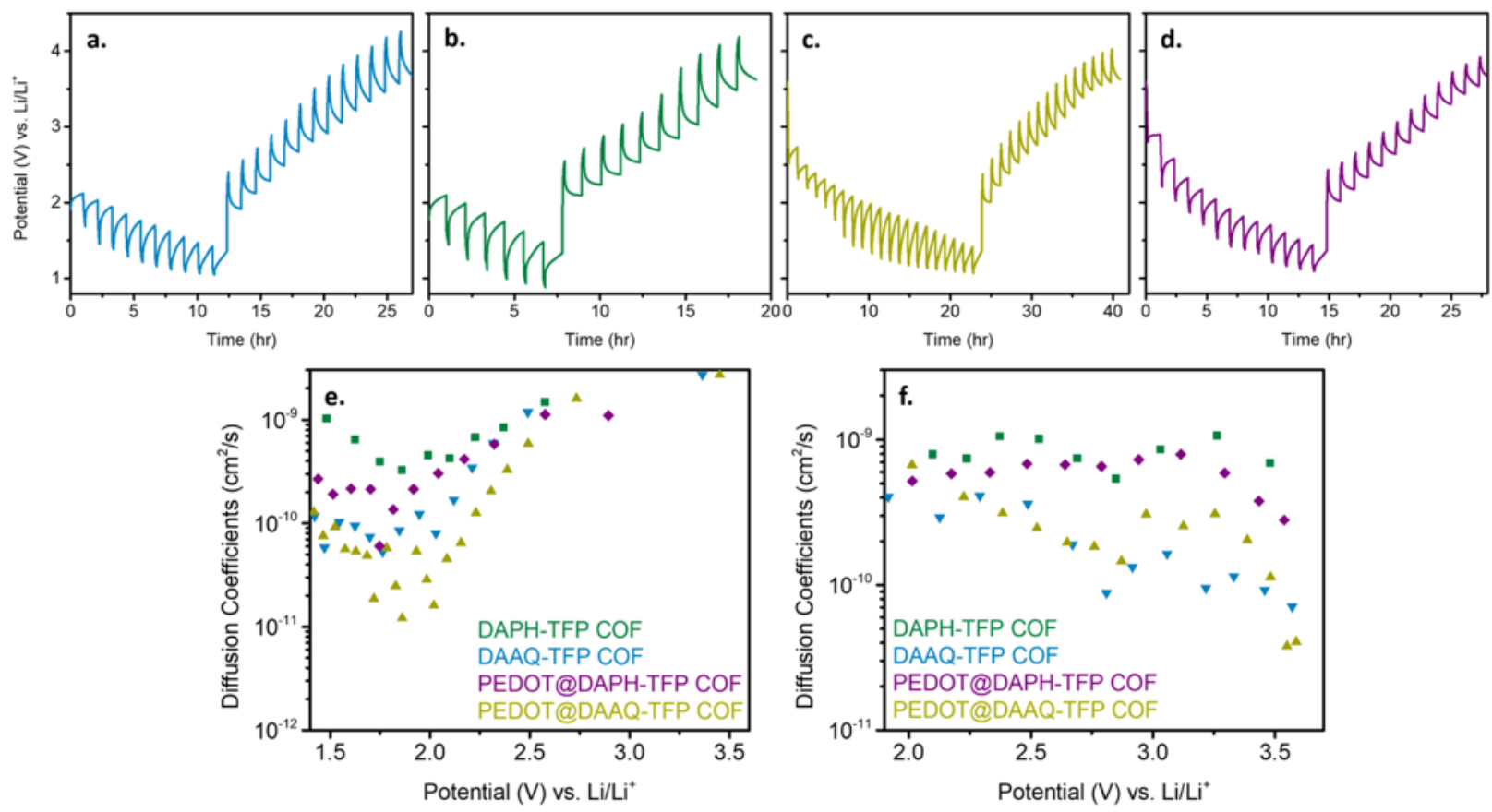

Figure S43. GITT curves of (a) DAAQ-TFP COF, (b) DAPH-TFP COF, (c) PEDOT@DAAQTFP COF, and (d) DAPH-TFP COF. Calculated $\mathrm{Li}^{+}$diffusion coefficients as a function of potential vs. $\mathrm{Li} / \mathrm{Li}^{+}$during (e) charge and (f) discharge.

Table S12. Select diffusion coefficients obtained from GITT.

\begin{tabular}{c|c|c} 
COF & $\begin{array}{c}\mathbf{2 . 0 ~ V ~ v s . ~} \mathbf{~ L i} / \mathbf{L i}^{+} \\
(\text {discharge })\left[\mathbf{c m}^{2} / \mathbf{s}\right]\end{array}$ & $\begin{array}{c}\mathbf{2 . 5} \mathbf{~ V ~ v s . ~} \mathbf{~ L i} / \mathbf{L i}^{+} \\
(\mathbf{c h a r g e})\left[\mathbf{c m}^{2} / \mathbf{s}\right]\end{array}$ \\
\hline DAAQ-TFP & $7.95 \times 10^{-11}$ & $3.61 \times 10^{-10}$ \\
\hline DAPH-TFP & $4.55 \times 10^{-10}$ & $1.02 \times 10^{-9}$ \\
\hline PEDOT@DAAQ-TFP & $1.61 \times 10^{-11}$ & $2.46 \times 10^{-10}$ \\
\hline PEDOT@DAPH-TFP & $3.04 \times 10^{-10}$ & $6.82 \times 10^{-10}$
\end{tabular}




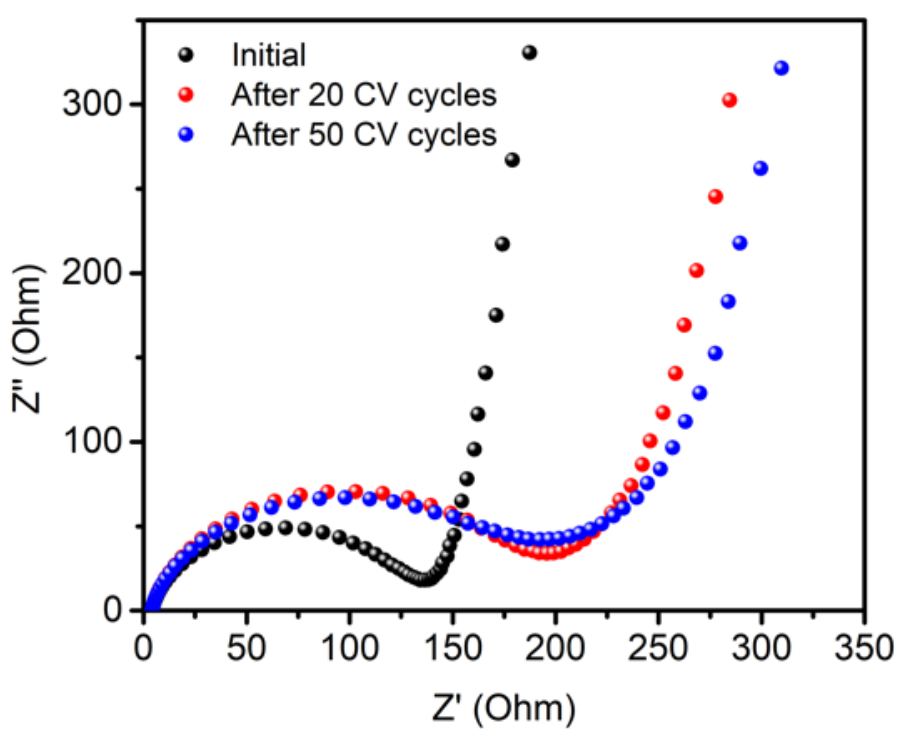

Figure S44. PEIS response of DAPH half cell $\left(\mathrm{A}=0.713 \mathrm{~cm}^{2}\right)$ acquired at the redox couple's standard potential before cycling (black), and after 20 (red) and 50 (blue) CV cycles between 1.4 and $3.6 \mathrm{~V}$ vs. $\mathrm{Li} / \mathrm{Li}^{+}$at $1 \mathrm{mV} / \mathrm{s}$. $\mathrm{R}_{\mathrm{ct}}$ increases after initial cycling, likely due to formation of electrode electrolyte interfaces, but remains stable with further cycling. 


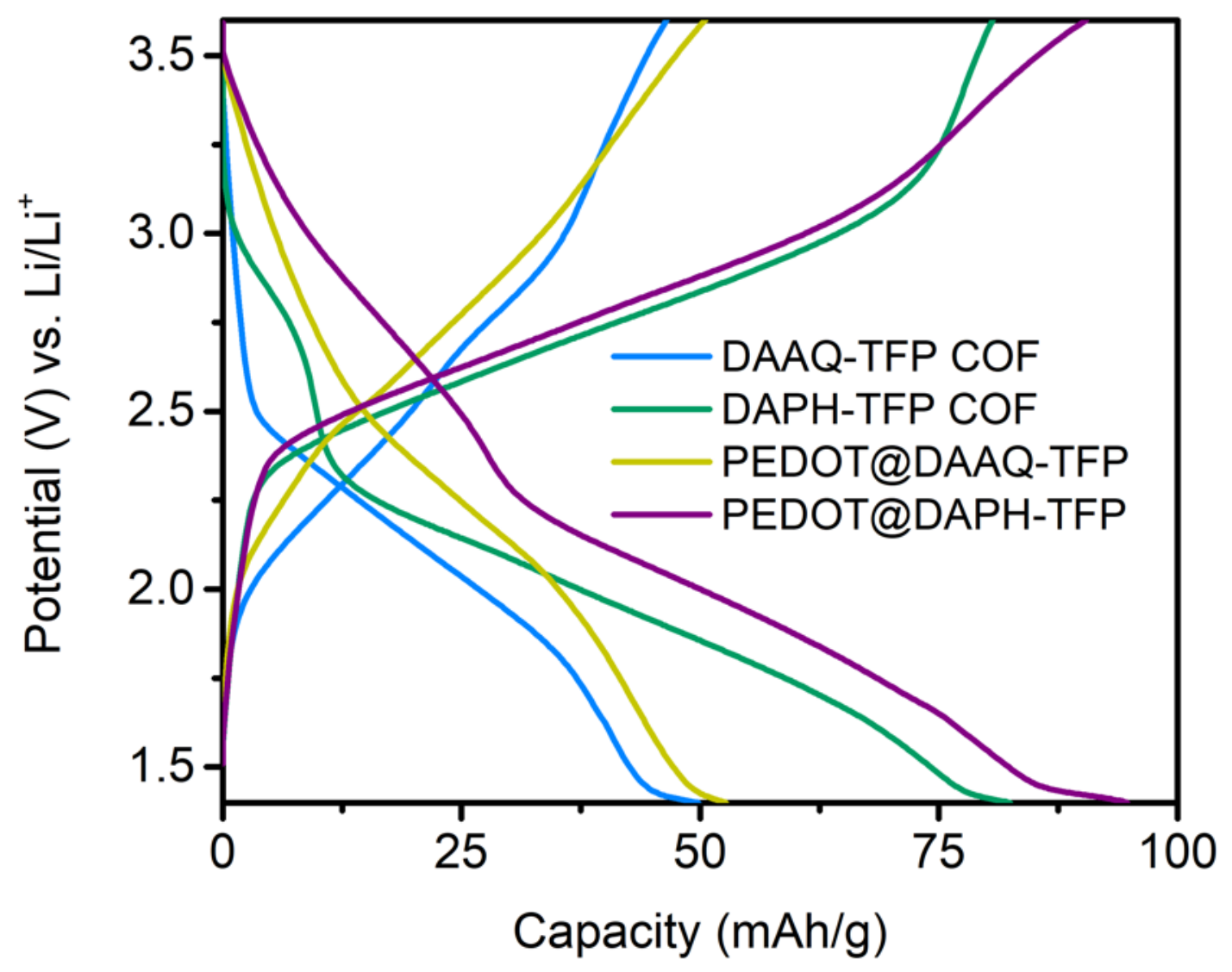

Figure S45. Charge/discharge curves of COF samples at $0.5 \mathrm{C}$. 


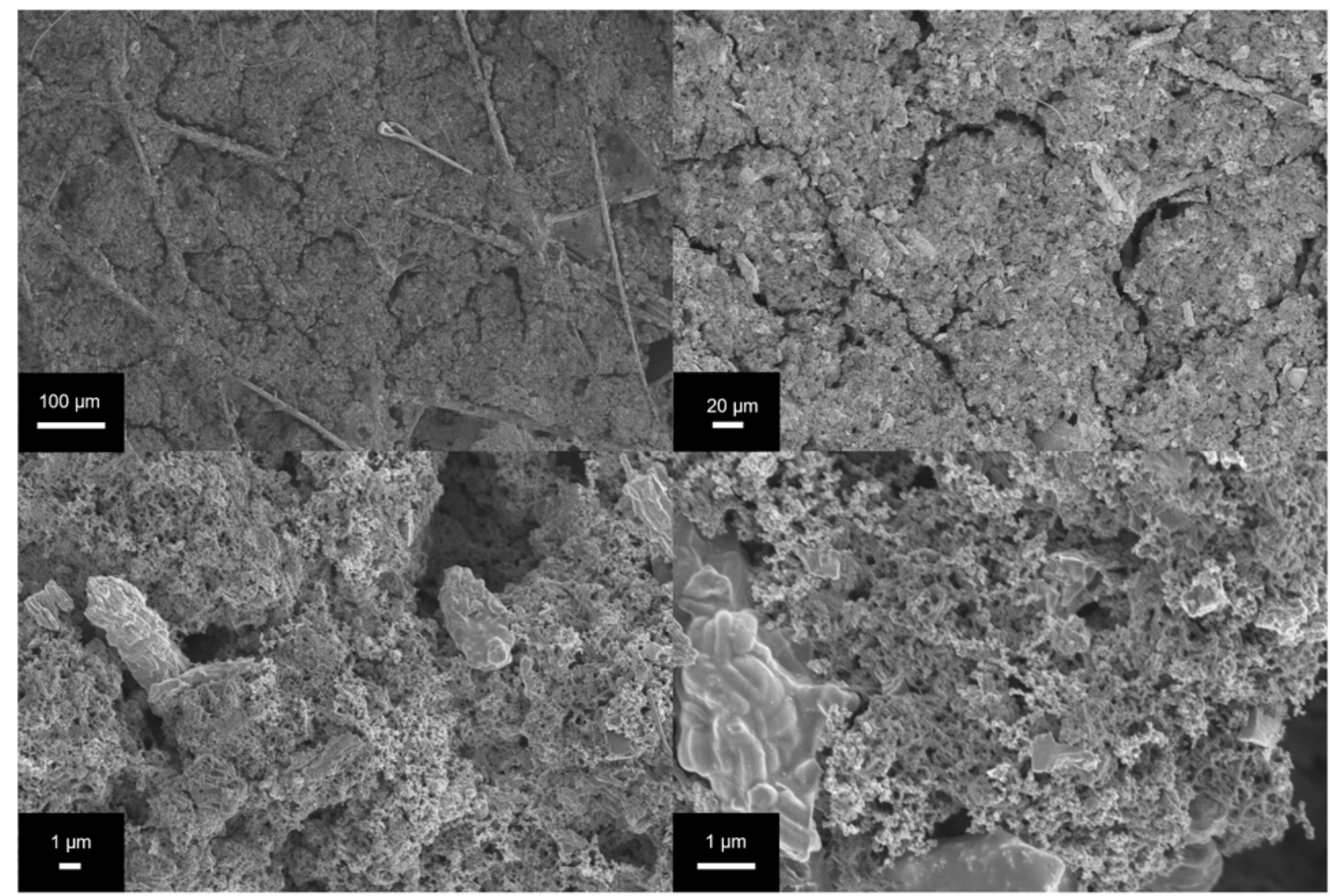

Figure S46. SEM images of the DAPH-TFP COF composite cathode after 100 cycles at $1 \mathrm{C}$. The porosity observed in the pristine cathode composite is still observed in the higher magnification images, indicating the morphology of the material remains unchanged with cycling the battery. Some additionally cracking observed in the composite which may be a product of the disassembly/washing process necessary to prepare the sample for post-mortem SEM analysis. 


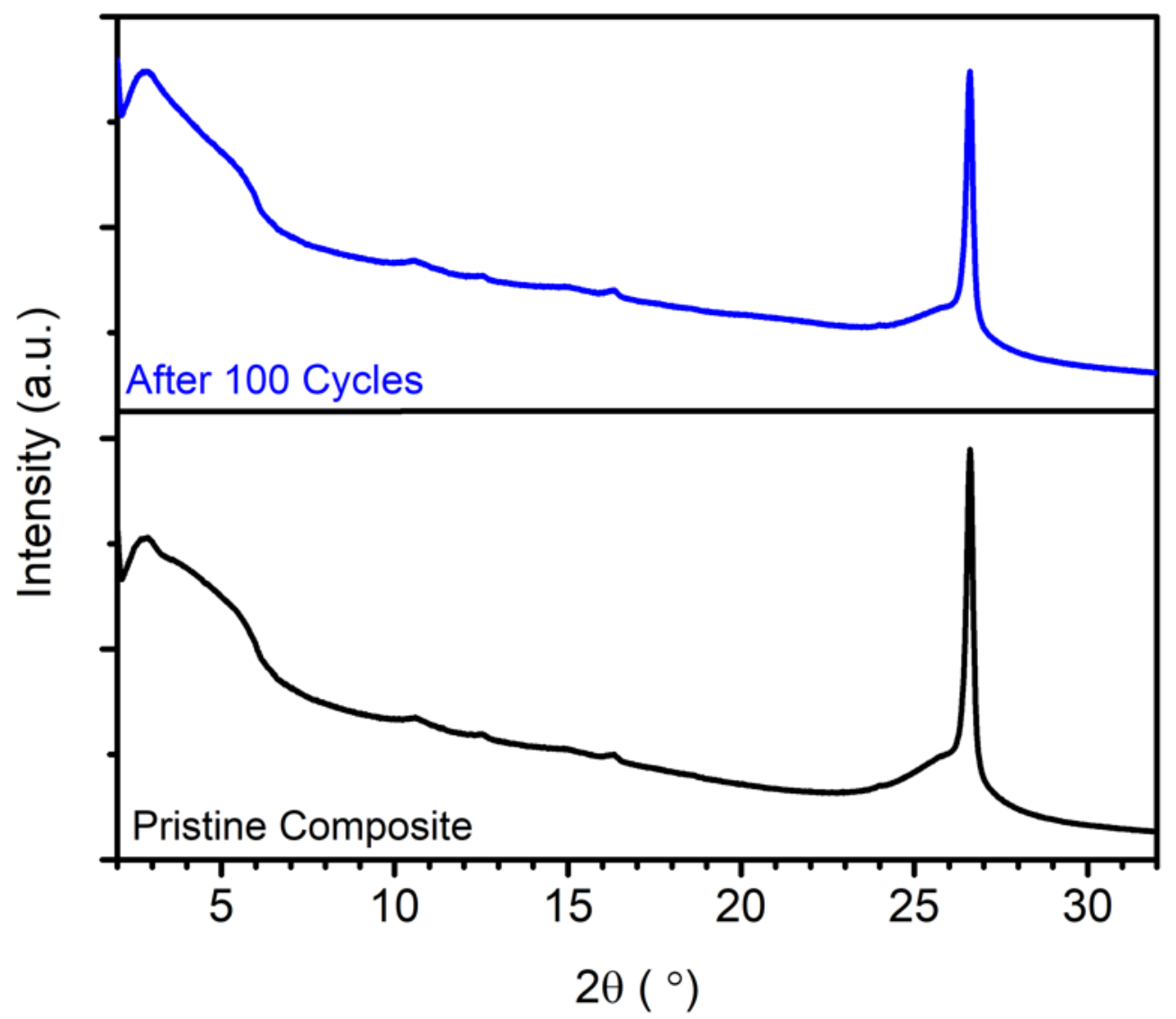

Figure S47. Powder XRD spectra of the DAPH-TFP cathode composite in the pristine state (before cycling or exposure to the electrolyte solution) and after 100 cycles at $100 \mathrm{C}$. Diminished crystallinity is observed in the composite compare to the bare COF powder due to the incorporation of carbon and binder on a carbon paper current collector. We observe broadened peaks at low angles in the composite as well as a large peak at $\sim 25^{\circ}$ due to the CMK-3 used as a conductive additive in the composite. The two powder XRDs before and after cycling remain the same, leading us to believe the material is stable during cycling. 

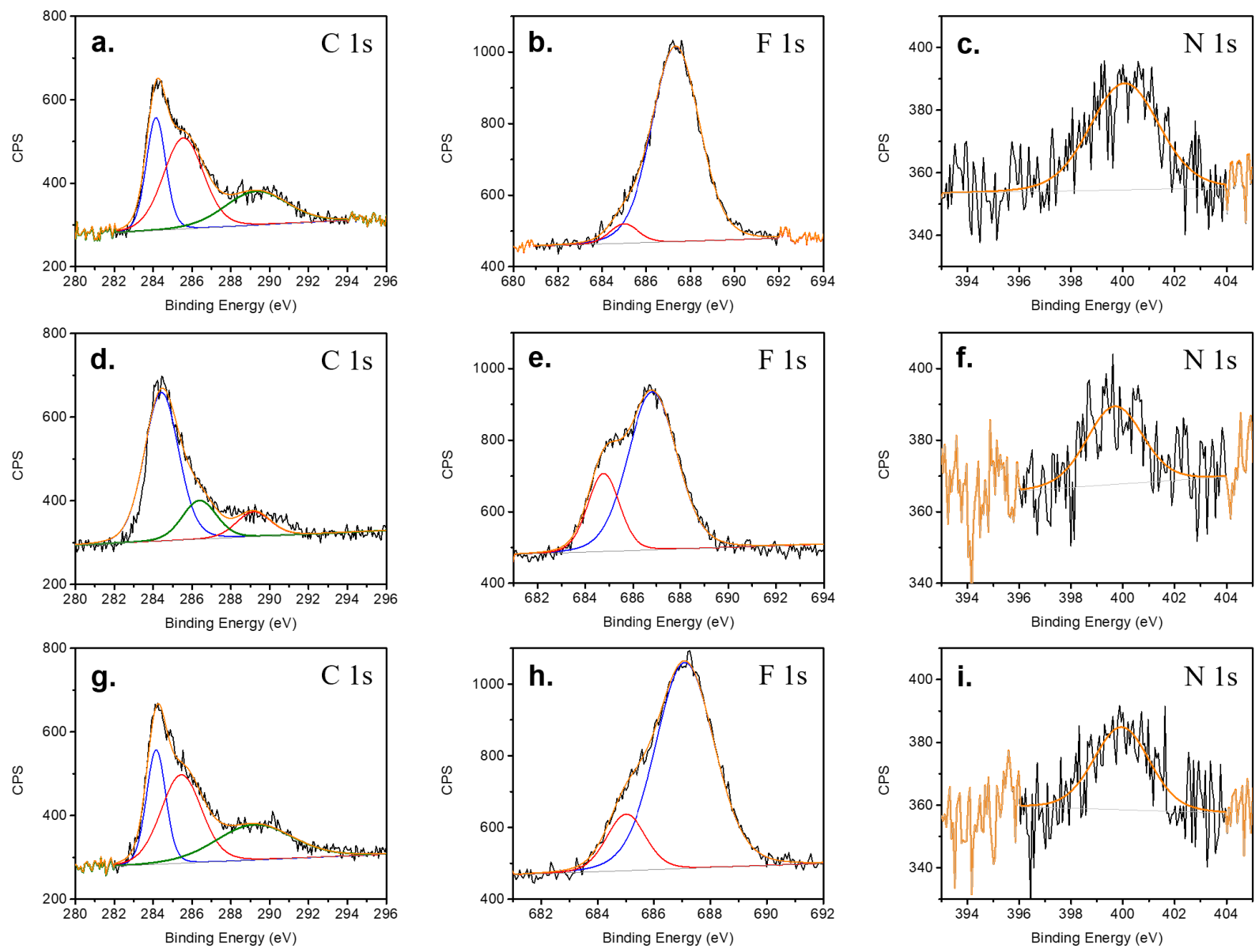

Figure S48. High resolution spectra from XPS for DAPH-TFP COF cathode composites after assembly (a, b, c), 25 cycles (d, e, f), and 100 cycles (g, h, i). The C 1s spectra (a, d, g) remains largely unchanged with cycling, indicating the carbon in the COF and the composite retain their chemical environment. The F 1s spectra (b, e, h) develop a shoulder at higher binding energies with cycling, a likely consequence of SEI formation on the surface of the cathode. The N 1s spectra (c, f, i) also appear very similar with cycling, although it is difficult to distinguish much information due to the noise in the spectra. 
Table S13. Performance metrics of representative covalent organic frameworks as cathode materials for lithium ion batteries.

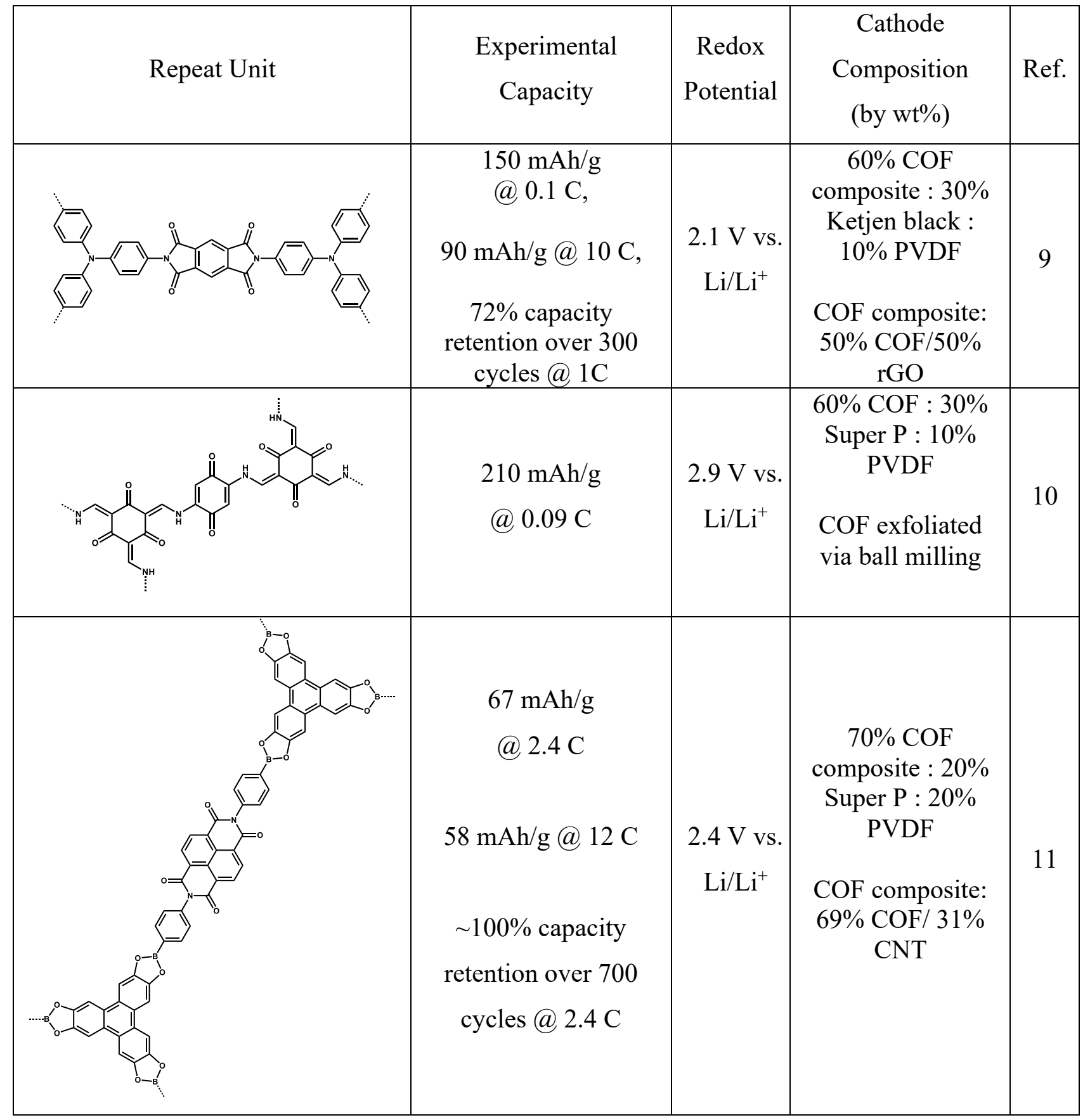




\begin{tabular}{|c|c|c|c|c|}
\hline & $\begin{array}{c}135.4 \mathrm{mAh} / \mathrm{g} \\
@ 0.34 \mathrm{C} \\
66.6 \mathrm{mAh} / \mathrm{g} @ 13.7 \mathrm{C} \\
65 \% \text { capacity } \\
\text { retention over } 300 \\
\text { cycles@ } 1.4 \mathrm{C}\end{array}$ & $\begin{array}{c}2.3 \mathrm{~V} \text { vs. } \\
\mathrm{Li} / \mathrm{Li}^{+}\end{array}$ & $\begin{array}{c}60 \% \text { COF : } 20 \% \\
\text { Super P : } 20 \% \\
\text { PVDF }\end{array}$ & 12 \\
\hline & $\begin{array}{c}271 \mathrm{mAh} / \mathrm{g} \\
@ 0.1 \mathrm{C} \\
195 \mathrm{mAh} / \mathrm{g} @ 10 \mathrm{C} \\
86 \% \text { capacity } \\
\text { retention over } 300 \\
\text { cycles@1 C }\end{array}$ & $\begin{array}{c}2.3 \mathrm{~V} \text { vs. } \\
\mathrm{Li} / \mathrm{Li}^{+}\end{array}$ & $\begin{array}{c}80 \% \text { COF } \\
\text { composite : } 10 \% \\
\text { Ketjen black : } \\
10 \% \text { PVDF } \\
\text { COF composite: } \\
80 \% \text { COF/ } 20 \% \\
\text { graphene }\end{array}$ & 13 \\
\hline & $\begin{array}{c}104.4 \mathrm{mAh} / \mathrm{g} \\
@ 0.8 \mathrm{C} \\
95 \text { mAh/g@10 C } \\
\sim 100 \% \text { capacity } \\
\text { retention over } 8000 \\
\text { cycles@ } 4 \mathrm{C}\end{array}$ & $\begin{array}{c}2.4 \mathrm{~V} \text { vs. } \\
\mathrm{Li} / \mathrm{Li}^{+}\end{array}$ & $\begin{array}{c}80 \% \text { COF } \\
\text { composite : } 10 \% \\
\text { super P : } 10 \% \\
\text { Alginate sodium } \\
\\
\text { COF composite: } \\
50 \% \text { COF } / 50 \% \\
\text { CNT }\end{array}$ & 14 \\
\hline $\mathrm{Li}\left(\mathrm{Ni}_{8} \mathrm{Mn}_{1} \mathrm{Co}_{1}\right) \mathrm{O}_{2}$ & >185 mAh/g@0.1 C & $\begin{array}{c}\sim 3.9 \mathrm{~V} \\
\text { vs. } \mathrm{Li} / \mathrm{Li}^{+}\end{array}$ & $\begin{array}{l}90 \% \text { LNMC : } 5 \% \\
\text { conductive carbon } \\
: 5 \% \text { binder }\end{array}$ & 15 \\
\hline
\end{tabular}


Table S14. Cell parameters of Li ||$C O F$ coin cells. Calculations of energy density normalized to the mass of all the components present in the half cells tested here. Although device testing in this work is done at material-level exploration, and thus excess lithium and electrolyte solution has been employed along with low areal loadings, these calculations are intended to provide a method to better compare with other developed materials. ${ }^{16}$

\begin{tabular}{|c|c|c|}
\hline Cell Component & Cell Parameters & \\
\hline \multirow[t]{12}{*}{ DAPH-TFP COF Cathode } & $\begin{array}{l}1 \text { st Discharge Capacity (mAh/g } \\
\text { active material) }\end{array}$ & 96.2 \\
\hline & $\begin{array}{l}\text { Discharge Capacity at } 20 \mathrm{C} \\
(\mathrm{mAh} / \mathrm{g} \text { active material })\end{array}$ & 49.3 \\
\hline & active material loading & 0.6 \\
\hline & total coating weight $\left(\mathrm{mg} / \mathrm{cm}^{2}\right)$ & 1.33 \\
\hline & areal capacity $\left(\mathrm{mAh} / \mathrm{cm}^{2}\right)$ & 0.128 \\
\hline & electrode area $\left(\mathrm{cm}^{2}\right)$ & 0.713 \\
\hline & $\begin{array}{l}\text { active material mass }(\mathrm{g}) \\
\text { electrode thickness }(\mathrm{C} \text { current } \\
\text { collector }+ \text { active material }) \\
(\mu \mathrm{m})\end{array}$ & 0.00057 \\
\hline & current collector mass (g) & 0.0025 \\
\hline & electrode density $\left(\mathrm{g} / \mathrm{cm}^{3}\right)$ & 0.484 \\
\hline & $\begin{array}{l}\text { energy density (Wh/Kg of } \\
\text { COF) }\end{array}$ & 221.26 \\
\hline & $\begin{array}{l}\text { energy density }(\mathrm{Wh} / \mathrm{Kg} \\
\text { composite }(\mathrm{COF}+\text { carbon }+ \\
\text { binder) }\end{array}$ & 132.76 \\
\hline & $\begin{array}{l}\text { power density }(\mathrm{W} / \mathrm{Kg} \text { of } \mathrm{COF}) \\
\text { energy density }(\mathrm{W} / \mathrm{Kg} \\
\text { composite }(\mathrm{COF}+\text { carbon }+ \\
\text { binder) }\end{array}$ & 1360.68 \\
\hline \multirow[t]{4}{*}{ Li anode } & electrode thickness $(\mathrm{cm})$ & 0.075 \\
\hline & electrode radius $\left(\mathrm{cm}^{2}\right)$ & 0.714 \\
\hline & mass of lithium anode (g) & 0.064 \\
\hline & cell balance (N/P ratio) & 4528.2 \\
\hline \multirow[t]{4}{*}{ Electrolyte } & electrolyte volume $\left(\mathrm{cm}^{3}\right)$ & 0.08 \\
\hline & electrolyte density $\left(\mathrm{g} / \mathrm{cm}^{3}\right)$ & 1.26 \\
\hline & electrolyte mass (g) & 0.1008 \\
\hline & electrolyte/capacity (g/Ah) & 1841.6 \\
\hline Separator & mass $(\mathrm{g})$ & 0.0143 \\
\hline Packaging foil & $\begin{array}{l}\text { mass of coin cell components } \\
\text { (g) }\end{array}$ & 2.7218 \\
\hline
\end{tabular}




\begin{tabular}{|l|r|r|}
\hline Cell & weight of coin cell $(\mathrm{g})$ & 2.904 \\
\hline & voltage $(\mathrm{V})$ & 2.3 \\
\hline capacity $(\mathrm{Ah})$ & $5.47 \times 10^{-5}$ \\
\hline energy density $(\mathrm{Wh} / \mathrm{Kg})$ & $4.33 \times 10^{-2}$ \\
\hline
\end{tabular}

\begin{tabular}{|c|c|c|}
\hline Cell Component & Cell Parameters & \\
\hline \multirow[t]{14}{*}{$\begin{array}{l}\text { DAAQ-TFP COF } \\
\text { Cathode }\end{array}$} & $\begin{array}{l}\text { 1st Discharge Capacity (mAh/g } \\
\text { active material) }\end{array}$ & 73.2 \\
\hline & $\begin{array}{l}\text { Discharge Capacity at } 20 \mathrm{C} \\
\text { (mAh/g active material) }\end{array}$ & 16.9 \\
\hline & active material loading & 0.6 \\
\hline & total coating weight $\left(\mathrm{mg} / \mathrm{cm}^{2}\right)$ & 1.33 \\
\hline & areal capacity $\left(\mathrm{mAh} / \mathrm{cm}^{2}\right)$ & 0.097 \\
\hline & electrode area $\left(\mathrm{cm}^{2}\right)$ & 0.713 \\
\hline & active material mass (g) & 0.00057 \\
\hline & $\begin{array}{l}\text { electrode thickness }(\mathrm{C} \text { current } \\
\text { collector }+ \text { active material }) \\
(\mu \mathrm{m})\end{array}$ & 100 \\
\hline & current collector mass $(\mathrm{g})$ & 0.0025 \\
\hline & electrode density $\left(\mathrm{g} / \mathrm{cm}^{3}\right)$ & 0.484 \\
\hline & $\begin{array}{l}\text { energy density }(\mathrm{Wh} / \mathrm{Kg} \text { of } \\
\mathrm{COF})\end{array}$ & 161.04 \\
\hline & $\begin{array}{l}\text { energy density }(\mathrm{Wh} / \mathrm{Kg} \\
\text { composite }(\mathrm{COF}+\text { carbon }+ \\
\text { binder })\end{array}$ & 96.62 \\
\hline & power density (W/Kg of COF) & 743.6 \\
\hline & $\begin{array}{l}\text { energy density }(\mathrm{W} / \mathrm{Kg} \\
\text { composite }(\mathrm{COF}+\text { carbon }+ \\
\text { binder) }\end{array}$ & 446.16 \\
\hline \multirow[t]{4}{*}{ Li anode } & electrode thickness $(\mathrm{cm})$ & 0.075 \\
\hline & electrode radius $\left(\mathrm{cm}^{2}\right)$ & 0.714 \\
\hline & mass of lithium anode $(\mathrm{g})$ & 0.064 \\
\hline & cell balance (N/P ratio) & 5951.0 \\
\hline \multirow[t]{4}{*}{ Electrolyte } & electrolyte volume $\left(\mathrm{cm}^{3}\right)$ & 0.08 \\
\hline & electrolyte density $\left(\mathrm{g} / \mathrm{cm}^{3}\right)$ & 1.26 \\
\hline & electrolyte mass (g) & 0.1008 \\
\hline & electrolyte/capacity (g/Ah) & 2420.2 \\
\hline Separator & $\operatorname{mass}(\mathrm{g})$ & 0.0143 \\
\hline Packaging foil & $\begin{array}{l}\text { mass of coin cell components } \\
(\mathrm{g})\end{array}$ & 2.7218 \\
\hline Cell & weight of coin cell $(\mathrm{g})$ & 2.904 \\
\hline
\end{tabular}




\section{Cell Component \\ PEDOT@DAPH-TFP \\ COF Cathode}

\section{Cell Parameters}

1st Discharge Capacity (mAh/g active material)

99.2

Discharge Capacity at $20 \mathrm{C}$ (mAh/g active material)

active material loading

0.522

total coating weight $\left(\mathrm{mg} / \mathrm{cm}^{2}\right)$

areal capacity $\left(\mathrm{mAh} / \mathrm{cm}^{2}\right)$

0.132

electrode area $\left(\mathrm{cm}^{2}\right)$

active material mass $(\mathrm{g})$

0.00050

electrode thickness ( $\mathrm{C}$ current

collector + active material)

$(\mu \mathrm{m})$

100

current collector mass (g)

0.0025

electrode density $\left(\mathrm{g} / \mathrm{cm}^{3}\right)$

energy density (Wh/Kg of

COF)

energy density $(\mathrm{Wh} / \mathrm{Kg}$ composite $(\mathrm{COF}+$ carbon + binder)

power density (W/Kg of COF)

2175.8

energy density $(\mathrm{W} / \mathrm{Kg}$

composite $(\mathrm{COF}+$ carbon +

binder)

1135.94

Li anode

electrode thickness $(\mathrm{cm})$

0.075

electrode radius $\left(\mathrm{cm}^{2}\right)$

0.714

mass of lithium anode $(\mathrm{g})$

0.064

cell balance (N/P ratio)

5046.7

Electrolyte

electrolyte volume $\left(\mathrm{cm}^{3}\right)$

0.08

electrolyte density $\left(\mathrm{g} / \mathrm{cm}^{3}\right)$

1.26

electrolyte mass $(\mathrm{g})$

0.1008

electrolyte/capacity (g/Ah)

2052.4

Separator

mass (g)

0.0143

mass of coin cell components

Packaging foil

(g)

weight of coin cell $(\mathrm{g})$ 


\begin{tabular}{|c|c|c|}
\hline Cell Component & \multicolumn{2}{|l|}{ Cell Parameters } \\
\hline \multirow[t]{14}{*}{$\begin{array}{l}\text { PEDOT@DAAQ-TFP } \\
\text { COF Cathode }\end{array}$} & $\begin{array}{l}\text { 2nd Discharge Capacity } \\
\text { (mAh/g active material) }\end{array}$ & 62.4 \\
\hline & $\begin{array}{l}\text { Discharge Capacity at } 20 \mathrm{C} \\
\text { (mAh/g active material) }\end{array}$ & 32.1 \\
\hline & active material loading & 0.498 \\
\hline & total coating weight $\left(\mathrm{mg} / \mathrm{cm}^{2}\right)$ & 1.33 \\
\hline & areal capacity $\left(\mathrm{mAh} / \mathrm{cm}^{2}\right)$ & 0.083 \\
\hline & electrode area $\left(\mathrm{cm}^{2}\right)$ & 0.713 \\
\hline & active material mass (g) & 0.00047 \\
\hline & $\begin{array}{l}\text { electrode thickness }(\mathrm{C} \text { current } \\
\text { collector }+ \text { active material }) \\
(\mu \mathrm{m})\end{array}$ & 100 \\
\hline & current collector mass $(\mathrm{g})$ & 0.0025 \\
\hline & electrode density $\left(\mathrm{g} / \mathrm{cm}^{3}\right)$ & 0.484 \\
\hline & $\begin{array}{l}\text { energy density }(\mathrm{Wh} / \mathrm{Kg} \text { of } \\
\text { COF) }\end{array}$ & 137.28 \\
\hline & $\begin{array}{l}\text { energy density }(\mathrm{Wh} / \mathrm{Kg} \\
\text { composite }(\mathrm{COF}+\text { carbon }+ \\
\text { binder) }\end{array}$ & 68.41 \\
\hline & power density (W/Kg of COF) & 1412.4 \\
\hline & $\begin{array}{l}\text { energy density }(\mathrm{W} / \mathrm{Kg} \\
\text { composite }(\mathrm{COF}+\text { carbon }+ \\
\text { binder })\end{array}$ & 703.81 \\
\hline \multirow[t]{4}{*}{ Li anode } & electrode thickness $(\mathrm{cm})$ & 0.075 \\
\hline & electrode radius $\left(\mathrm{cm}^{2}\right)$ & 0.714 \\
\hline & mass of lithium anode (g) & 0.064 \\
\hline & cell balance (N/P ratio) & 8405.6 \\
\hline \multirow[t]{4}{*}{ Electrolyte } & electrolyte volume $\left(\mathrm{cm}^{3}\right)$ & 0.08 \\
\hline & electrolyte density $\left(\mathrm{g} / \mathrm{cm}^{3}\right)$ & 1.26 \\
\hline & electrolyte mass $(\mathrm{g})$ & 0.1008 \\
\hline & electrolyte/capacity (g/Ah) & 3418.5 \\
\hline Separator & $\operatorname{mass}(\mathrm{g})$ & 0.0143 \\
\hline Packaging foil & $\begin{array}{l}\text { mass of coin cell components } \\
(\mathrm{g})\end{array}$ & 2.7218 \\
\hline \multirow[t]{4}{*}{ Cell } & weight of coin cell $(\mathrm{g})$ & 2.904 \\
\hline & voltage $(\mathrm{V})$ & 2.2 \\
\hline & capacity (Ah) & $2.95 \times 10^{-5}$ \\
\hline & energy density $(\mathrm{Wh} / \mathrm{Kg})$ & $2.23 \times 10^{-2}$ \\
\hline
\end{tabular}




\section{XIII.References}

(1) Chong, J. H.; Sauer, M.; Patrick, B. O.; MacLachlan, M. J. Highly stable keto-enamine salicylideneanilines. Org. Lett. 2003, 5, 3823.

(2) Teo, Y. C.; Jin, Z. X.; Xia, Y. Synthesis of Cyclobutadienoid-Fused Phenazines with Strongly Modulated Degrees of Antiaromaticity. Org. Lett. 2018, 20, 3300.

(3) (a) Vitaku, E.; Dichtel, W. R. Synthesis of 2D Imine-Linked Covalent Organic Frameworks through Formal Transimination Reactions. J. Am. Chem. Soc. 2017, 139, 12911; (b) DeBlase, C. R.; Silberstein, K. E.; Truong, T. T.; Abruna, H. D.; Dichtel, W. R. beta-Ketoenamine-Linked Covalent Organic Frameworks Capable of Pseudocapacitive Energy Storage. J. Am. Chem. Soc. 2013, 135, 16821.

(4) Accelrys, 4.4 ed. Accelrys Software, Sand Diego, 2008.

(5) Metropolis, N.; Rosenbluth, A. W.; Rosenbluth, M. N.; Teller, A. H.; Teller, E. J. Chem. Phys. 1953, 21, 1087-1092.

(6) Young, R. A.; Wiles, D. B. J. Appl. Crystallogr. 1982, 15, 430-438.

(7) Pecharsky, V. K.; Zavalij, P. Y. Foundamentals of Powder Diffraction And Structural Characterization of Materials; Springer, 2004; p. 713.

(8) (a) Randles, J. E. A cathode ray polarograph. Part II.-The current-voltage curves. T. Faraday Soc. 1948, 44, 327-338; (b) Ševčik A. Oscillographic polarography with periodical triangular voltage. Collect. of Czech. Chem. C. 1948, 13, 349-377.

(9) Wang, Z.; Li, Y.; Liu, P.; Qi, Q.; Zhang, F.; Lu, G.; Zhao, X.; Huang, X. Few layer covalent organic frameworks with graphene sheets as cathode materials for lithium-ion batteries. Nanoscale, 2019, 11, 5330.

(10) Wang, S.; Wang, Q.; Shao, P.; Han, Y.; Gao, X.; Ma, L.; Yuan, S.; Ma, X.; Zhou, J.; Feng, X.; Wang, B. Exfoliation of covalent organic frameworks into few-layer redox-active nanosheets as cathode materials for lithium-ion batteries. Jour. Am. Chem. Soc. 2017, 139, 4258.

(11) Xu, F.; Jin, S.; Zhong, H.; Wu, D.; Yang, X.; Chen, X.; Wei, H.; Fu, R.; Jiang, D. Electrochemically active, crystalline, mesoporous covalent organic frameworks on carbon nanotubes for synergistic lithiumion battery energy storage. Sci. Rep. 2015, 5, 8225.

(12) Yang, D.; Yao, Z.; Wu, D.; Zhang, Y.; Zhou, Z.; Bu, X. Structure-modulated crystalline covalent organic frameworks as high-rate cathodes for Li-ion batteries. Jour. Mater, Chem. A. 2016, 4(47), 18621.

(13) Luo, Z.; Liu, L.; Ning, J.; Lei, K.; Lu, Y.; Li, F.; Chen, J. A Microporous Covalent-Organic Framework with Abundant Accessible Carbonyl Groups for Lithium-Ion Batteries. Angew. Chem. Int. Ed. 2018, 57, 9443.

(14) Wang, G.; Chandrasekhar, N.; Biswal, B.; Becker, D.; Paasch, S.; Brunner, E.; Addicoat, M.; Yu, M.; Berger, R.; Feng, X. A Crystalline, 2D Polyarylimide Cathode for Ultrastable and Ultrafast Li Storage. Adv. Mater. 2019, 1901478.

(15) Miao, Y.; Hynan, P.; von Jouanne, A.; Yokochi, A. Current Li-ion battery technologies in electric vehicles and opportunities for advancements. Energies 2019, 12, 1074.

(16) Chen, S.; Niu, C.; Lee, H.; Li, Q.; Yu, L.; Xu, W.; Zhang, G.; Dufek, J.; Whittingham, S.; Meng, S.; Xiao, J. Critical Parameters for Evaluating Coin Cells and Pouch Cells of Rechargeable Li-Metal Batteries. Joule, 2019, 3(4), 1094-1105. 